Key Words:

DWPF

CPC, sludge

Retention:

Permanent

\title{
DWPF SB6 INITIAL CPC FLOWSHEEET TESTING SB6-1 TO SB6-6 4L TESTS OF SB6-A AND SB6-B SIMULANTS
}

\author{
D. P. Lambert \\ B. R. Pickenheim \\ D. R. Best
}

JULY 2009

Savannah River National Laboratory

Savannah River Nuclear Solutions

Aiken, SC 29808 


\section{DISCLAIMER}

This work was prepared under an agreement with and funded by the U.S. Government. Neither the U. S. Government or its employees, nor any of its contractors, subcontractors or their employees, makes any express or implied:

1. warranty or assumes any legal liability for the accuracy, completeness, or for the use or results of such use of any information, product, or process disclosed; or

2. representation that such use or results of such use would not infringe privately owned rights; or

3. endorsement or recommendation of any specifically identified commercial product, process, or service.

Any views and opinions of authors expressed in this work do not necessarily state or reflect those of the United States Government, or its contractors, or subcontractors.

Printed in the United States of America

Prepared for

U.S. Department of Energy 
Key Words:

DWPF

CPC, sludge

Retention:

Permanent

\title{
DWPF SB6 INITIAL CPC FLOWSHEEET TESTING SB6-1 TO SB6-6 4L TESTS OF SB6-A AND SB6-B SIMULANTS
}

\author{
D. P. Lambert \\ B. R. Pickenheim \\ D. R. Best
}

JULY 2009

Savannah River National Laboratory

Savannah River Nuclear Solutions

Savannah River Site

Aiken, SC 29808 


\section{TECHNICAL REVIEWS}

\section{AUTHORS:}

D. P. Lambert, Process Technology Programs $\quad$ Date

\begin{tabular}{ll}
\hline B. R. Pickenheim, Process Technology Programs & Date
\end{tabular}

\begin{tabular}{ll}
\hline D. R. Best, Process Technology Programs & Date
\end{tabular}

\section{TECHNICAL REVIEWER:}

M. E. Stone, Process Technology Programs

Date

D. C. Koopman, Process Technology Programs

Date

\section{APPROVERS:}

C. C. Herman, Manager, Process Technology Programs

Date

S. L. Marra, Manager, E\&CPT Research Programs

Date

J. E. Occhipinti, Manager, Waste Solidification Engineering

Date Savannah River Remediation 


\section{TABLE OF CONTENTS}

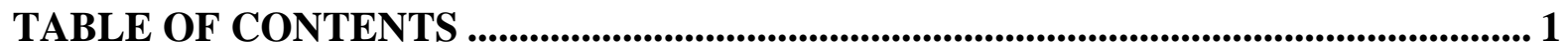

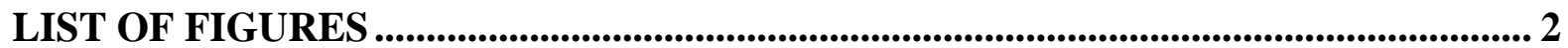

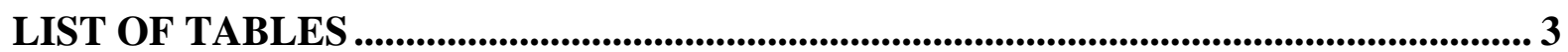

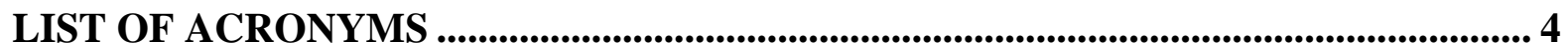

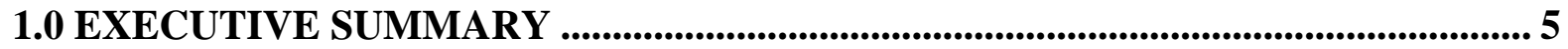

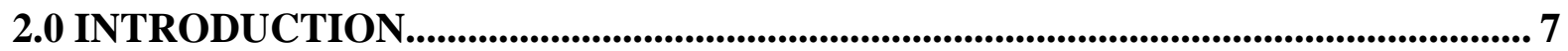

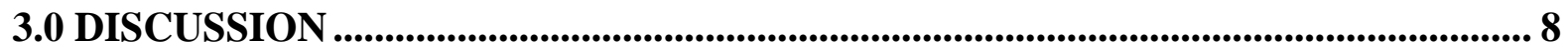

3.1.1 Simulant Preparation............................................................................................. 8

3.1.2 Experimental Apparatus ............................................................................................. 10

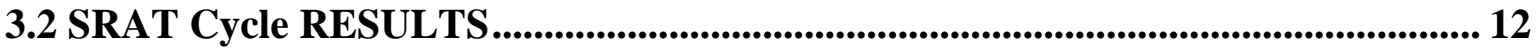

3.3 SRAT Cycle RESULTS........................................................................................... 13

3.3.1 Acid Addition Calculation .......................................................................... 13

3.3.2 Processing Observations ........................................................................................ 18

3.3.3 SRAT Cycle Sample Results........................................................................................ 19

3.3.4 SRAT Cycle Offgas Composition Results ............................................................. 22

3.3.5 SRAT Product Rheological Properties.................................................................. 24

3.4 SME Cycle Results..................................................................................................... 24

3.4.1 Processing Observations .................................................................................................. 25

3.4.2 SME Cycle Sample Results...................................................................................... 25

3.4.3 SME Cycle Offgas Composition Results ............................................................... 26

3.4.4 SME Product Rheological Properties................................................................ 29

3.4.5 Other Notable Observations.......................................................................... 29

4.0 CONCLUSIONS ....................................................................................................... 31

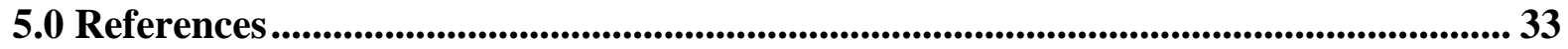

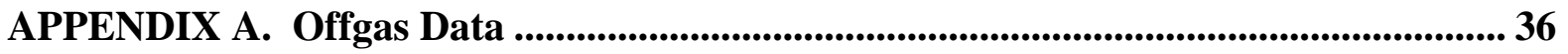

APPENDIX B. Analytical data ................................................................................................... 43

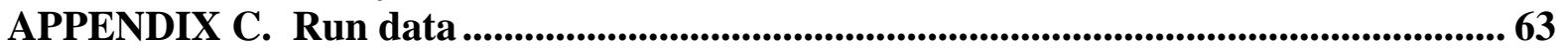




\section{LIST OF FIGURES}

Figure 1. Schematic of SRAT Equipment Set-Up ........................................................... 11

Figure 2. SB6 Flowsheet Testing pH Profiles ...................................................................... 19

Figure 3. Typical SRAT Offgas Profile 120\% Acid Stoichiometry, SB6-A Baseline Sludge

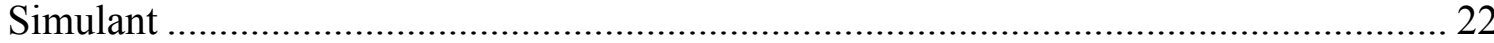

Figure 4. SRAT Cycle Hydrogen Peaks ...................................................................... 23

Figure 5. SME pH Profile from Tests with SB6-A Baseline Sludge Simulant ..................... 25

Figure 6. Typical SME Offgas Profile 120\% Acid Stoichiometry, SB6-A Baseline Sludge

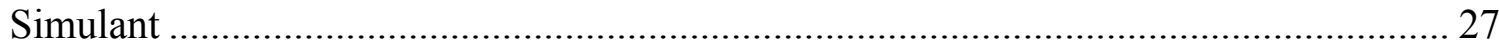

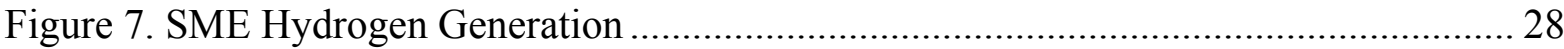

Figure 8. Peak Hydrogen Generation during SME Cycle, SB6-A Baseline Sludge Simulant 28

Figure 9. Photos of SB6-4 Agitator Blades and Shaft (left) and SB6-1 Agitator Blades (right) 


\section{LIST OF TABLES}

Table 1 SB6-A and SB6-B Final Slurry Analyses.......................................................... 8

Table 2 Simulant Composition for SB6 Flowsheet Testing ............................................. 9

Table 3. Trim Chemical Additions, wt \% on Total Solids Basis ....................................... 10

Table 4 SB6-A Baseline Sludge Simulant SRAT/SME Tests .......................................... 13

Table 5 SB6-B Sludge Simulant (One Less Wash) SRAT Tests....................................... 13

Table 6 Acid Calculation Results at 100\% Stoichiometry............................................. 15

Table 7. Conversion of Minimum Koopman Stoichiometry into Hsu Stoichiometry............ 16

Table 8 SRAT Cycle Processing Parameters and Assumptions ........................................ 16

Table 9 SME Processing Parameters and Assumptions ............................................... 17

Table 10 Selected Process Values for Testing with SB6-A Baseline Sludge Simulant ........ 17

Table 11 Selected Process Values for Testing with SB6-B Sludge Simulant (One Less Wash)

Table 12 SRAT Product Anion Concentration from Tests with SB6-A Baseline Sludge

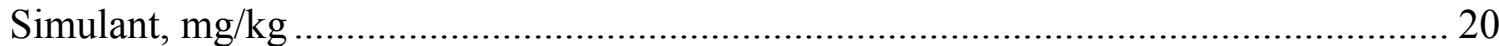

Table 13 SRAT Product Anion Concentration from Tests with SB6-B Sludge Simulant (One

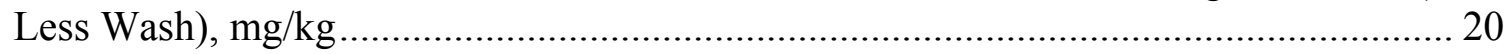

Table 14 SRAT Anion Conversions from Tests with SB6-A Baseline Sludge Simulant .... 20

Table 15 SRAT Product Anion Conversions from Tests with SB6-B Sludge Simulant (One

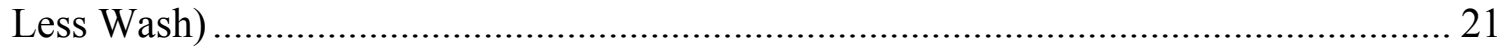

Table 16 SRAT Product Mercury Results from Tests with SB6-A Baseline Sludge Simulant

Table 17 SRAT Product Mercury Results from Tests with SB6-B Sludge Simulant (One

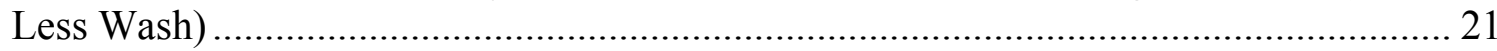

Table 18 SRAT Cycle Hydrogen Peak Generation Rate ................................................. 23

Table 19 SRAT Cycle Nitrous Oxide and Carbon Dioxide Peak Generation Rates from Tests with SB6-A Baseline Sludge Simulant ........................................................................ 24

Table 20 SRAT Cycle Nitrous Oxide and Carbon Dioxide Peak Generation Rates from Tests with SB6-B Sludge Simulant (One Less Wash) ........................................................... 24

Table 21 SRAT Product Rheological Properties with SB6-A Baseline Sludge Simulant..... 24

Table 22 SME Product Results from Tests with SB6-A Baseline Sludge Simulant ............ 26

Table 23 SME Product Anion Conversions from Tests with SB6-A Baseline Sludge

Simulant ......................................................................................................... 26

Table 24 SME Cycle Hydrogen Peak Generation Rate, SB6-A Baseline Sludge Simulant.. 29

Table 25 SME Cycle Nitrous Oxide and Carbon Dioxide Peak Generation Rates from Tests with SB6-A Baseline Sludge Simulant ................................................................ 29

Table 26 SME Product Rheological Properties from Tests with SB6-A Baseline Sludge

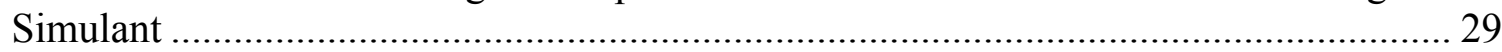

Table 27. Offgas Peak Summary - SB6-A Baseline Sludge Simulant............................... 31

Table 28. Offgas Peak Summary - SB6-B Sludge Simulant (One Less Wash) ................... 32 


\section{LIST OF ACRONYMS}

Aiken County Technology Laboratory

Analytical Development

Chemical Process Cell

Continuous Stirred Tank Reactor

Defense Waste Processing Facility

Formic Acid Vent Condenser

Mercury Water Wash Tank

Process Science Analytical Laboratory

Reduction/Oxidation Potential

Sludge Batch 5

Sludge Batch 6

Sludge Receipt and Adjustment Tank

Slurry Mix Evaporator Condensate Tank

Slurry Mix Evaporator

Task Technical and Quality Assurance Plan

Technical Task Request
ACTL

$\mathrm{AD}$

CPC

CSTR

DWPF

FAVC

MWWT

PSAL

REDOX

SB5

SB6

SRAT

SMECT

SME

TT\&QAP

TTR 


\subsection{EXECUTIVE SUMMARY}

The Defense Waste Processing Facility (DWPF) will transition from Sludge Batch 5 (SB5) processing to Sludge Batch 6 (SB6) processing late in fiscal year 2010. Tests were conducted using non-radioactive simulants of the expected SB6 composition to determine the impact of varying the acid stoichiometry during the Sludge Receipt and Adjustment Tank (SRAT) and Slurry Mix Evaporator (SME) processes. The work was conducted to meet the Technical Task Request (TTR) HLW/DWPF/TTR-2008-0043 ${ }^{1}$, Rev.0 and followed the guidelines of a Task Technical and Quality Assurance Plan² (TT\&QAP).

The flowsheet studies are performed to evaluate the potential chemical processing issues, hydrogen generation rates, and process slurry rheological properties as a function of acid stoichiometry. These studies were conducted with the estimated SB6 composition at the time of the study. This composition assumed a blend of $101,085 \mathrm{~kg}$ of Tank 4 insoluble solids and $179,000 \mathrm{~kg}$ of Tank 12 insoluble solids. For Tank 12, the assumption was that aluminum dissolution would be performed in Tank 51 to dissolve $75 \%$ of the aluminum. ${ }^{3}$

Six DWPF process simulations were completed in 4-L laboratory-scale equipment using two projections of the SB6 blend simulant composition ${ }^{4}$ (Tank 40 composition after Tank 51 transfer on a 40" Tank 40 heel is complete). The more washed simulant (SB6-A washed to nominally $1 \mathrm{M} \mathrm{Na}$ ) had a set of four SRAT and SME simulations at varying acid stoichiometry levels $(90 \%, 100 \%, 120 \%$ and $150 \%)$. Two additional SRAT simulations were made using SB6-B blend simulant (nominally $1.2 \mathrm{M} \mathrm{Na}$ ) at $100 \%$ and $120 \%$ of acid stoichiometry. Acid predictions used the Koopman Acid Prediction Calculation, which was approximately $3 \%$ higher than the Hsu equation. ${ }^{5}$

Two SB6 processing issues were noted during testing. First, the highest hydrogen generation rate exceeded the DWPF SME hydrogen processing limit of $0.223 \mathrm{lb} / \mathrm{hr}$ in Run SB6-4, the highest acid stoichiometry (150\%) experiment. Also, in the lower acid runs $(90 \%$ and $100 \%$ ), the SRAT product mercury concentration exceeded the $0.45 \mathrm{wt} \% \mathrm{Hg}$ in the total solids DWPF SRAT limit after 12 hours of total boiling time.

Processing of SB6B was very similar to SB6-A, but acid requirements were higher due to the higher concentrations of hydroxide, nitrite, and carbonate.

The yield stress of the SRAT and SME products produced during the testing was very low, and some products were below the DWPF process limits. It should be noted that simulants have been indicated lower yield stress than actual waste during past runs and it is not known how the SB6 simulants compare to the real waste. Yield stress can be increased by targeting high solids content, therefore no processing issues are expected from the low yield stresses noted during the testing.

A black film was formed on the agitator shaft and impellers during SB6-4. This run had the highest acid stoichiometry tested and exceeded the hydrogen limits during SME processing. The film was resistant to rinsing, was not removed by soaking in nitric acid and required 
mechanical cleaning to remove. The material deposited on the shaft contained mercury and likely contained noble metals, but speciation was not performed.

The following information was requested as part of the TTR.

\section{Hydrogen and nitrous oxide generation rates as a function of acid stoichiometry}

Hydrogen generation was significantly impacted by the changes in acid stoichiometry from $90 \%$ to $150 \%$ (1.96 to 2.73 moles acid per liter of SB6-A sludge or 1.28 to 1.79 moles acid per liter of SB6-B sludge). For the SB6-A sludge, the hydrogen generation rate exceeded the process limit during the SME cycle at the highest acid stoichiometry (150\%). The nitrous oxide generation peak was relatively insensitive to acid stoichiometry and was relatively low due to the low starting nitrite concentration.

\section{Acid quantities and processing times required for mercury removal}

Mercury was added to the sludge simulant at the start of the SRAT cycle as mercuric oxide at $1.5 \mathrm{wt} \%$ (total solids basis) based on the expected composition of the SB6 blend. Boiling flux was maintained at a scaled rate of $5,000 \mathrm{lb} / \mathrm{hr}$ for a total of 12 hours, so a total of 60,000 $\mathrm{lb}$ of steam flow in DWPF would be needed to remove this same $120 \mathrm{lb}$ of mercury. Acid quantities from $120 \%$ to $150 \%$ resulted in satisfactory mercury removal (product mercury below the 0.45 wt \% SRAT limit) with 12 hours of boiling time. However, the lower acid stoichiometry runs (90\% and $100 \%$ acid stoichiometry) with both the SB6-A and SB6-B simulants resulted in unsatisfactory mercury removal with 12 hours of boiling. If DWPF experiences problems stripping mercury, increasing the acid stoichiometry or boiling time is likely to improve mercury removal but may increase hydrogen generation. Longer boiling times will be used in future SB6 testing to ensure the mercury concentration is below the SRAT limit.

\section{Acid quantities and processing times required for nitrite destruction}

Acid quantities from $100 \%$ to $150 \%$ resulted in satisfactory nitrite destruction with 12 hours of boiling. In all but the $90 \%$ run, the amount of nitrite present in the SRAT product was less than the $1,000 \mathrm{mg} / \mathrm{kg}$ limit. The low starting nitrite concentration helped to reduce the nitrite by the end of the SRAT cycle. Both runs at 100\% stoichiometry met the nitrite limit, but contained some residual nitrite. 


\subsection{INTRODUCTION}

The Defense Waste Processing Facility (DWPF) will transition from Sludge Batch 5 (SB5) processing to Sludge Batch 6 (SB6) processing in late fiscal year 2010. Tests were conducted using non-radioactive simulants of the expected SB6 composition to determine the impact of varying the acid stoichiometry during the Sludge Receipt and Adjustment Tank (SRAT) and Slurry Mix Evaporator (SME) processes. The work was conducted to meet the Technical Task Request (TTR) HLW/DWPF/TTR-2008-00436 ${ }^{6}$, Rev.0 and followed the guidelines of a Task Technical and Quality Assurance Plan (TT\&QAP).

The flowsheet studies are performed to evaluate the potential chemical processing issues, hydrogen generation rates, and process slurry rheological properties as a function of acid stoichiometry. These studies were conducted with the estimated SB6 composition at the time of the study. This composition assumed a blend of $101,085 \mathrm{~kg}$ of Tank 4 insoluble solids and $179,000 \mathrm{~kg}$ of Tank 12 insoluble solids. The current plans are to subject Tank 12 sludge to aluminum dissolution. Liquid Waste Operations assumed that $75 \%$ of the aluminum would be dissolved during this process. After dissolution and blending of Tank 4 sludge slurry, plans included washing the contents of Tank 51 to $\sim 1 \mathrm{M} \mathrm{Na}$. After the completion of washing, the plan assumes that 40 " on Tank 40 slurry would remain for blending with the qualified SB6 material.

There are several parameters that are noteworthy concerning SB6 sludge:

- This is the second batch DWPF will be processing that contains sludge that has had a significant fraction of aluminum removed through aluminum dissolution.

- The sludge is high in mercury, but the projected concentration is lower than SB5.

- The sludge is high in noble metals, but the projected concentrations are lower than SB5

- The sludge is high in $\mathrm{U}$ and $\mathrm{Pu}$ - components that are not added in sludge simulants.

Six DWPF process simulations were completed in 4-L laboratory-scale equipment using two projections of the SB6 blend simulant composition (Tank 40 simulant after Tank 51 transfer is complete). The more washed simulant (SB6-A) had a set of four SRAT and SME simulations at varying acid stoichiometry levels (90\%, 100\%, 120\% and 150\%) using the Koopman Acid Prediction Calculation. Two additional SRAT simulations were made using SB6-B blend simulant at $100 \%$ and $120 \%$ of acid stoichiometry. SME cycles were noted performed for the SB6B simulants to allow the SRAT products to be used for melt rate testing. 


\subsection{DISCUSSION}

Four SRAT/SME runs (SB6-1,2,3, and 4) were completed during this study using acid stoichiometries of $90 \%, 100 \%, 120 \%$, and $150 \%$ with the Tank 40 blend simulant (SB6-A). Two SRAT runs (SB6-5, 6) were completed with the Tank 40 blend simulant (SB6-B) based on Variation 8, with one less wash/decant. These runs were completed and samples analyzed using the practices and procedures typical for Chemical Process Cell (CPC) simulations at the Aiken County Technology Laboratory (ACTL), as described below.

\subsubsection{Simulant Preparation}

Two simulant batches were prepared, one simulating the best estimate of the SB6 Tank 40 composition (SB6-A baseline sludge simulant) and the other simulating one of the processing options with one less wash/decant (SB6-B sludge simulant, one less wash). The SB6-A baseline sludge simulant used targets specified by Jeff Gillam, and David Larsen. Since the insoluble solids in both simulants were very similar, the same insoluble solids basis was used to prepare both simulants. Compositions of the simulants are shown in Table $1^{7}$.

Table 1 SB6-A and SB6-B Final Slurry Targets

\begin{tabular}{|l||c|c|}
\hline \multicolumn{1}{|c|}{ Component } & SB6-A & SB6-B \\
\hline \hline Total Solids, wt \% & 17.31 & 19.61 \\
\hline Insoluble Solids, wt \% & 12.0 & 12.98 \\
\hline Al, calcined wt \% & 12.9 & 15.28 \\
\hline Fe, calcined wt \% & 16.2 & 18.6 \\
\hline Na, calcined wt \% & 18.6 & 13.9 \\
\hline Mn, calcined wt \% & 6.16 & 6.86 \\
\hline Ni, calcined wt \% & 3.52 & 3.92 \\
\hline Nitrite, $\mathrm{mg} / \mathrm{kg}$ & 14,200 & 14,000 \\
\hline Nitrate, $\mathrm{mg} / \mathrm{kg}$ & 9,800 & 8,830 \\
\hline Sulfate, $\mathrm{mg} / \mathrm{kg}$ & 1,540 & 1,000 \\
\hline Soluble $\mathrm{TIC}, \mathrm{mg} / \mathrm{kg}$ & 525 & 490 \\
\hline
\end{tabular}

The preparation of a simulant for Sludge Batch 6 involved six steps: precipitation of manganese (IV) oxide, caustic precipitation of a metal nitrate solution, addition of sodium carbonate, washing of the precipitated solids, addition of minor insoluble species, and addition of soluble species. The precipitation of metal nitrates to form insoluble oxides and hydroxides was conducted in a Continuous Stirred Tank Reactor (CSTR) and involved generation of a metal nitrate solution followed by precipitation of the metal nitrates through the addition of sodium hydroxide. Following the addition of sodium carbonate, the material was washed then soluble/insoluble species were added. Procedure L29 ITS-00124 " "SRS HLW Sludge Simulant Preparation” was utilized to perform the tests.

The simulants were prepared using facilities at both ACTL and in 735-11A. The $\mathrm{MnO}_{2}$ precipitation, the precipitation in the CSTR and the precipitation of the insoluble carbonate species were each completed in one day. The washing and concentration of the precipitate took approximately three weeks, while the final insoluble and soluble species were added in 
one day. The final slurry was sampled and analyzed at ACTL, the Process Science Analytical Laboratory (PSAL), and by Analytical Development (AD). The results of these analyses are summarized in Table 2 . As can be seen, the results agreed well with the planned targets summarized in Table 1. The SB6 simulants were very thin rheologically, especially because of the low insoluble solids targets

Table 2 Simulant Composition for SB6 Flowsheet Testing

\begin{tabular}{|l|l|l|l|l|l|l|}
\hline Analyses & SB6-A & SB6-B & Analyses & \multicolumn{2}{|l|}{ SB6-A } & SB6-B \\
\hline Elemental & Wt\% calcined solids & Solids Data & \multicolumn{2}{|c|}{ Wt \% } \\
\hline $\mathrm{Al}$ & 15.2 & 14.8 & Total Solids & 17.73 & 19.93 \\
\hline $\mathrm{Ba}$ & 0.216 & 0.216 & Insoluble Solids & 11.10 & 13.37 \\
\hline $\mathrm{Ca}$ & 2.09 & 2.17 & Calcined Solids & 12.95 & 14.72 \\
\hline $\mathrm{Cr}$ & 0.251 & 0.253 & Soluble Solids & 6.63 & 6.56 \\
\hline $\mathrm{Cu}$ & 0.084 & 0.095 & Anions & \multicolumn{2}{|c|}{ mg/kg } \\
\hline $\mathrm{Fe}$ & 18.3 & 18.3 & Chloride & 169 & 191 \\
\hline $\mathrm{K}$ & 0.103 & 0.097 & Nitrite & 14,000 & 13,600 \\
\hline $\mathrm{Mg}$ & 1.50 & 1.56 & Nitrate & 8,710 & 9,040 \\
\hline $\mathrm{Mn}$ & 6.74 & 6.98 & Formate & $<100$ & $<100$ \\
\hline $\mathrm{Na}$ & 14.4 & 15.2 & Sulfate & 1,190 & 1,150 \\
\hline $\mathrm{Ni}$ & 3.85 & 4.02 & Oxalate & $<100$ & $<100$ \\
\hline $\mathrm{P}$ & $<0.100$ & $<0.100$ & Phosphate & $<100$ & $<100$ \\
\hline $\mathrm{Pb}$ & 0.013 & 0.027 & Total Carbonate & 11,900 & 13,000 \\
\hline $\mathrm{S}$ & 0.309 & 0.308 & Other Results & & \\
\hline $\mathrm{Si}$ & 0.502 & 0.598 & Base Equivalents (molar) & 0.620 & 0.732 \\
\hline $\mathrm{Ti}$ & 0.020 & 0.021 & Slurry Density (g/ml) & 1.14 & 1.165 \\
\hline $\mathrm{Zn}$ & 0.155 & 0.155 & pH & 12.7 & 12.7 \\
\hline $\mathrm{Zr}$ & 0.359 & 0.362 & Soluble Total Inorganic C & 2390 & \\
\hline
\end{tabular}

Noble metals, mercury, and rinse water were added to the sludge simulant prior to performing the SRAT cycle. The noble metal concentrations were based on $100 \%$ of the estimated amount in the sludge batch. The concentrations of each trim chemical added are shown in Table 3. Noble Metal Concentrations were based on lanthanum concentration predicted by Ned Bibler using David Larsen's lanthanum estimate with typical fission yield. 
Table 3. Trim Chemical Additions, wt \% on Total Solids Basis

\begin{tabular}{|l|c|c|}
\hline \multicolumn{1}{|c|}{ TRIM CHEMICAL } & SB5 & SB6 \\
\hline Trimmed Sludge Target Ag metal content & 0.0137 & 0.0002 \\
\hline Trimmed Sludge Target wt $\%$ Hg dry basis & 2.38 & 1.50 \\
\hline Trimmed Sludge Target Pd metal content & 0.0036 & 0.0158 \\
\hline Trimmed Sludge Target Rh metal content & 0.0227 & 0.0202 \\
\hline Trimmed Sludge Target Ru metal content & 0.0980 & 0.0760 \\
\hline
\end{tabular}

\subsubsection{Experimental Apparatus}

The testing was performed at the ACTL using the four-liter kettle setup. The SRAT rigs were assembled following the guidelines of SRNL-PSE-2006-00074 ${ }^{9}$. The intent of the equipment is to functionally replicate the DWPF processing vessels. The 4-liter glass kettle is used to replicate both the SRAT and the SME, and it is connected to the SRAT Condenser, the Mercury Water Wash Tank (MWWT), and the Formic Acid Vent Condenser (FAVC). The Slurry Mix Evaporator Condensate Tank (SMECT) is represented by a sampling bottle that is used to remove condensate through the MWWT. For the purposes of this paper, the condensers and wash tank are referred to as the offgas components. A sketch of the experimental setup is given as Figure 1 . 


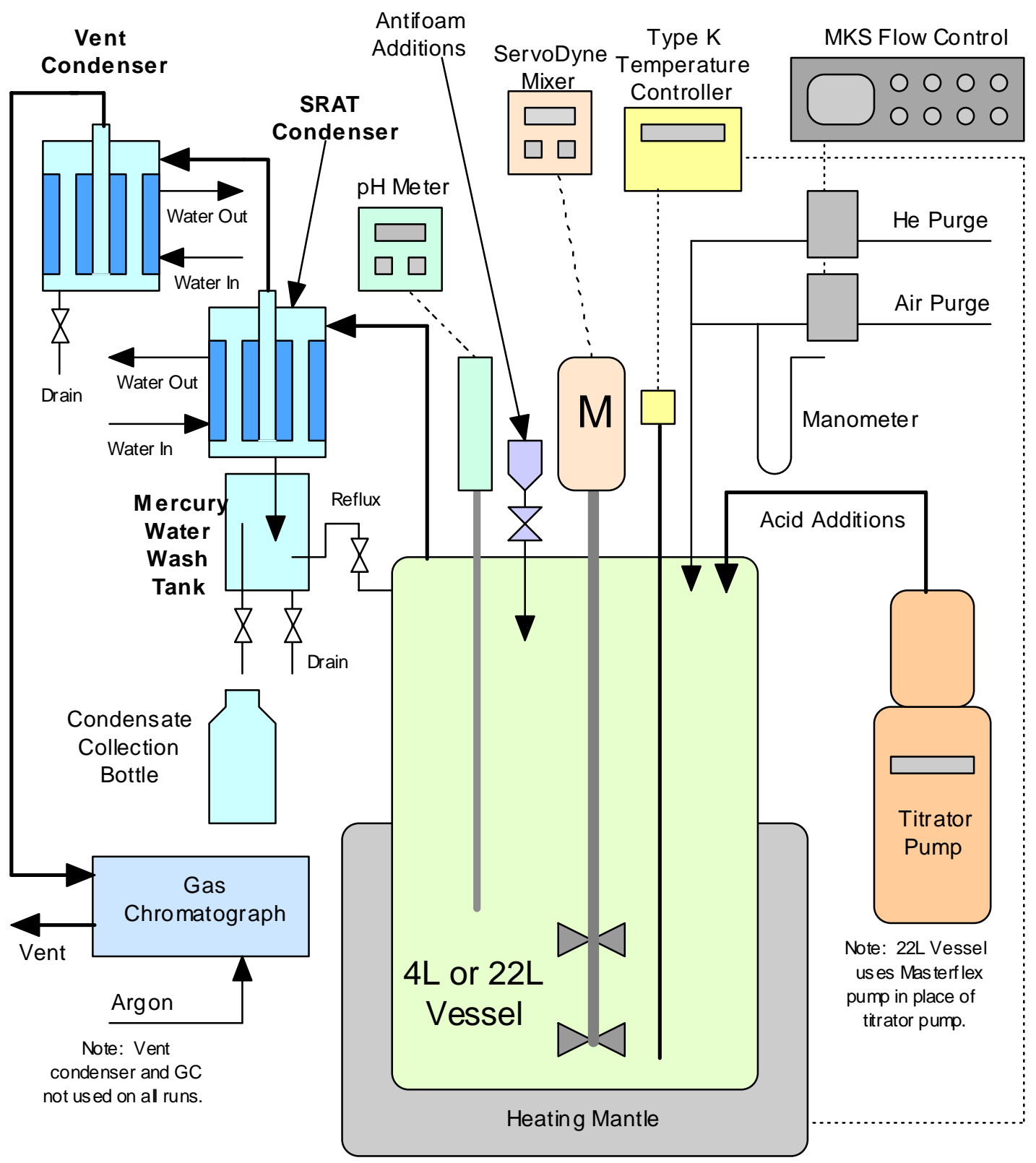

Figure 1. Schematic of SRAT Equipment Set-Up

The flowsheet runs were performed using the guidance of Procedure ITS-0094 ${ }^{10}$ ("Laboratory Scale Chemical Process Cell Simulations") of Manual L29. Offgas hydrogen, oxygen, nitrogen, nitrous oxide, and carbon dioxide concentrations were measured during the experiments using in-line instrumentation. Helium was introduced at a concentration of $0.5 \%$ of the total air purge as an inert tracer gas so that total amounts of generated gas and peak generation rates could be calculated. During the runs, the kettle was monitored to observe reactions that were occurring to include foaming, air entrainment, rheology changes, 
loss of heat transfer capabilities, and offgas carryover. Observations were recorded on data sheets and pasted into a laboratory notebook ${ }^{11}$.

Concentrated nitric acid (50-wt\%) and formic acid (90-wt $\%)$ were used to acidify the sludge and perform neutralization and reduction reactions during processing. The amounts of acid to add for each run were determined using the proposed Koopman DWPF acid addition equation. The split of the acid was determined using the REDOX equation currently being used in DWPF processing ${ }^{12}$. The REDOX target $\left(\mathrm{Fe}^{2+} / \Sigma \mathrm{Fe}\right)$ was 0.2 . To account for the reactions and anion destructions that occur during processing, assumptions about nitrite destruction, nitrite to nitrate conversion, and formate destruction were made for each run.

To prevent foaming during SRAT processing, 200 ppm IIT 747 antifoam was added before acid addition, 100 ppm was added after nitric acid addition was complete and 500 ppm was added at the completion of formic acid addition. SRAT processing included 12-hours at boiling (dewater time plus reflux time). The SME processing did not include the addition of canister dewaters. The frit addition was split into two equal portions. The frit was added with water and formic acid at DWPF prototypical conditions. Concentration was performed after each frit addition and then the vessel was allowed to cool to approximately 90 degrees. An addition of $1 / 2$ of the frit water was made to further cool the vessel, then the frit was added followed by the remaining water.. A final concentration was performed at the end of the run to meet the target total solids of $45 \mathrm{wt} \%$. The SRAT condenser was maintained at $25^{\circ} \mathrm{C}$ during the run, while the vent condenser was maintained at $4^{\circ} \mathrm{C}$.

\subsection{SRAT CYCLE RESULTS}

Four SRAT/SME runs (SB6-1, 2, 3, and 4) were completed during this study using acid stoichiometries of $90 \%, 100 \%, 120 \%$, and $150 \%$ with the Tank 40 blend simulant (SB6-A) as shown in Table 4.. Two SRAT runs (SB6-5, 6) were completed with the Tank 40 blend simulant (SB6-B) using acid stoichiometries of $100 \%$ and $120 \%$ based on Liquid Waste's Variation 8, with one less wash/decant, as shown in Table 5. A unique run number was assigned to each run. All runs targeted a predicted glass REDOX of 0.2 by adjusting the ratio of formic to nitric acid during the SRAT cycle and using the current REDOX equation.

To prevent foaming during SRAT processing, 200 ppm IIT 747 antifoam was added before acid addition, $100 \mathrm{ppm}$ was added after nitric acid addition was complete and $500 \mathrm{ppm}$ was added at the completion of formic acid addition. SRAT processing included 12-hours ${ }^{*}$ at boiling (dewater time plus reflux time). The boiling time calculation represents the minimum expected time that adequate mercury stripping could be expected and was used to allow differences in processing characteristics to be noted.

\footnotetext{
* The minimum boiling time to strip mercury is calculated by using the acid calc spreadsheet, assuming $500 \mathrm{lb}$ steam is required to strip $1 \mathrm{lb}$ elemental mercury with a $5000 \mathrm{lb} / \mathrm{hr}$ steam flowrate for a 6000 gallon sludge batch. This is based on shielded cells mercury stripping data.

Minimum boil time, $\min =($ sludge solids mass $* \mathrm{Hg} \mathrm{wt} \% / 100-S R A T$ product solids mass $* .45 / 100) * 500 \mathrm{~g}$ steam $/ \mathrm{g} \mathrm{Hg} / 4.24 \mathrm{~g}$ steam $/ \mathrm{min}=505.3 \mathrm{~g} * 1.5 \mathrm{~g} \mathrm{Hg} / 100 \mathrm{~g}-585.65 \mathrm{~g} * 0.45 \mathrm{~g} \mathrm{Hg} / 100) * 500 \mathrm{~g} \mathrm{Hg} / 500 \mathrm{~g}$ steam * $4.24 \mathrm{~g}$ steam $/$ minute $=604$ minutes or 10 hours and four minutes.
} 
The SME processing did not include the addition of canister dewaters. The frit addition was split into two equal portions. The frit was added with water and formic acid at DWPF prototypical conditions. Concentration was performed after each frit addition and then heat was removed to allow for the next frit addition A final concentration was performed at the end of the run to meet the target total solids. The SRAT condenser was maintained at $25^{\circ} \mathrm{C}$ during the run, while the vent condenser was maintained at $4^{\circ} \mathrm{C}$.

\subsection{SRAT CYCLE RESULTS}

Four SRAT/SME runs (SB6-1, 2, 3, and 4) were completed during this study using acid stoichiometries of $90 \%, 100 \%, 120 \%$, and $150 \%$ with the Tank 40 blend simulant (SB6-A) as shown in Table 4.. Two SRAT runs $(\mathrm{SB} 6-5,6)$ were completed with the Tank 40 blend simulant (SB6-B) using acid stoichiometries of $100 \%$ and $120 \%$ based on Liquid Waste's Variation 8, with one less wash/decant, as shown in Table 5. A unique run number was assigned to each run. All runs targeted a predicted glass REDOX $\left(\mathrm{Fe}^{2+} / \Sigma \mathrm{Fe}\right)$ of 0.2 by adjusting the ratio of formic to nitric acid during the SRAT cycle and using the current REDOX equation.

Table 4 SB6-A Baseline Sludge Simulant SRAT/SME Tests

\begin{tabular}{|c|c|c|c|c|}
\hline Run Number & Acid Stoichiometry & REDOX Target & Process Frit & Waste Loading \\
\hline SB6-1 & $100 \%$ & 0.2 & 418 & 38 \\
\hline SB6-2 & $90 \%$ & 0.2 & 418 & 38 \\
\hline SB6-3 & $120 \%$ & 0.2 & 418 & 38 \\
\hline SB6-4 & $150 \%$ & 0.2 & 418 & 38 \\
\hline
\end{tabular}

Table 5 SB6-B Sludge Simulant (One Less Wash) SRAT Tests

\begin{tabular}{|l|c|c|}
\hline Run Number & Acid Stoichiometry & $\begin{array}{c}\text { REDOX } \\
\text { Target }\end{array}$ \\
\hline SB6-5 & $100 \%$ & 0.2 \\
\hline SB6-6 & $120 \%$ & 0.2 \\
\hline
\end{tabular}

All six experiments included a SRAT cycle, designed to simulate the chemical processing in the DWPF SRAT. The SRAT cycles were completed using conservative design basis inputs such as acid addition flowrates, air purges, steam flowrates, although these may be different than the typical flowrates used during DWPF SRAT processing.

\subsubsection{Acid Addition Calculation}

An acid calculation was completed prior to each experiment to estimate a number of scaled parameters necessary to complete each experiment at the conditions specified with the inputs such as kettle power (designed to simulate steam flow), acid addition flowrate, offgas purge, acid volume, etc. Results from the acid calculation and other run data are summarized in Appendix C. 


\subsubsection{Calculation Inputs}

The SRAT cycle acid calculation utilizes the amount of nitrite, mercury, manganese, carbonate, and base equivalents to calculate the stoichiometric amount of acid to be added. Nitric acid and formic acid amounts are calculated ${ }^{13}$ based on the applied stoichiometric factor and the ratio needed to achieve the predicted glass REDOX target of $0.2 \mathrm{Fe}^{+2} / \Sigma \mathrm{Fe}$. The equation for prediction of glass REDOX utilizes estimates of the amount of formate, oxalate, nitrate, nitrite, manganese, and total solids in the SME product. The estimation of the final concentration for the anions requires assumptions to be made concerning how these species will react during the SRAT and SME cycles. Formate and oxalate are destroyed by reactions with oxidizing species and by catalytic reactions with noble metals. Nitrite is typically consumed during acid additions, but can react to form different species including nitrate.

Three different acid addition predictions were used. The Hsu equation, an equation with inputs for total base, slurry carbonate, nitrite, manganese and mercury, has been used for estimating the acid requirement in DWPF since startup. Two new acid equations, which more accurately predict the acid requirement in DWPF, have been developed. The Koopman equation adds inputs for supernate (not slurry) carbonate, calcium and magnesium to better predict the acid requirement. The cation equation uses cations (manganese, sodium, potassium, mercury, cesium, strontium, calcium, nickel, and magnesium) to predict the acid demand with credits for anions (nitrite, nitrate, sulfate, chloride, formate and phosphate). Both of these new equations were developed for minimum acid (just enough acid to destroy nitrite with very little hydrogen generation) and nominal acid (enough acid to destroy nitrite, reduce mercury, and without making too much hydrogen). The minimum Koopman equation's prediction of acid requirement was used throughout the testing and the other results are summarized in Table 6. The acid calculation inputs and assumptions are shown in Table 8 and Table 9 for runs SB6-1 to SB6-6. The same assumptions and inputs were used for all runs, with the exception of the acid stoichiometry. Conversion of minimum Koopman stoichiometric factors into the equivalent Hsu equation stoichiometry is shown in 
Table 7. Note that the conversion of SB6A and SB6B shiochiometry results in the same factors for these sludges, but this is not expected to be the same for all sludges.

Table 6 Acid Calculation Results at $\mathbf{1 0 0 \%}$ Stoichiometry

\begin{tabular}{|l|l|l|}
\hline Equation & SB6-A & SB6-B \\
\hline Hsu Equation, M & 1.56 & 1.77 \\
\hline Minimum Koopman, M & 1.61 & 1.83 \\
\hline Nominal Koopman, M & 1.96 & 2.24 \\
\hline Minimum Cation, M & 1.29 & 1.62 \\
\hline Nominal Cation, M & 1.56 & 1.95 \\
\hline
\end{tabular}


Table 7. Conversion of Minimum Koopman Stoichiometry into Hsu Stoichiometry

\begin{tabular}{|c|c|c|}
\hline $\begin{array}{c}\text { Minimum } \\
\text { Koopman } \\
\text { Stoichiometric } \\
\text { Factor }\end{array}$ & $\begin{array}{c}\text { Hsu Equivalent } \\
\text { Stoichiometry }\end{array}$ & $\begin{array}{c}\text { Nominal } \\
\text { Koopman } \\
\text { Stochiometry }\end{array}$ \\
\hline 90 & 93 & 74 \\
\hline 100 & 103 & 82 \\
\hline 120 & 124 & 99 \\
\hline 150 & 155 & 123 \\
\hline
\end{tabular}

Table 8 SRAT Cycle Processing Parameters and Assumptions

\begin{tabular}{|c|c|c|c|}
\hline Description & \multirow[t]{2}{*}{ Units } & $\begin{array}{c}\text { SB6- } \\
1,2,3,4\end{array}$ & $\begin{array}{c}\text { SB6- } \\
5,6\end{array}$ \\
\hline Sludge & & $\begin{array}{c}\text { SB6-A } \\
\text { Baseline }\end{array}$ & $\begin{array}{c}\text { SB6-B } \\
\text { One } \\
\text { Less } \\
\text { Wash }\end{array}$ \\
\hline Conversion of Nitrite to Nitrate in SRAT Cycle & gmol $\mathrm{NO}_{3}^{-} / 100 \mathrm{gmol} \mathrm{NO}_{2}^{-}$ & 20.00 & 20.00 \\
\hline Destruction of Nitrite in SRAT and SME cycle & $\%$ of starting nitrite & 100.00 & 100.00 \\
\hline Destruction of Formic acid charged in SRAT & $\%$ & 20.00 & 20.00 \\
\hline Destruction of oxalate charged & $\%$ & 100.00 & 100.00 \\
\hline Percent Acid in Excess Stoichiometric Ratio & $\%$ & 100.00 & 100.00 \\
\hline SRAT Product Target Solids & $\%$ & 25.00 & 25.00 \\
\hline Nitric Acid Molarity & Molar & 10.534 & 10.534 \\
\hline Formic Acid Molarity & Molar & 23.600 & 23.600 \\
\hline Scaled Nitric Acid addition Rate & gallons per minute & 2.0 & 2.0 \\
\hline Scaled Formic Acid addition Rate & gallons per minute & 2.0 & 2.0 \\
\hline REDOX Target & $\mathrm{Fe}^{+2} / \Sigma \mathrm{Fe}$ & 0.200 & 0.200 \\
\hline Trimmed Sludge Target Ag metal content & total wt $\%$ dry basis & 0.0002 & 0.0002 \\
\hline Trimmed Sludge Target wt $\%$ Hg dry basis & total $\mathrm{wt} \%$ dry basis & 1.5000 & 1.5000 \\
\hline Trimmed Sludge Target Pd metal content & total $\mathrm{wt} \%$ dry basis & 0.0158 & 0.0158 \\
\hline Trimmed Sludge Target $\mathrm{Rh}$ metal content & total $\mathrm{wt} \%$ dry basis & 0.0202 & 0.0202 \\
\hline Trimmed Sludge Target Ru metal content & total wt $\%$ dry basis & 0.0760 & 0.0760 \\
\hline Water to dilute fresh sludge and/or rinse trim chemicals & $\mathrm{g}$ & 50 & 50 \\
\hline Mass of SRAT cycle samples & $\mathrm{g}$ & 250 & 250 \\
\hline Wt $\%$ Active Agent In Antifoam Solution & $\%$ & 10 & 10 \\
\hline $\begin{array}{l}\text { Basis Antifoam Addition for SRAT (generally } 100 \mathrm{mg} \\
\text { antifoam/kg slurry) }\end{array}$ & $\mathrm{mg} / \mathrm{kg}$ slurry & 100 & 100 \\
\hline Number of basis antifoam additions added during SRAT & & 8 & 8 \\
\hline
\end{tabular}


Table 9 SME Processing Parameters and Assumptions

\begin{tabular}{|c|c|c|}
\hline Description & Units & $\begin{array}{c}\text { SB6- } \\
1,2,3,4\end{array}$ \\
\hline \multicolumn{2}{|l|}{ Sludge } & $\begin{array}{l}\text { SB6-A } \\
\text { Blend }\end{array}$ \\
\hline \multicolumn{2}{|l|}{ Frit type } & 418 \\
\hline Destruction of Formic acid in SME & $\%$ & 10.00 \\
\hline Destruction of Nitrate in SME & $\%$ & 10.00 \\
\hline Assumed SME density & $\mathrm{kg} / \mathrm{L}$ & 1.450 \\
\hline Basis Antifoam Addition for SME cycle & $\mathrm{mg} / \mathrm{kg}$ slurry & 100 \\
\hline \multicolumn{2}{|c|}{ Number of basis antifoam additions added during SME cycle } & 5 \\
\hline Sludge Oxide Contribution in SME (Waste Loading) & $\%$ & 38 \\
\hline Frit Slurry Formic Acid Ratio & g $90 \mathrm{wt} \%$ FA/100 g Frit & 1.50 \\
\hline Target SME Solids total $\mathrm{Wt} \%$ & $\mathrm{wt} \%$ & 45.0 \\
\hline \multicolumn{2}{|l|}{ Number of frit additions in SME Cycle } & 2 \\
\hline
\end{tabular}

\subsubsection{Acid Calculation Results}

The acid calculation determines the values for a large number of processing parameters as well as the amount of formic and nitric acid to be used. Selected values are shown in Table 10 and Table 11. The stoichiometric acid addition for the sludge simulant was calculated to be 1.61 moles per liter for SB6-A and 1.83 moles per liter for SB6-B. The minimum stoichiometric acid requirement is based on a new acid addition equation developed by David Koopman. As acid stoichiometry increased, the ratio of formic acid to the total amount of acid decreased. This decrease is due to the presence of nitrate and nitrite in the initial sludge simulant lowering the amount of nitrate or oxidizers needed to balance the formic acid at lower acid stoichiometries. The frit addition increased slightly due to the process samples being more dilute in terms of the original feed as acid stoichiometry increased.

Table 10 Selected Process Values for Testing with SB6-A Baseline Sludge Simulant

\begin{tabular}{|c|c|c|c|}
\hline $\begin{array}{c}\text { Acid } \\
\text { Stoichiometry }\end{array}$ & $\begin{array}{c}\text { Total Acid } \\
\text { Required } \\
\text { (mol/L) }\end{array}$ & $\begin{array}{c}\text { Formic Acid Ratio } \\
\text { (\% of Total Acid) }\end{array}$ & $\begin{array}{c}\text { Frit Addition } \\
\text { Amount (grams) }\end{array}$ \\
\hline $90 \%$ & 1.45 & 88.4 & 537.7 \\
\hline $100 \%$ & 1.61 & 87.1 & 539.7 \\
\hline $120 \%$ & 1.93 & 85.2 & 543.3 \\
\hline $150 \%$ & 2.42 & 83.2 & 548.1 \\
\hline
\end{tabular}


Table 11 Selected Process Values for Testing with SB6-B Sludge Simulant (One Less Wash)

\begin{tabular}{|c|c|c|c|}
\hline $\begin{array}{c}\text { Acid } \\
\text { Stoichiometry }\end{array}$ & $\begin{array}{c}\text { Total Acid } \\
\text { Required } \\
\text { (mol/L) }\end{array}$ & $\begin{array}{c}\text { Formic Acid Ratio } \\
\text { (\% of TOTAL } \\
\text { ACID) }\end{array}$ & $\begin{array}{c}\text { Calculated Frit } \\
\text { Addition } \\
\text { Amount (grams) }\end{array}$ \\
\hline $100 \%$ & 1.83 & 87.5 & 558.5 \\
\hline $120 \%$ & 2.20 & 85.5 & 549.1 \\
\hline
\end{tabular}

\subsubsection{Processing Observations}

Overall processing during the testing went smoothly with no interruptions or upsets occurring during process runs. The sludge became less viscous during acid additions and no problems were noted with mixing during the runs. Agitator speeds of $250 \mathrm{RPM}^{\dagger}$ were sufficient to mix the sludge simulants.

\subsubsection{Foaming}

No additional antifoam was required during any of the nine experiments. No foaming problems were noted during SRAT or SME processing.

\subsubsection{2 pH Profiles}

The $\mathrm{pH}$ profiles of the four SB6-A runs in general matched profiles noted during previous $\mathrm{CPC}$ simulations ${ }^{14}$. As shown in Figure 2, the $\mathrm{pH}$ was lower for runs with higher acid additions. Formic acid decomposition during high acid runs can result in lower $\mathrm{pH}$ at higher acid stoichiometries, but the decomposition noted during the flowsheet testing was not high enough to raise the $\mathrm{pH}$ of the higher acid runs above the lower acid runs in the SRAT cycle. All three runs with acid stoichiometries above $100 \%$ had a minimum $\mathrm{pH}$ near 4.0 at the end of acid addition. The $\mathrm{pH}$ profiles for runs with SB6B were very similar.

\footnotetext{
$\dagger$ The mixing geometry of the lab-scale apparatus is not prototypic of the DWPF SRAT/SME vessels and mixing was adjusted as required during testing to ensure that the process chemistry was captured. Agitator speed is reported only to give an indication of changes in rheological properties during the testing.
} 


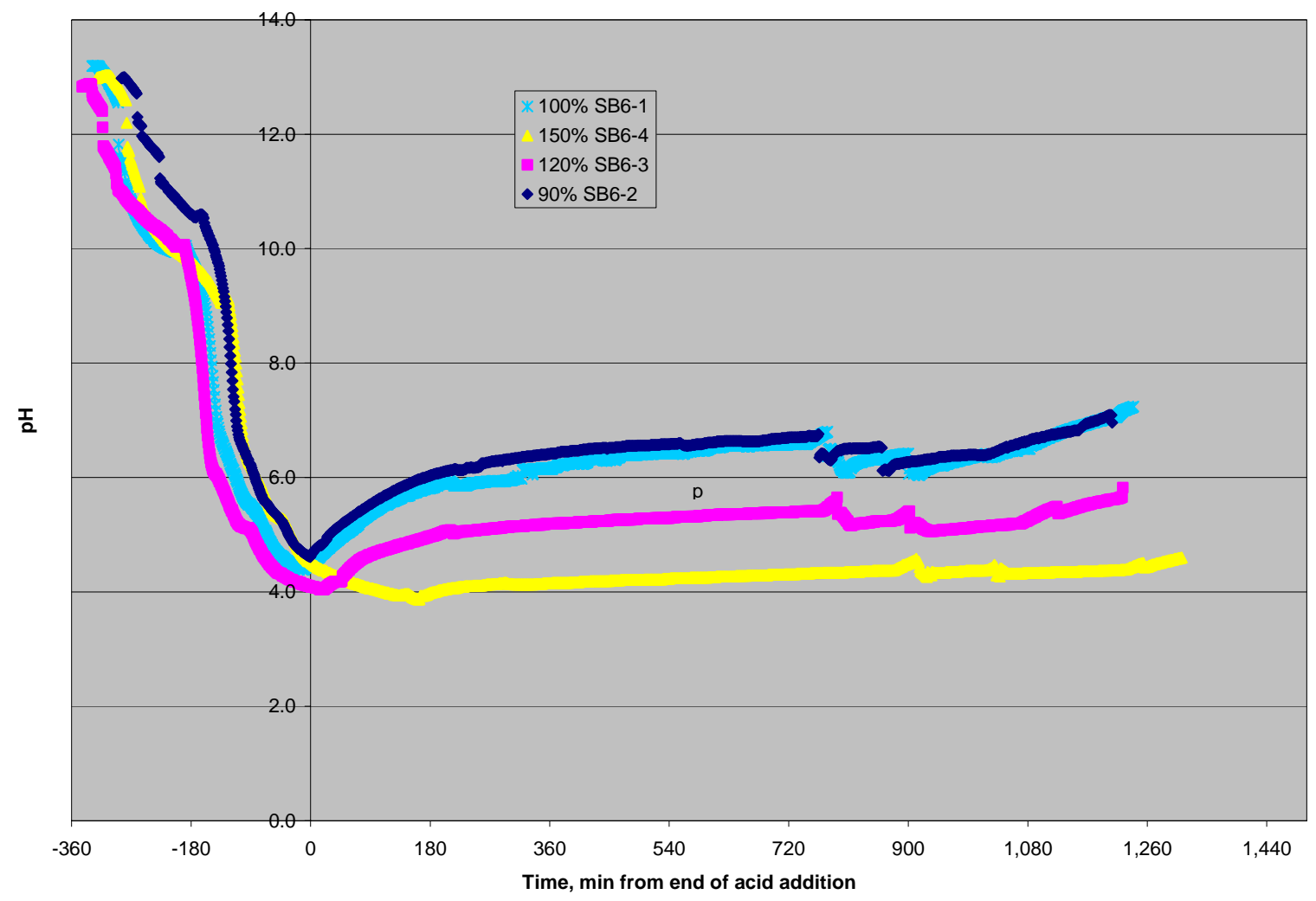

Figure 2. SB6 Flowsheet Testing pH Profiles

\subsubsection{SRAT Cycle Sample Results}

Samples were pulled at the conclusion of the SRAT cycle. The total solids, mercury, anions, and soluble elemental species were analyzed for all samples. Samples were taken of the SRAT dewater and the MWWT contents at the completion of the SRAT cycle. All sample results are tabulated in Appendix B.

\subsubsection{Nitrite, Nitrate, Formate}

Nitrite destruction met the process requirement of $<1000 \mathrm{mg} / \mathrm{kg}$ at the end of the SRAT cycle for all runs except the $90 \%$ stoichiometry run. For runs at $120 \%$ stoichiometry $(100 \%$ nominal Koopman) or higher, there was no detectable nitrite at the end of the SRAT cycle. Note that the total time at boiling was 12 hours for each of these experiments. Anion results are summarized in Table 12 and Table 13. 
Table 12 SRAT Product Anion Concentration from Tests with SB6-A Baseline Sludge Simulant, $\mathbf{m g} / \mathbf{k g}$

\begin{tabular}{|l|c|c|c|c|c|c|c|c|}
\hline $\begin{array}{c}\text { ACID } \\
\text { STOICHIOMETRY }\end{array}$ & $\begin{array}{c}\text { Sample } \\
\text { \#09- }\end{array}$ & $\mathbf{F}$ & $\mathbf{C l}$ & $\mathbf{N O}_{\mathbf{2}}$ & $\mathbf{N O}_{\mathbf{3}}$ & $\mathbf{S O}_{\mathbf{4}}$ & $\mathbf{P O}_{\mathbf{4}}$ & $\mathbf{H C O}_{\mathbf{2}}$ \\
\hline $90 \%$ SB6-2 & SB6-2-2711 & $<100$ & 360 & 1960 & 24,600 & $<100$ & $<100$ & 52,600 \\
\hline $100 \%$ SB6-1 & SB6-1-2677 & $<100$ & 393 & 200 & 27,000 & $<100$ & $<100$ & 54,600 \\
\hline $120 \%$ SB6-3 & SB6-3-2719 & $<100$ & 349 & $<100$ & 31,900 & 801 & $<100$ & 57,600 \\
\hline $150 \%$ SB6-4 & SB6-4-2694 & $<100$ & 335 & $<100$ & 37,700 & 256 & $<100$ & 67,000 \\
\hline
\end{tabular}

Table 13 SRAT Product Anion Concentration from Tests with SB6-B Sludge Simulant (One Less Wash), mg/kg

\begin{tabular}{|l|l|c|c|c|c|c|c|c|}
\hline $\begin{array}{c}\text { ACID } \\
\text { STOICHIOMETRY }\end{array}$ & Sample \#09- & $\mathbf{F}$ & $\mathbf{C l}$ & $\mathbf{N O}_{\mathbf{2}}$ & $\mathbf{N O}_{\mathbf{3}}$ & $\mathbf{S O}_{\mathbf{4}}$ & $\mathbf{P O}_{\mathbf{4}}$ & $\mathbf{H C O}_{\mathbf{2}}$ \\
\hline $100 \%$ & SB6-5-2748 & $<100$ & 362 & 518 & 24,200 & $<100$ & $<100$ & 52,400 \\
\hline $120 \%$ & SB6-6-2765 & $<100$ & 331 & $<100$ & 29,300 & $<100$ & $<100$ & 56,900 \\
\hline
\end{tabular}

In a "typical run", approximately one-third of the nitrite is converted to nitrate and the other two-thirds are converted to $\mathrm{NO}_{\mathrm{x}}$ and $\mathrm{N}_{2} \mathrm{O}$. In all of these runs (Table 14 and Table 15), some additional nitrate was present in the SRAT product due to the destruction of nitrite.

Formate is destroyed by reduction of $\mathrm{Mn}, \mathrm{Hg}$ and catalytic destruction of nitrite ion to primarily produce $\mathrm{NO}, \mathrm{N}_{2} \mathrm{O}, \mathrm{NO}_{2}$, and $\mathrm{CO}_{2}$. Formic acid is destroyed catalytically to produce primarily $\mathrm{CO}_{2}$, and hydrogen. An overall trend of higher formate loss with higher acid stoichiometry is indicated, which matches previous results and the amount of formate loss is consistent with previous testing.

Table 14 SRAT Anion Conversions from Tests with SB6-A Baseline Sludge Simulant

\begin{tabular}{|l|c|c|c|}
\hline \multirow{2}{*}{$\begin{array}{c}\text { ACID } \\
\text { STOICHIOMETRY }\end{array}$} & \multicolumn{3}{|c|}{ SRAT CYCLE } \\
\cline { 2 - 4 } & Formate & $\begin{array}{c}\text { Nitrite to } \\
\text { Nitrate } \\
\text { Conversion }\end{array}$ & $\begin{array}{c}\text { Nitrite } \\
\text { Destruction }\end{array}$ \\
\hline SB6-2 90\% & $16.7 \%$ & $10.5 \%$ & $88.8 \%$ \\
\hline SB6-1 100\% & $18.3 \%$ & $11.9 \%$ & $98.8 \%$ \\
\hline SB6-3 120\% & $22.3 \%$ & $18.7 \%$ & $100 \%$ \\
\hline SB6-4 150\% & $19.8 \%$ & $26.1 \%$ & $100 \%$ \\
\hline
\end{tabular}


Table 15 SRAT Product Anion Conversions from Tests with SB6-B Sludge Simulant (One Less Wash)

\begin{tabular}{|l|c|c|c|}
\hline \multirow{2}{*}{$\begin{array}{l}\text { ACID } \\
\text { STOICHIOMETRY }\end{array}$} & \multicolumn{3}{|c|}{ SRAT CYCLE } \\
\cline { 2 - 4 } & $\begin{array}{c}\text { Formate } \\
\text { Destruction }\end{array}$ & $\begin{array}{c}\text { Nitrite to } \\
\text { Nitrate } \\
\text { Conversion }\end{array}$ & $\begin{array}{c}\text { Nitrite } \\
\text { Destruction }\end{array}$ \\
\hline SB6-5 100\% & $22.4 \%$ & $5.4 \%$ & $96.5 \%$ \\
\hline SB6-6 $120 \%$ & $24.4 \%$ & $12.6 \%$ & $100 \%$ \\
\hline
\end{tabular}

\subsubsection{Mercury}

The SRAT product samples were analyzed for mercury content to evaluate the stripping of mercury during the SRAT cycle. The SRAT product must be below $0.45 \mathrm{wt} \%$ (solids basis) mercury to meet process specifications. Sludge batches 1A, 2 and 3 met this requirement without mercury removal, but SB6 is estimated to contain approximately $1.5 \mathrm{wt} \%$ mercury in the incoming blended feed solids. The mercury concentration in the six hour sample and in the SRAT product sample (12-hour of boiling) is summarized in Table $\mathbf{1 5}$ and Table $\mathbf{1 6 .}$

Table 16 SRAT Product Mercury Results from Tests with SB6-A Baseline Sludge Simulant

\begin{tabular}{|c|c|c|}
\hline Acid Stoichiometry & $\begin{array}{c}\text { SRAT 6-hour Mercury, } \\
\text { Wt \% Total Solids Basis }\end{array}$ & $\begin{array}{c}\text { SRAT Product Mercury, } \\
\text { Wt \% Total Solids Basis }\end{array}$ \\
\hline 90\% (SB6-2) & 0.971 & 0.855 \\
\hline $100 \%($ SB6-1) & 0.729 & 0.525 \\
\hline $120 \%$ (SB6-3) & 1.387 & 0.094 \\
\hline $150 \%$ (SB6-4) & 0.136 & 0.064 \\
\hline
\end{tabular}

Table 17 SRAT Product Mercury Results from Tests with SB6-B Sludge Simulant (One Less Wash)

\begin{tabular}{|c|c|c|}
\hline Acid Stoichiometry & $\begin{array}{c}\text { SRAT 6-hour Mercury, } \\
\text { Wt \% Total Solids Basis }\end{array}$ & $\begin{array}{c}\text { SRAT Product Mercury, } \\
\text { Wt \% Total Solids Basis }\end{array}$ \\
\hline $100 \%$ & 0.734 & 0.714 \\
\hline $120 \%$ & 0.347 & 0.518 \\
\hline
\end{tabular}

The four runs with the lowest acid additions exceeded the DWPF mercury limit, although the $120 \%$ run with SB6B had a process sample that met the limit. Since it is not known which result is more valid, it was assumed that the higher result from the process sample was representative. If DWPF has problems achieving the mercury limit, a higher acid stoichiometry or longer stripping time may improve mercury removal. However, higher acid stoichiometry may also lead to higher hydrogen generation. Note also that the simulant testing was completed without a heel. 


\subsubsection{SRAT Cycle Offgas Composition Results}

A typical offgas concentration profile is shown in Figure 3, while charts from all runs are shown in Appendix A. Helium and nitrogen show reduced concentrations during periods with large quantities of offgas generation due to dilution, while oxygen showed reduced concentrations during these periods due to dilution and from consumption. In general, hydrogen generation began after nitrous oxide emissions had ceased and carbon dioxide emission was noted in conjunction with the hydrogen. The patterns of offgas emissions noted during the runs were typical of offgas generation during the SRAT cycle.

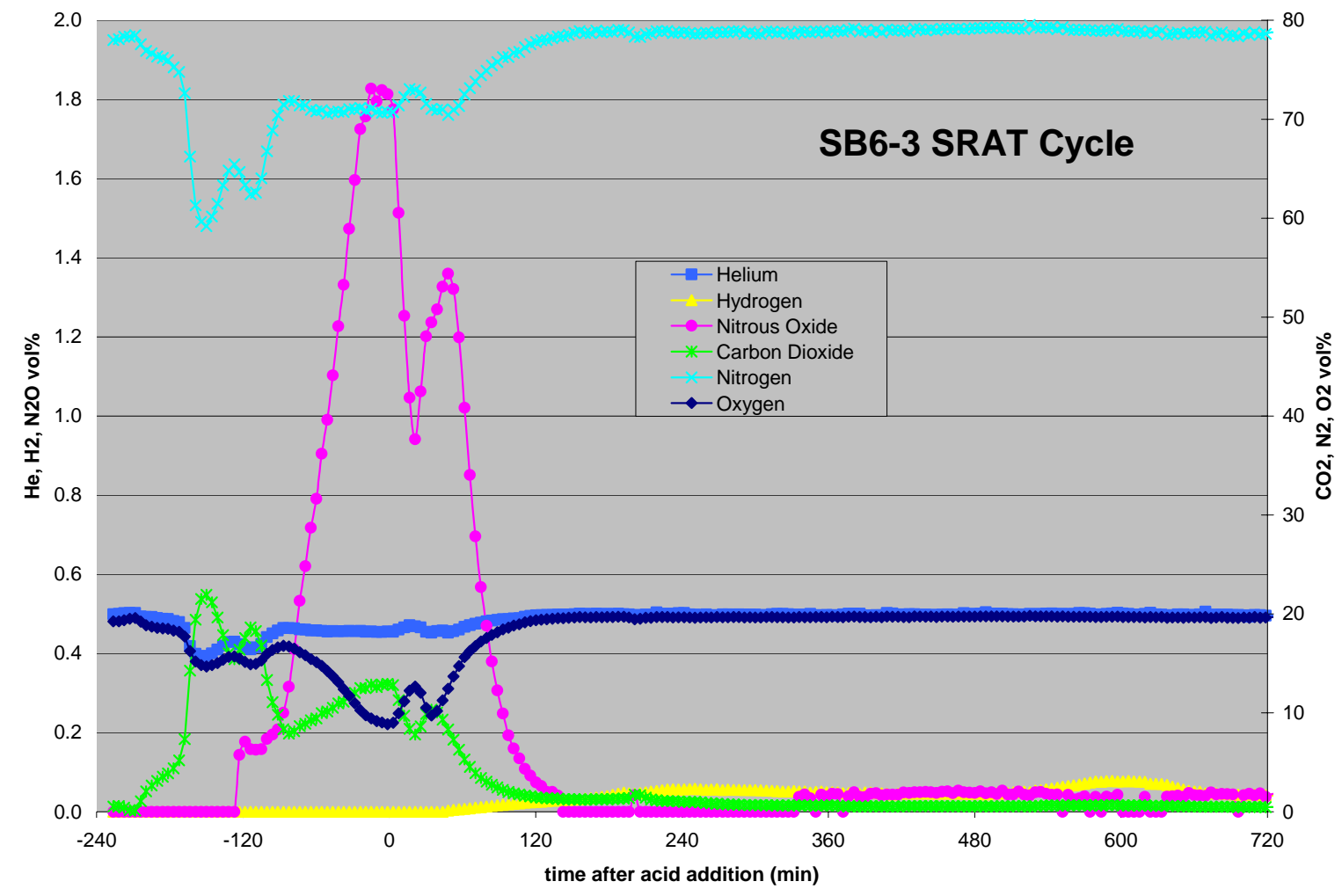

Figure 3. Typical SRAT Offgas Profile 120\% Acid Stoichiometry, SB6-A Baseline Sludge Simulant

\subsubsection{SRAT Hydrogen Evolution}

The peak hydrogen concentration for each SRAT run is shown in Figure 4. In general, the peak hydrogen generation rate increased with increased acid addition. None of the rates exceeded the DWPF SRAT processing limits of $0.65 \mathrm{lb} / \mathrm{hr}$, as shown in Table 18, which shows the peak hydrogen generation after scaling to the DWPF process. 


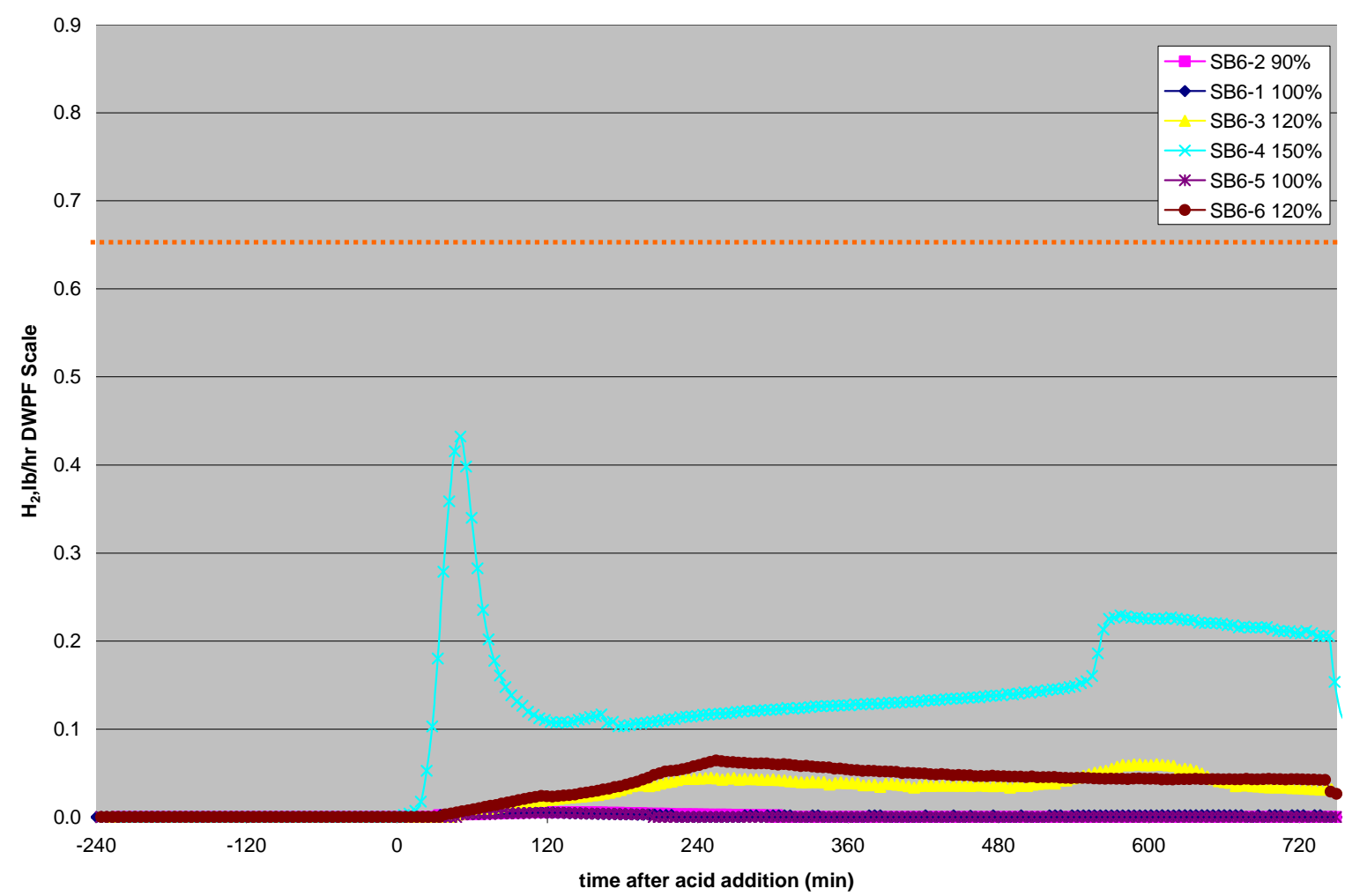

Figure 4. SRAT Cycle Hydrogen Peaks

Table 18 SRAT Cycle Hydrogen Peak Generation Rate

\begin{tabular}{|l|l|c|c|c|c|}
\hline \multicolumn{2}{|c|}{} & \multicolumn{4}{|c|}{ Acid Stoichiometry } \\
\hline $\begin{array}{c}\text { SRAT Hydrogen } \\
\text { Peak }\end{array}$ & Units & $\mathbf{9 0 \%}$ & $\mathbf{1 0 0 \%}$ & $\mathbf{1 2 0 \%}$ & $\mathbf{1 5 0 \%}$ \\
\hline SB6-A Simulant & $\mathrm{lb} / \mathrm{hr}$ & 0.006 & 0.006 & 0.060 & 0.432 \\
\hline SB6-B Simulant & $\mathrm{lb} / \mathrm{hr}$ & & 0.0050 & 0.064 & \\
\hline
\end{tabular}

\subsubsection{Other Species}

The nitrous oxide peak concentrations slightly increased as acid addition was increased, while the carbon dioxide peak was very similar for all runs. The peak generation of these species is less dependent on acid concentration than hydrogen since more acid is added than needed to destroy carbonate and nitrite, the compounds that are responsible for the highest emissions. The peak generation rates are shown in Table 19and Table 20after scaling to the DWPF process scale. 
Table 19 SRAT Cycle Nitrous Oxide and Carbon Dioxide Peak Generation Rates from Tests with SB6-A Baseline Sludge Simulant

\begin{tabular}{|l|l|c|c|c|c|}
\hline \multicolumn{2}{|l|}{} & \multicolumn{5}{|c|}{ Acid Stoichiometry } \\
\hline \multicolumn{2}{|l|}{} & $\mathbf{9 0 \%}$ & $\mathbf{1 2 0 \%}$ & $\mathbf{1 2 0 \%}$ & $\mathbf{1 5 0 \%}$ \\
\hline SRAT Nitrous Oxide Peak & $\mathrm{lb} / \mathrm{hr}$ & 20.9 & 29.1 & 33.8 & 35.8 \\
\hline SRAT Carbon Dioxide Peak & $\mathrm{lb} / \mathrm{hr}$ & 547 & 539 & 469 & 470 \\
\hline
\end{tabular}

Table 20 SRAT Cycle Nitrous Oxide and Carbon Dioxide Peak Generation Rates from Tests with SB6-B Sludge Simulant (One Less Wash)

\begin{tabular}{|l|c|c|c|}
\hline \multicolumn{2}{|c|}{} & \multicolumn{2}{c|}{ Acid Stoichiometry } \\
\cline { 3 - 4 } \multicolumn{2}{|c|}{} & $\mathbf{1 0 0 \%}$ & $\mathbf{1 2 0 \%}$ \\
\hline SRAT Nitrous Oxide Peak & $\mathrm{lb} / \mathrm{hr}$ & 22.1 & 31.5 \\
\hline SRAT Carbon Dioxide Peak & $\mathrm{lb} / \mathrm{hr}$ & 545 & 493 \\
\hline
\end{tabular}

\subsubsection{SRAT Product Rheological Properties}

The rheological properties of SRAT products were measured for the four runs produced with the simulant (SB6-A). The rheological properties were outside the processing limits for yield stress and consistency for SRAT products (yield stress 1.5 to $5 \mathrm{~Pa}$ and Consistency 5 to 12 $\mathrm{cP})^{+}$except for the 90 and $100 \%$ acid runs which were within the operation limits for yield stress and consistency. The yield stress and consistency of the SRAT products are shown in Table 21. It should be noted that differences between the rheological properties of the simulants and the actual waste have been noted during past qualification testing. Past simulants have typically had lower yield stress than actual waste.

Table 21 SRAT Product Rheological Properties with SB6-A Baseline Sludge Simulant

\begin{tabular}{|c|c|c|c|c|c|}
\hline Run & Acid \% & Yield Stress, Pa & $\begin{array}{c}\text { Consistency, } \\
\text { cP }\end{array}$ & $\begin{array}{c}\text { Insoluble Solids, wt } \\
\text { \% }\end{array}$ & $\begin{array}{c}\text { Total Solids, wt } \\
\text { \% }\end{array}$ \\
\hline SB6-2 & 90 & 2.73 & 9.40 & 15.7 & 26.3 \\
\hline SB6-1 & 100 & 3.24 & 8.22 & 14.7 & 26.1 \\
\hline SB6-3 & 120 & 0.36 & 4.47 & 12.9 & 25.3 \\
\hline SB6-4 & 150 & 0.05 & 3.44 & 14.6 & 25.8 \\
\hline
\end{tabular}

\subsection{SME CYCLE RESULTS}

The four SME cycles were performed immediately following the SRAT cycle and utilized the estimated amount of frit based on the initial sludge additions and the expected amount of SRAT samples. The SME cycles for Runs SB6-1, 2, 3 and 4 did not include the addition of water simulating decon water additions but all included two frit slurry additions. As stated earlier, the SME cycle targeted a final solids concentration of $45 \mathrm{wt} \%$ total solids based on

\footnotetext{
$\$$ “Technical Data Summary for the Defense Waste Processing Facility: Sludge Plant”, DPSTD-80-38-2
} 
earlier testing with SB4 and 5 that resulted in extremely viscous slurries at the end of the SME cycle ${ }^{15}$.

\subsubsection{Processing Observations}

Only hydrogen generation was noted as a potential processing issue during the SME cycle. The hydrogen generation in the highest acid run exceeded the DWPF hydrogen limit at during the final dewater at the completion of the SME cycle. Mixing was not an issue during processing. Mixer speed was maintained at 250 RPM throughout each run.

As shown in Figure 5, the $\mathrm{pH}$ profile of each SME cycle followed a similar profile with a dip in $\mathrm{pH}$ as the frit is added due to the formic acid content of the frit slurry followed by a gradual rise in $\mathrm{pH}$ as the slurry mix is evaporated.

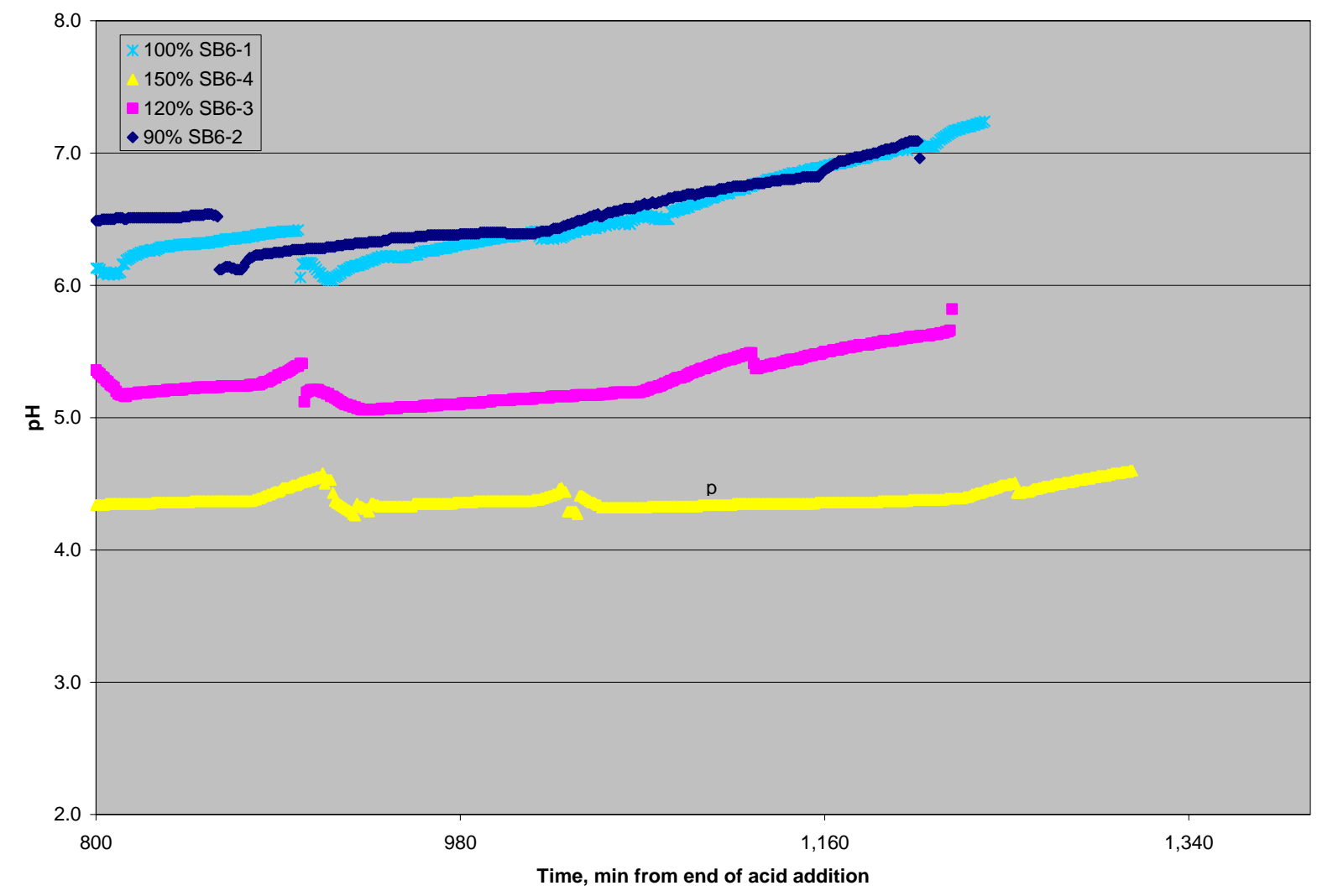

Figure 5. SME pH Profile from Tests with SB6-A Baseline Sludge Simulant

\subsubsection{SME Cycle Sample Results}

Samples were pulled at the conclusion of the SME cycle and analyzed for total solids, anions, soluble elemental species, TOC, and mercury. Samples were taken of the composite SME dewater and the FAVC contents at the completion of the SME cycle.

The solids contents of the SME products are shown in Table 22 along with the calculated waste loading and $\mathrm{pH}$. The solids contents generally were higher than targeted, but the waste loading targets were lower than the $38 \%$ target. Waste loadings were calculated from the PSAL analyzed lithium content of the SME product (the frit 418 was $7.42 \% \mathrm{Li}$ ). 
Table 22 SME Product Results from Tests with SB6-A Baseline Sludge Simulant

\begin{tabular}{|c|c|c|c|c|}
\hline Acid \% & pH & $\begin{array}{c}\text { Total Solids } \\
\text { wt\% }\end{array}$ & $\begin{array}{c}\text { Lithium Oxide } \\
\text { Content (wt \% } \\
\text { Calcined } \\
\text { solids) }\end{array}$ & $\begin{array}{c}\text { Waste } \\
\text { Loading§ } \\
\text { Wt \% }\end{array}$ \\
\hline SB6-2 90\% & 7.38 & 47.15 & 4.71 & $36.5 \%$ \\
\hline SB6-1 100\% & 7.67 & 46.8 & 4.74 & $36.1 \%$ \\
\hline SB6-3 120\% & 5.85 & 46.9 & 4.82 & $35.0 \%$ \\
\hline SB6-4 150\% & 4.97 & 47.4 & 4.94 & $33.5 \%$ \\
\hline
\end{tabular}

Loss of formate varied during the SME cycles, as shown in Table 23. The range of values noted during the testing is similar to results from previous runs.

Table 23 SME Product Anion Conversions from Tests with SB6-A Baseline Sludge Simulant

\begin{tabular}{|l|c|c|}
\hline \multirow{2}{*}{$\begin{array}{l}\text { ACID } \\
\text { STOICHIOMETRY }\end{array}$} & \multicolumn{2}{|c|}{ SME Cycle } \\
\cline { 2 - 3 } & $\begin{array}{c}\text { Formate } \\
\text { Destruction }\end{array}$ & $\begin{array}{c}\text { Nitrate } \\
\text { Destruction }\end{array}$ \\
\hline SB6-2 90\% & $6.1 \%$ & $3.4 \%$ \\
\hline SB6-1 100\% & $6.0 \%$ & $4.1 \%$ \\
\hline SB6-3 120\% & $2.8 \%$ & $4.3 \%$ \\
\hline SB6-4 150\% & $10.3 \%$ & $6.8 \%$ \\
\hline
\end{tabular}

Total Organic Carbon (TOC) results are shown in Appendix B, but appear to be biased high based on the formate results. The TOC values listed exceed the TOC limits for the current sludge batch, but the values obtained based on the formate results meet TOC limits. The formate analysis is typically more accurate than the TOC analysis.

\subsubsection{SME Cycle Offgas Composition Results}

The amount of offgas generated during the runs generally increased as acid stoichiometry increased, as indicated by the helium concentration in the offgas since helium is added at a constant $0.5 \mathrm{wt} \%$ of the incoming air purge. A typical offgas concentration profile is shown in Figure 6. The patterns of offgas emissions noted during the runs were typical of offgas generation during the SME cycle with hydrogen and carbon dioxide emissions occurring during dewatering after each frit addition. The dip in concentrations near the run time of 900 minutes is the result of cooling the vessel and adding the second frit addition.

\footnotetext{
$\S \%$ Waste Loading $=(1-$ Lithium in SME product $/ 7.42) * 100 \%$
} 
SRNL-STI-2009-00413, REVISION 0

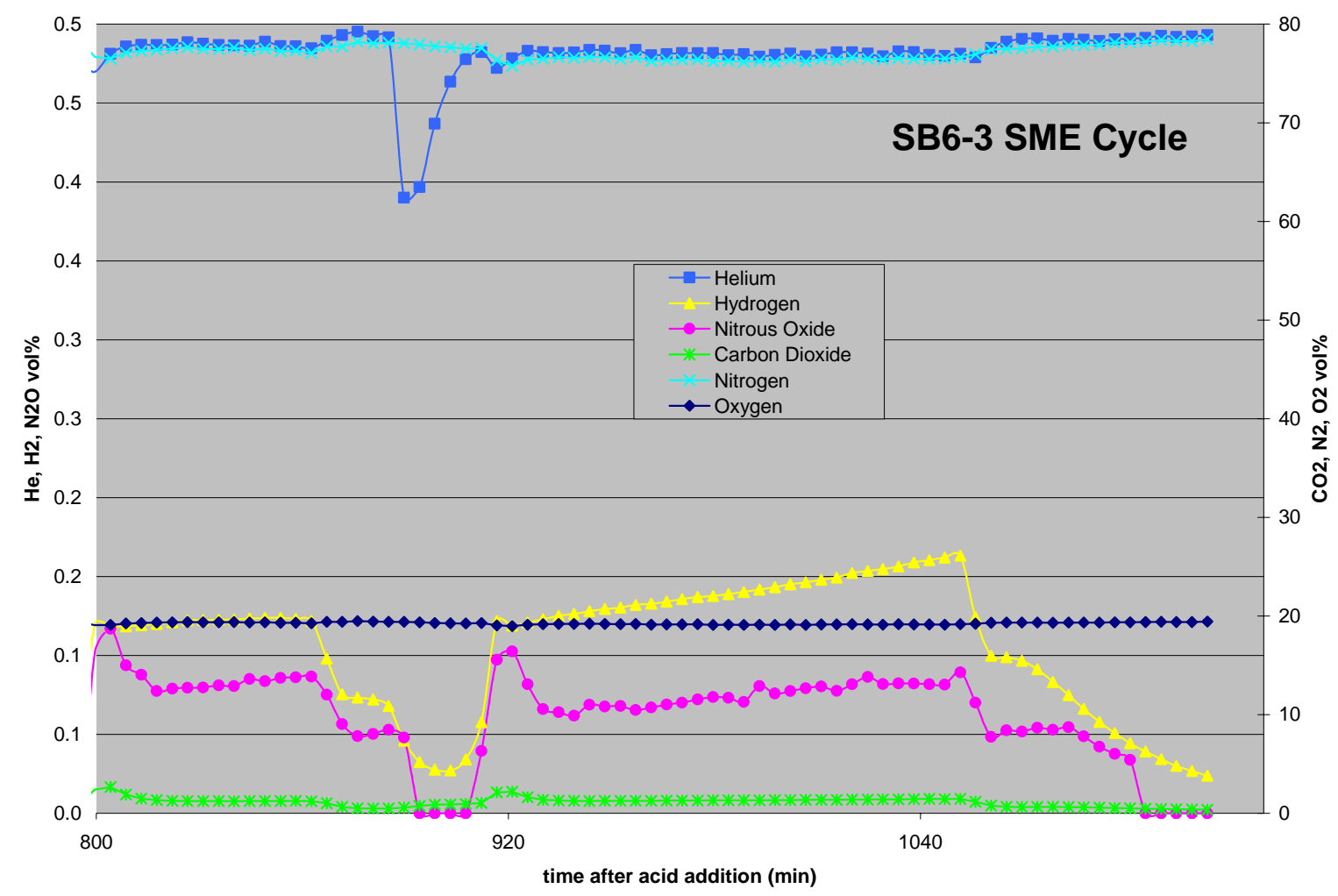

Figure 6. Typical SME Offgas Profile 120\% Acid Stoichiometry, SB6-A Baseline Sludge Simulant

\subsubsection{Hydrogen Evolution}

The peak hydrogen generation rates were generally noted as sharp spikes in the data immediately following the start of dewater, as shown in Figure 6 above. Hydrogen reached concentrations higher than noted in the SRAT cycle due to the decreased purge during the SME cycle. Peak hydrogen concentrations reached close to 0.5 volume $\%$, as shown in Figure 7 and Figure 8, and were a function of acid stoichiometry. Peak generation rates scaled to the DWPF process are shown in Table $\mathbf{2 4}$ and were all below the SME process limit of $0.223 \mathrm{lb} / \mathrm{hr}$, except for the $150 \%$ stoichiometry. 


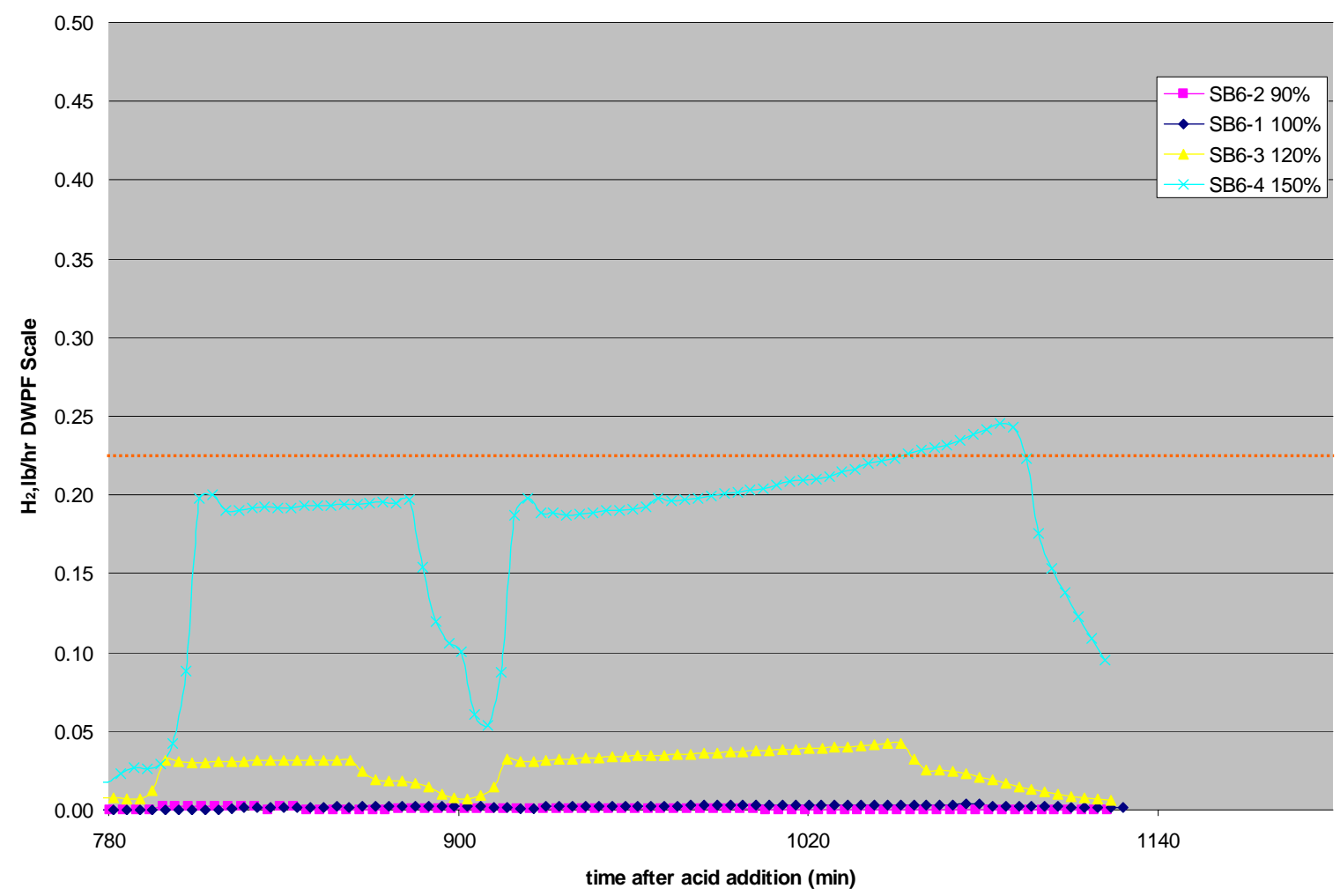

Figure 7. SME Hydrogen Generation

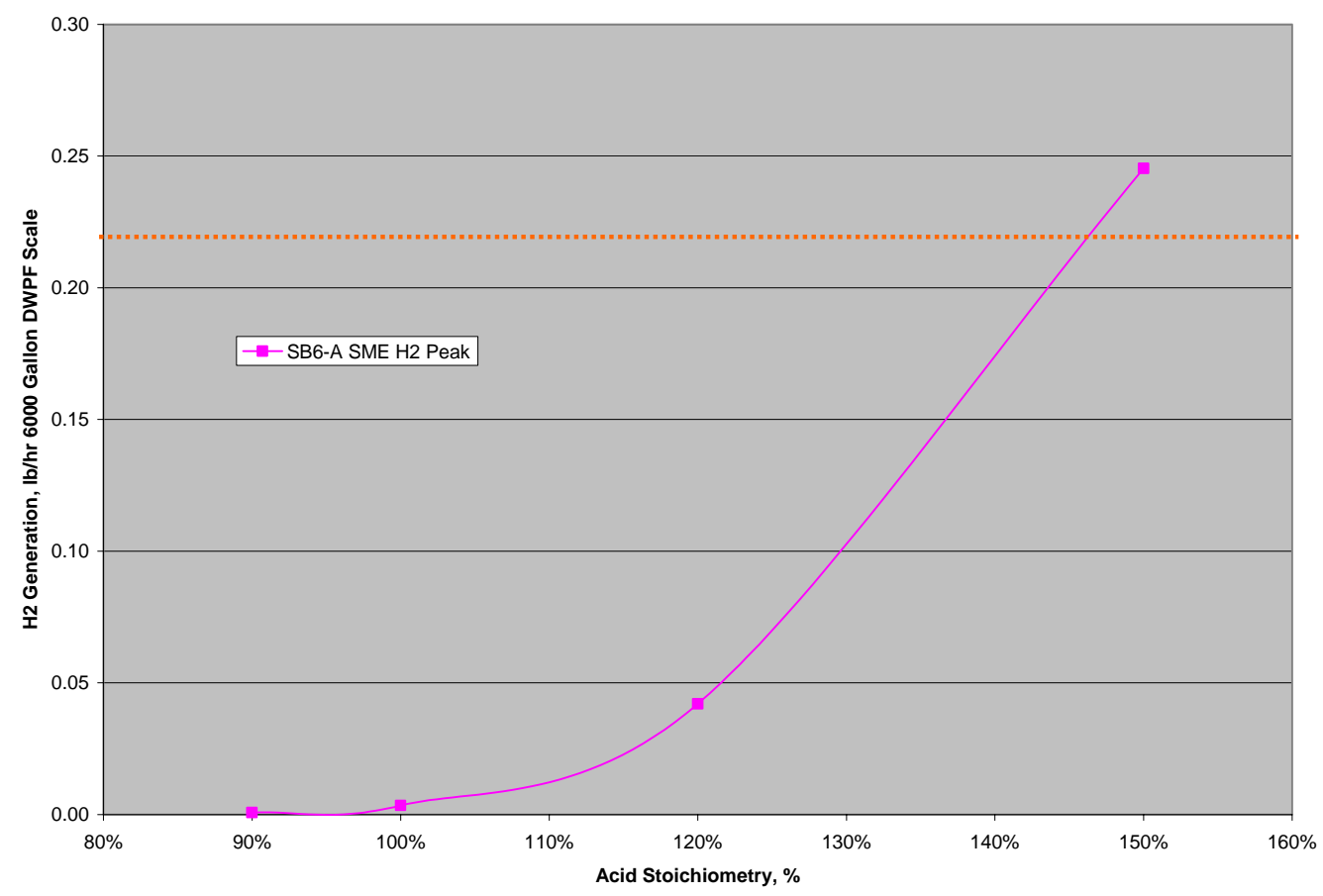

Figure 8. Peak Hydrogen Generation during SME Cycle, SB6-A Baseline Sludge Simulant 
Table 24 SME Cycle Hydrogen Peak Generation Rate, SB6-A Baseline Sludge Simulant

\begin{tabular}{|l|l|c|c|c|c|}
\hline \multicolumn{2}{|l|}{ SME Hydrogen Peak } & \multicolumn{4}{|c|}{ Acid Stoichiometry } \\
\cline { 3 - 6 } \multicolumn{2}{l|}{} & $\mathbf{9 0 \%}$ & $\mathbf{1 0 0 \%}$ & $\mathbf{1 2 0} \%$ & $\mathbf{1 5 0 \%}$ \\
\hline SB6-A Simulant & $\mathrm{lb} / \mathrm{hr}$ & 0.001 & 0.004 & 0.042 & 0.245 \\
\hline
\end{tabular}

\subsubsection{Other Species}

Carbon dioxide, as shown in Table 25, was generally the only other gas of any significance emitted during the SME cycle (the lower acid runs contained a small amount of nitrous oxide emissions from the nitrite remaining after the SRAT cycle).

Table 25 SME Cycle Nitrous Oxide and Carbon Dioxide Peak Generation Rates from Tests with SB6-A Baseline Sludge Simulant

\begin{tabular}{|l|l|c|c|c|c|}
\hline \multicolumn{2}{|l|}{} & \multicolumn{5}{|c|}{ Acid Stoichiometry } \\
\hline \multicolumn{2}{|l|}{} & $\mathbf{9 0 \%}$ & $\mathbf{1 0 0 \%}$ & $\mathbf{1 2 0 \%}$ & $\mathbf{1 5 0 \%}$ \\
\hline SRAT Nitrous Oxide Peak & $\mathrm{lb} / \mathrm{hr}$ & 0.95 & 0.44 & 0.66 & 0.00 \\
\hline SRAT Carbon Dioxide Peak & $\mathrm{lb} / \mathrm{hr}$ & 19.1 & 21.3 & 14.9 & 17.9 \\
\hline
\end{tabular}

\subsubsection{SME Product Rheological Properties}

The rheological properties of each SME product were measured. Higher acid stoichiometry lowered the yield stress and consistency of the SME products. All runs were within the process limits for yield stress $(2.5$ to $15 \mathrm{~Pa})$ and consistency $(10$ to $40 \mathrm{cP}){ }^{* *}$ as shown in Table 26.

Table 26 SME Product Rheological Properties from Tests with SB6-A Baseline Sludge Simulant

\begin{tabular}{|c|c|c|c|c|}
\hline Run & Acid \% & Yield Stress, Pa & Consistency, cP & Total Solids, wt \% \\
\hline SB6-2 & $90 \%$ & 8.56 & 32.34 & 46.8 \\
\hline SB6-1 & $100 \%$ & 4.95 & 25.56 & 47.1 \\
\hline SB6-3 & $120 \%$ & 3.58 & 30.04 & 46.4 \\
\hline SB6-4 & $150 \%$ & 4.50 & 16.75 & 47.4 \\
\hline
\end{tabular}

\subsubsection{Other Notable Observations}

Two notable observations by the technicians were unusual and are noted below.

1. The agitator blades and shaft from SB6-4 had black deposits covering all surfaces (Figure 9). For comparison, the agitator from run SB6-1, the lowest acid run, was virtually without deposits of solids on the surfaces. The film was resistant to rinsing, was not removed by soaking in nitric acid and required mechanical cleaning to remove. The material deposited on the shaft contained mercury and likely contained noble metals, but speciation was not performed.

\footnotetext{
** “Technical Data Summary for the Defense Waste Processing Facility: Sludge Plant”, DPSTD-80-38-2
} 


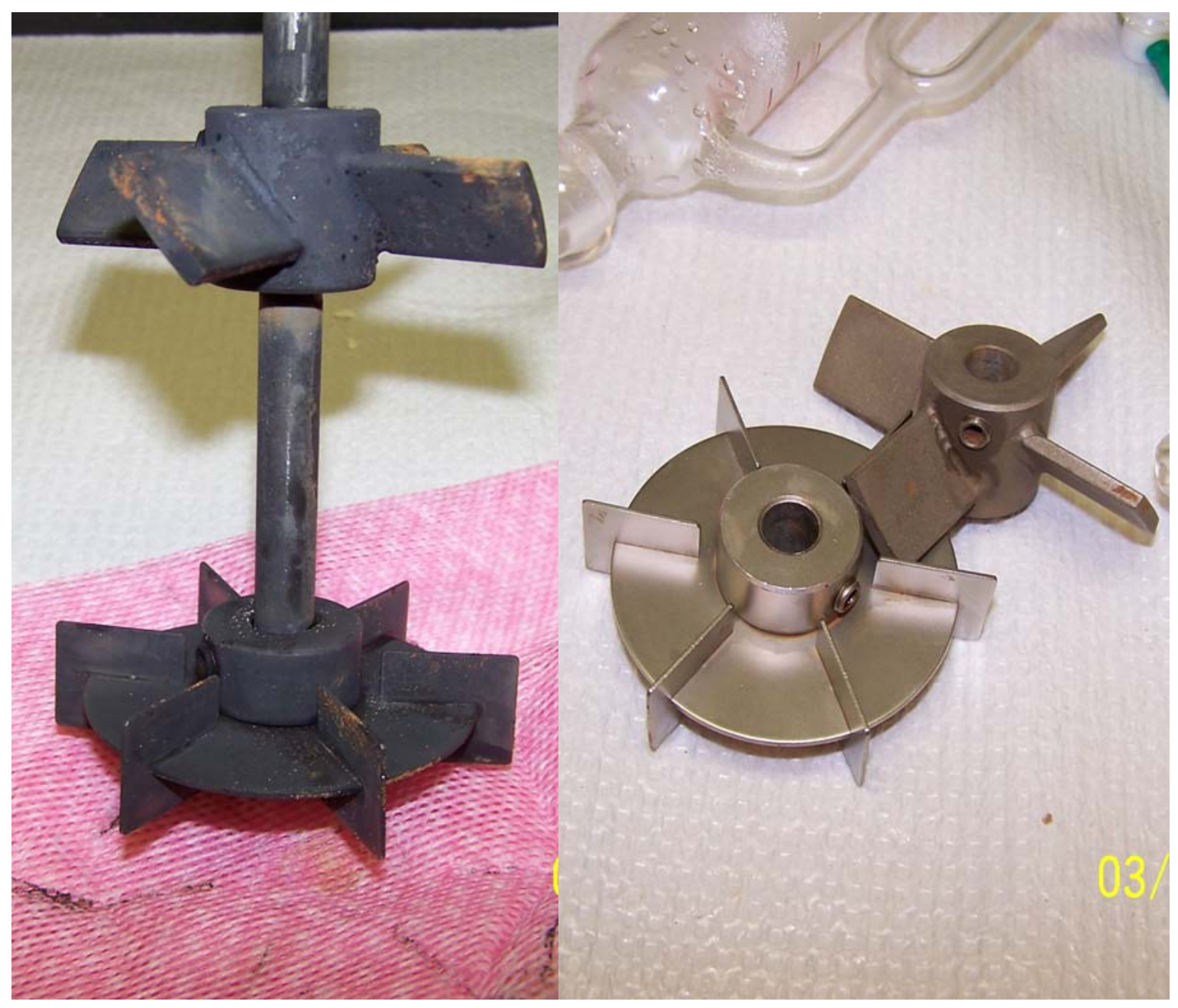

Figure 9. Photos of SB6-4 Agitator Blades and Shaft (left) and SB6-1 Agitator Blades (right)

2. The SME products were saved for melt rate testing. Before combining the four SME products, the technicians noted dark solids in the three lowest acid runs. 


\subsection{CONCLUSIONS}

Six DWPF process simulations were completed in 4-L laboratory-scale equipment using two projections of the SB6 blend simulant composition (Tank 40 composition after Tank 51 transfer on a 40" Tank 40 heel is complete). The more washed simulant (SB6-A washed to nominally $1 \mathrm{M} \mathrm{Na}$ ) had a set of four SRAT and SME simulations at varying acid stoichiometry levels $(90 \%, 100 \%, 120 \%$ and 150\%). Two additional SRAT simulations were made using SB6-B blend simulant (nominally $1.2 \mathrm{M} \mathrm{Na}$ ) at $100 \%$ and $120 \%$ of acid stoichiometry. Acid predictions used the Koopman Acid Prediction Calculation. ${ }^{16}$

Two SB6 processing issues were noted during initial flowsheet testing. First, a high hydrogen generation rate was measured during the SB6-A experiment with the highest acid stoichiometry. Second, in the lower acid runs for both SB6-A and SB6-B sludge, the mercury concentration exceeded the $0.45 \mathrm{wt} \% \mathrm{Hg}$ in SRAT product solids limit.

Three items were specifically requested in the TTR and are discussed below.

\section{Hydrogen and nitrous oxide generation rates as a function of acid stoichiometry}

Hydrogen generation was significantly impacted by the changes in acid stoichiometry from $90 \%$ to $150 \%$ (1.45 to 2.42 moles acid per liter of SB6-A sludge or 1.83 to 2.20 moles acid per liter of SB6-B sludge). For the SB6-A sludge, the hydrogen generation rate was within DWPF limits in the SRAT cycle, but exceeded the process limit during the SME cycle at the highest acid stoichiometry (150\%). Both of the SB6-B experiments were within the process limits throughout the SRAT even though the stoichiometric acid requirement was higher. No SME cycles were performed with the SB6-B feed. The nitrous oxide generation peak was relatively insensitive to acid stoichiometry and was relatively low due to the low starting nitrite concentration. Hydrogen generation and nitrous oxide generation scaled to DWPF are shown in Table 27 and Table 28.

Table 27. Offgas Peak Summary - SB6-A Baseline Sludge Simulant

\begin{tabular}{|l|c|c|c|c|c|}
\hline \multicolumn{2}{|c|}{} & \multicolumn{5}{c|}{ Acid Stoichiometry } \\
\cline { 3 - 6 } \multicolumn{2}{|c|}{} & $\mathbf{9 0 \%}$ & $\mathbf{1 0 0 \%}$ & $\mathbf{1 2 0 \%}$ & $\mathbf{1 5 0 \%}$ \\
\hline SRAT Hydrogen Peak & $\mathrm{lb} / \mathrm{hr}$ & 0.0056 & 0.0058 & 0.0602 & 0.4322 \\
\hline SME Hydrogen Peak & $\mathrm{lb} / \mathrm{hr}$ & 0.001 & 0.004 & 0.042 & 0.245 \\
\hline SRAT Nitrous Oxide Peak & $\mathrm{lb} / \mathrm{hr}$ & 20.9 & 29.1 & 33.8 & 35.8 \\
\hline SME Nitrous Oxide Peak & $\mathrm{lb} / \mathrm{hr}$ & 0.95 & 0.44 & 0.66 & 0.00 \\
\hline $\begin{array}{l}\text { SRAT Carbon Dioxide } \\
\text { Peak }\end{array}$ & $\mathrm{lb} / \mathrm{hr}$ & 547 & 539 & 469 & 470 \\
\hline SME Carbon Dioxide Peak & $\mathrm{lb} / \mathrm{hr}$ & 19.1 & 21.3 & 14.9 & 17.9 \\
\hline
\end{tabular}


Table 28. Offgas Peak Summary - SB6-B Sludge Simulant (One Less Wash)

\begin{tabular}{|l|c|c|c|}
\hline \multirow{2}{*}{\multicolumn{2}{|c|}{}} & \multicolumn{2}{c|}{$\begin{array}{c}\text { Acid } \\
\text { Stoichiometry }\end{array}$} \\
\cline { 3 - 4 } & $\mathbf{1 0 0 \%}$ & $\mathbf{1 2 0 \%}$ \\
\hline SRAT Hydrogen Peak & $\mathrm{lb} / \mathrm{hr}$ & 0.0050 & 0.0642 \\
\hline $\begin{array}{l}\text { SRAT Nitrous Oxide Peak } \\
\text { SRAT Carbon Dioxide } \\
\text { Peak }\end{array}$ & $\mathrm{lb} / \mathrm{hr}$ & 22.1 & 31.5 \\
\hline
\end{tabular}

\section{Acid quantities and processing times required for mercury removal}

Mercury was added to the sludge simulant at the start of the SRAT cycle as mercuric oxide at $1.5 \mathrm{wt} \%$ (total solids basis) based on the expected composition of the SB6 blend. In the higher acid runs, 12 hours of boiling was sufficient time to strip mercury below the $0.45 \mathrm{wt}$ $\%$ SRAT limit. Boiling flux was maintained at a scaled rate of $5,000 \mathrm{lb} / \mathrm{hr}$ so a total of $60,000 \mathrm{lb}$ of steam flow in DWPF would be needed to remove $120 \mathrm{lb}$ of mercury. Acid quantities from $120 \%$ to $150 \%$ resulted in satisfactory mercury removal with 12 hours of boiling time. The two lowest acid stoichiometry runs with the SB6-A simulant did not meet the process limit after 12 hours of boiling and neither run with the SB6-B simulant met the $0.45 \mathrm{wt} \%$ limit. A general trend of more efficient stripping was noted at higher acid stoichiometries. If DWPF experiences problems stripping mercury, increasing the boiling time or increasing the acid stoichiometry is likely to improve mercury removal but may also increase hydrogen generation. Longer boiling times will be used in future SB6 testing to ensure the mercury concentration is below the SRAT limit.

\section{Acid quantities and processing times required for nitrite destruction}

Acid quantities from $100 \%$ to $150 \%$ resulted in satisfactory nitrite destruction with 12 hours of boiling. In all runs, except the $90 \%$ run, the amount of nitrite present in the SRAT product was less than the $1,000 \mathrm{mg} / \mathrm{kg}$ target. The low starting nitrite concentration helped to reduce the nitrite by the end of the SRAT cycle. 


\subsection{REFERENCES}

1 Bricker, J.M., Sludge Batch 6 Flowsheet Studies, HIW-DWPF-TTR-2008-0043, Revision 0, Savannah River Site, Aiken, SC 29808 (2008).

2 Lambert, D.P., Sludge Batch 6 Simulant Flowsheet Studies, SRNL-RP-2008-01341, Rev. 0, Savannah River Site, Aiken, SC 29808 (2009).

3 H.B. Shah and D.D. Larsen, Sludge Batch 6 Projected Batch and Blend Compositions, LWOLWP-2009-00001, Savannah River Site, Aiken, SC 29808 (2009).

4 Jeff Gillam, SB6a Supernate Basis LWO Sheet.xls, January 20, 2009.

5 Koopman, D.C., A.I. Fernandez, B.R. Pickenheim, Preliminary Evaluations of Two Proposed Stoichiometric Acid Equations, Revision 0, Savannah River Site, Aiken, SC 29808 (2009).

6 Bricker, J.M., Sludge Batch 6 Flowsheet Studies, HIW-DWPF-TTR-2008-0043, Revision 0, Savannah River Site, Aiken, SC 29808 (2008).

7 J.D. Newell, SB6-A Simulant Development, SRNL-L3100-2009-00069, Savannah River Site, Aiken, SC 29808 (2009).

8 Manual L29, Procedure ITS-00124, Rev 2, SRS HLW Sludge Simulant Preparation Savannah River Site, Aiken, SC 29808 (2008).

9 Stone, M. E., Lab-Scale CPC Equipment Set-up, SRNL-ITS-2006-00074, Savannah River Site, Aiken, SC 29808 (2008).

10 Manual L29, Procedure ITS-0094, Rev. 3, Laboratory Scale Chemical Process Cell Simulations, Savannah River Site, Aiken, SC 29808 (2006).

11 SB6 Simulant CPC Flowsheet Studies, WSRC-NB-2009-00094.

12 Jantzen, C.M., J.R. Zamecnik, D.C. Koopman, C.C. Herman, and J.B. Pickett, Electron Equivalents Model for Controlling Reduction-Oxidation (Redox) Equilibrium during High Level Waste (HLW) Vitrification, WSRC-TR-2003-00126, Savannah River Site, Aiken, SC 29808 (2003).

13 Lambert, D. P., Acid Calculation Spreadsheet for DWPF Simulations, Revision 1 (Dated 8/14/06), SRNL-PSE-2006-00173, Savannah River Site, Aiken, SC 29808 (2006).

14 Lambert, D.P., M. E. Stone, B. R. Pickenheim, D. R. Best, D. C. Koopman, Sludge Batch 5 Simulant Flowsheet Studies, SRNS-STI-2008-00024, Revision 0, Savannah River Site, Aiken, SC 29808 (2008).

15 Stone, M. E., FY06 Feed Preparation for Melt Rate Testing, WSRC-STI-2006-0007, Savannah River Site, Aiken, SC 29808 (2006). 
16 Koopman, D.C., A.I. Fernandez, B.R. Pickenheim, Preliminary Evaluations of Two Proposed Stoichiometric Acid Equations, Revision 0, SRNL-L3100-2009-00146, Savannah River Site, Aiken, SC 29808 (2009). 
SRNL-STI-2009-00413, REVISION 0

$-35-$ 


\section{APPENDIX A. Offgas Data}

The following graphs were generated using offgas composition information using Agilent micro gas chromatographs. The data was reprocessed after each run by John Pareizs to recalculate the concentration of any missed peaks or other instrument anomalies.

The following graphs are included in this appendix:

Figure A1 SB6-1 Offgas Profile (SRAT and SME Cycle)

Figure A2 SB6-2 Offgas Profile (SRAT and SME Cycle)

Figure A3 SB6-3 Offgas Profile (SRAT and SME Cycle)

Figure A4 SB6-4 Offgas Profile (SRAT and SME Cycle)

Figure A5 SB6-5 Offgas Profile (SRAT Cycle Only)

Figure A6 SB6-6 Offgas Profile (SRAT Cycle Only) 
Figure A1-SB6-1 SRAT and SME Cycle GC Data

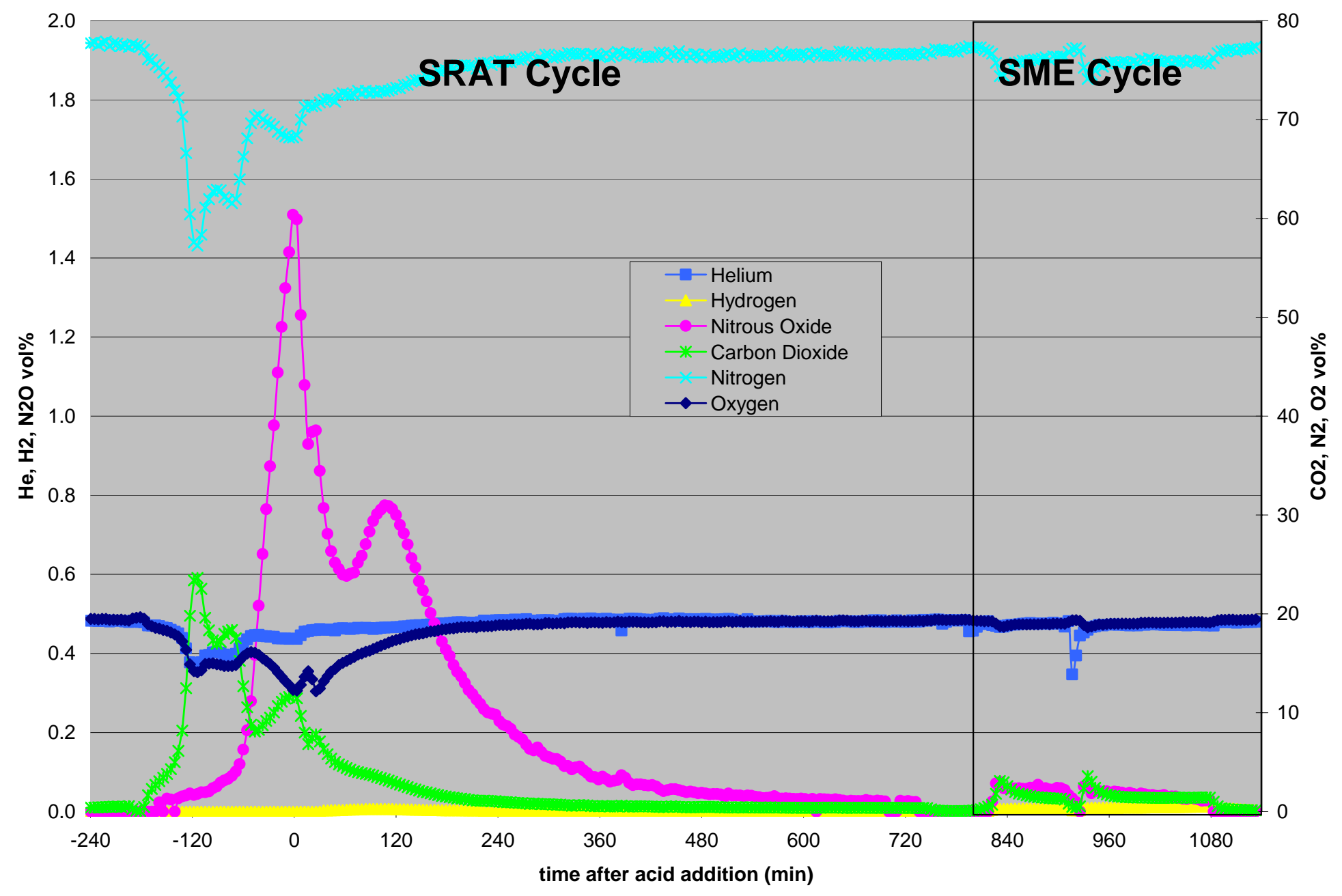


Figure A2-SB6-2 SRAT and SME Cycle GC Data

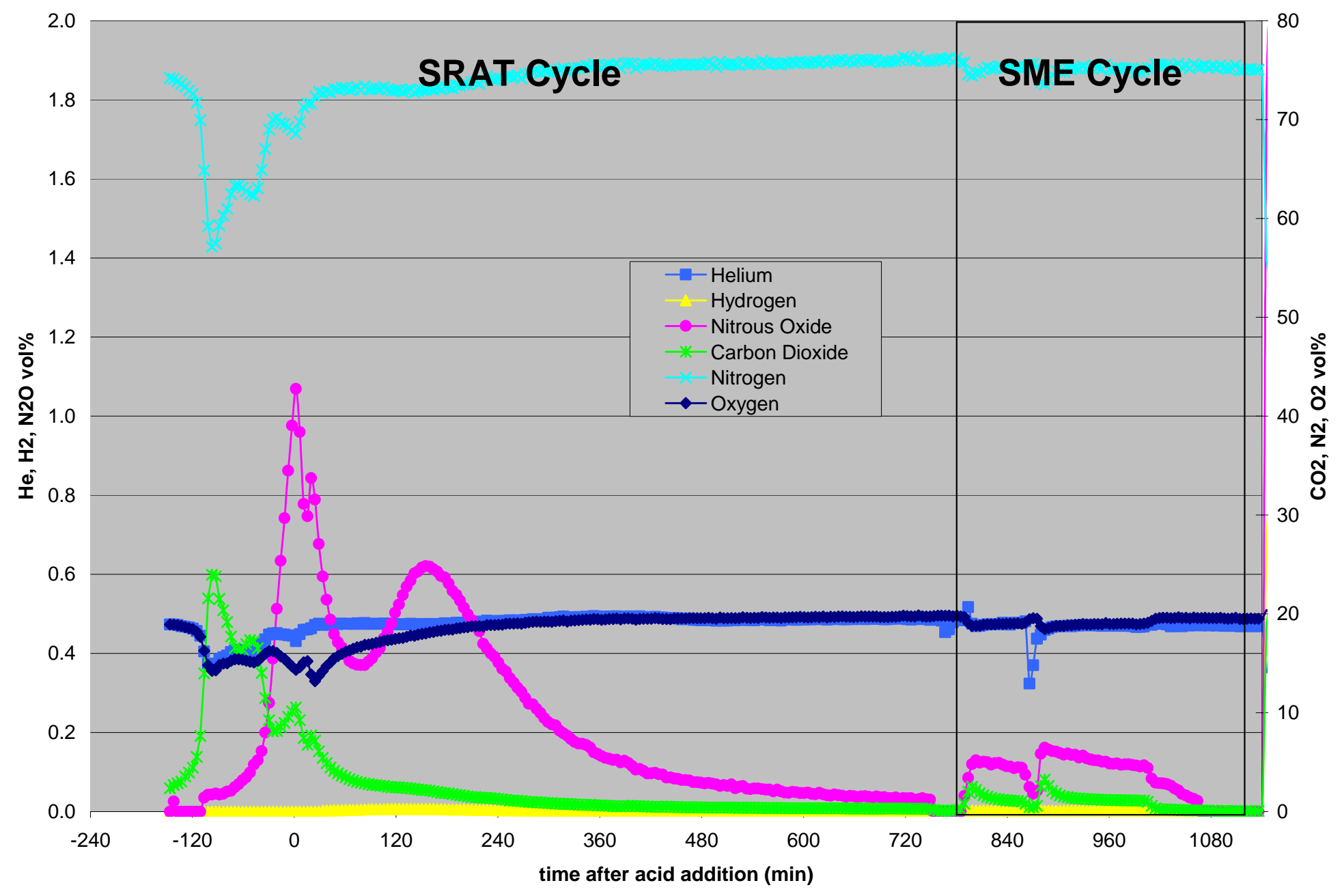


Figure A3-SB6-3 SRAT and SME Cycle GC Data

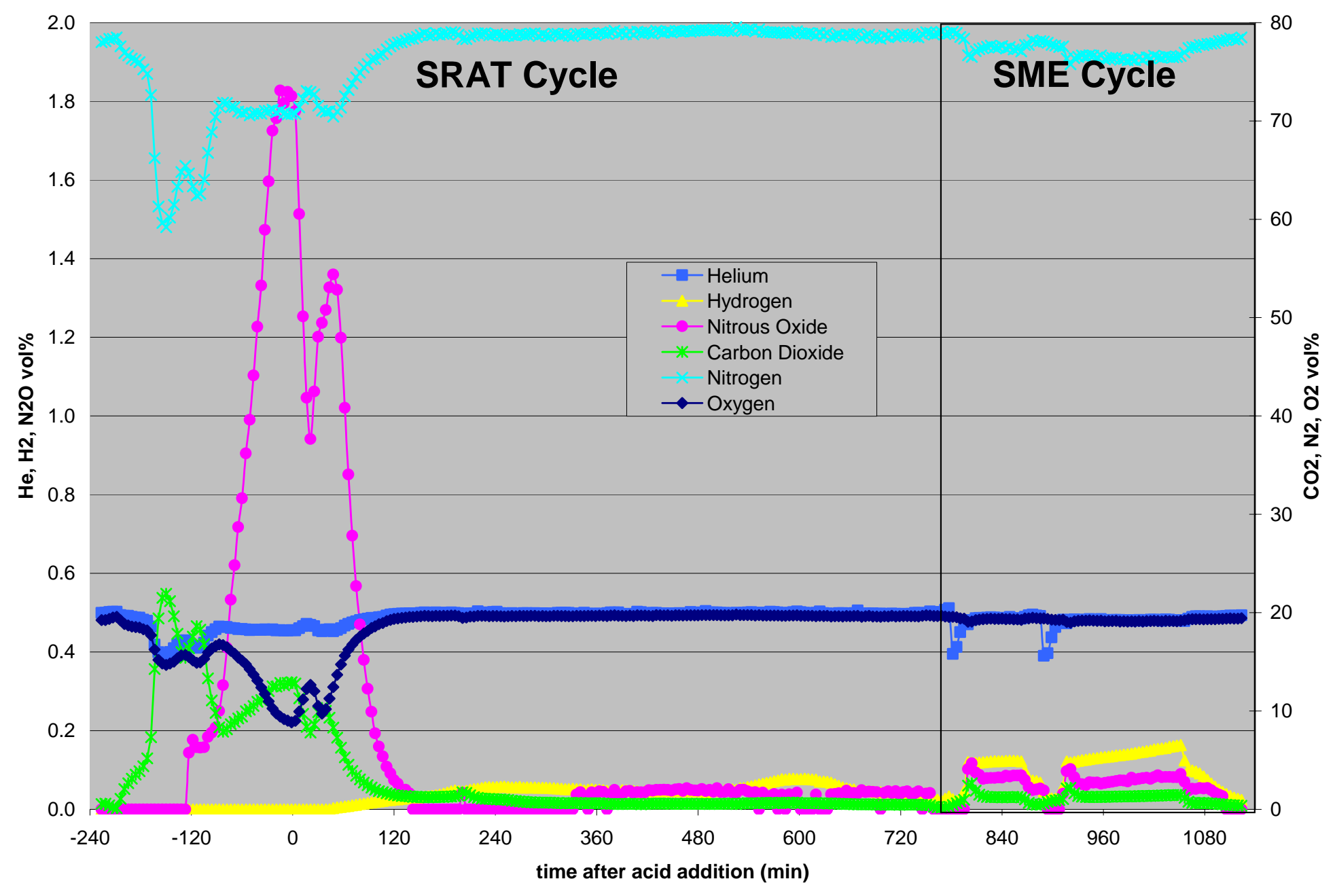


Figure A4-SB6-4 SRAT and SME Cycle GC Data

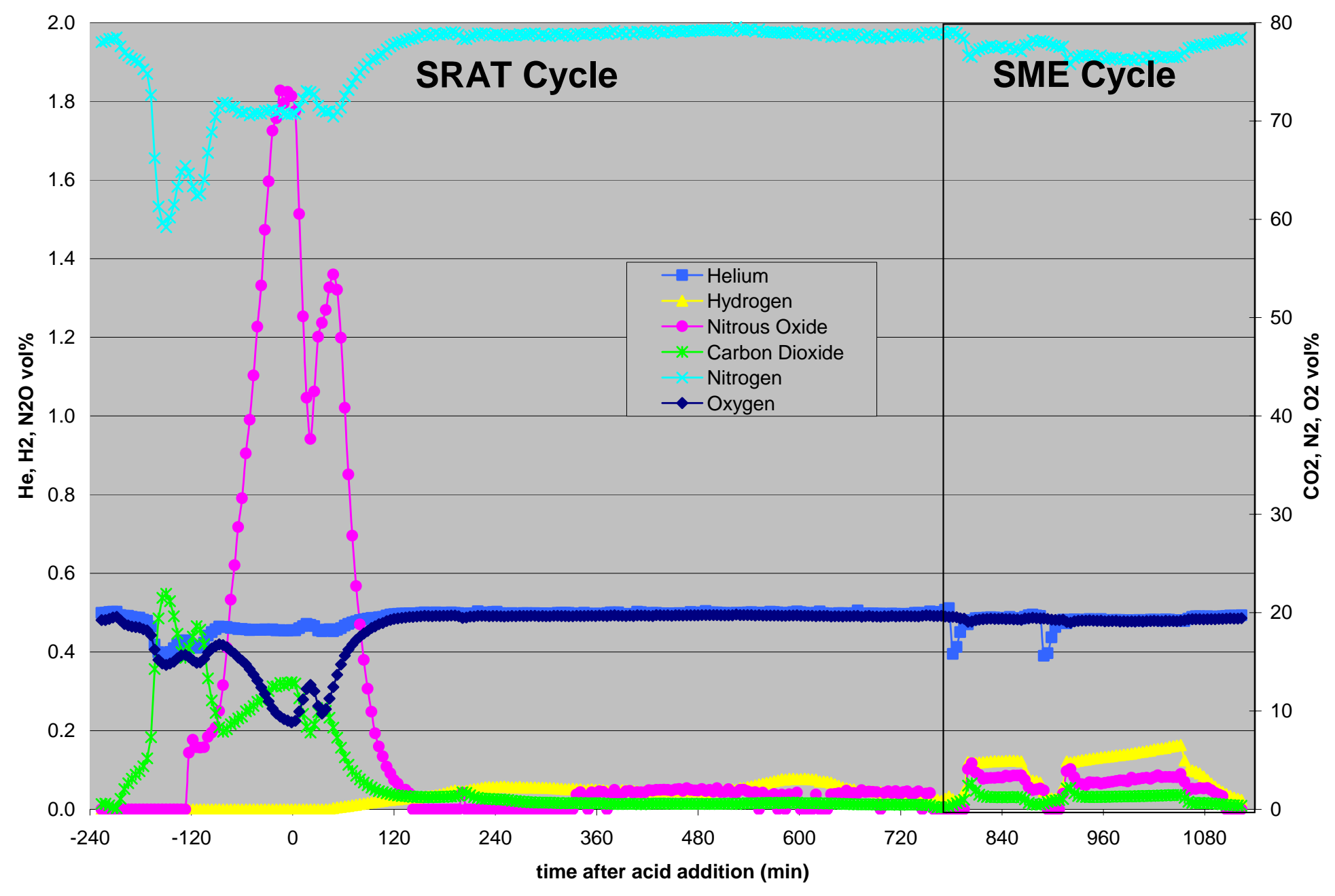


Figure A5-SB6-5 SRAT Cycle GC Data (No SME Cycle)

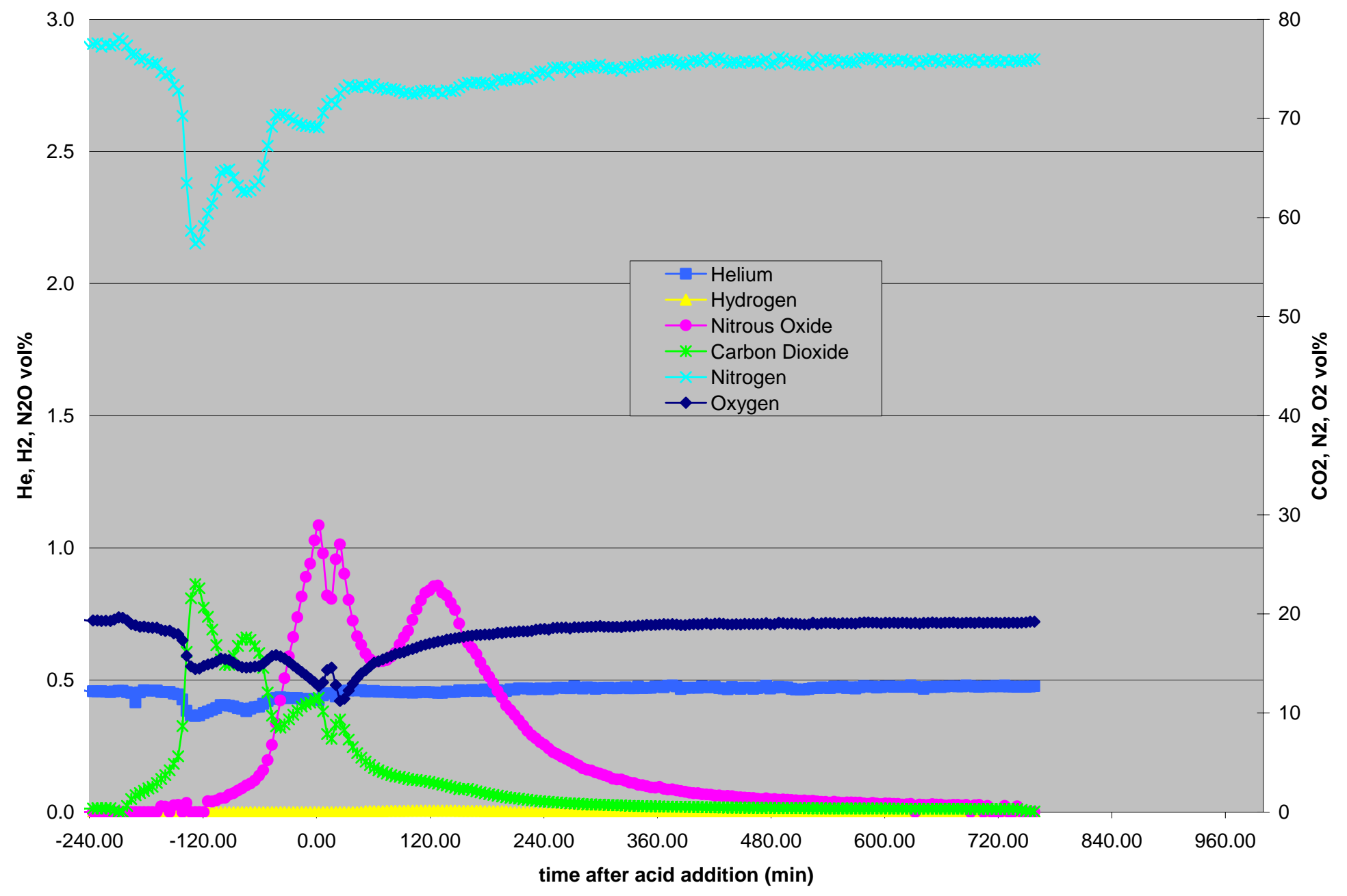


Figure A6-SB6-6 SRAT Cycle GC Data (No SME Cycle)

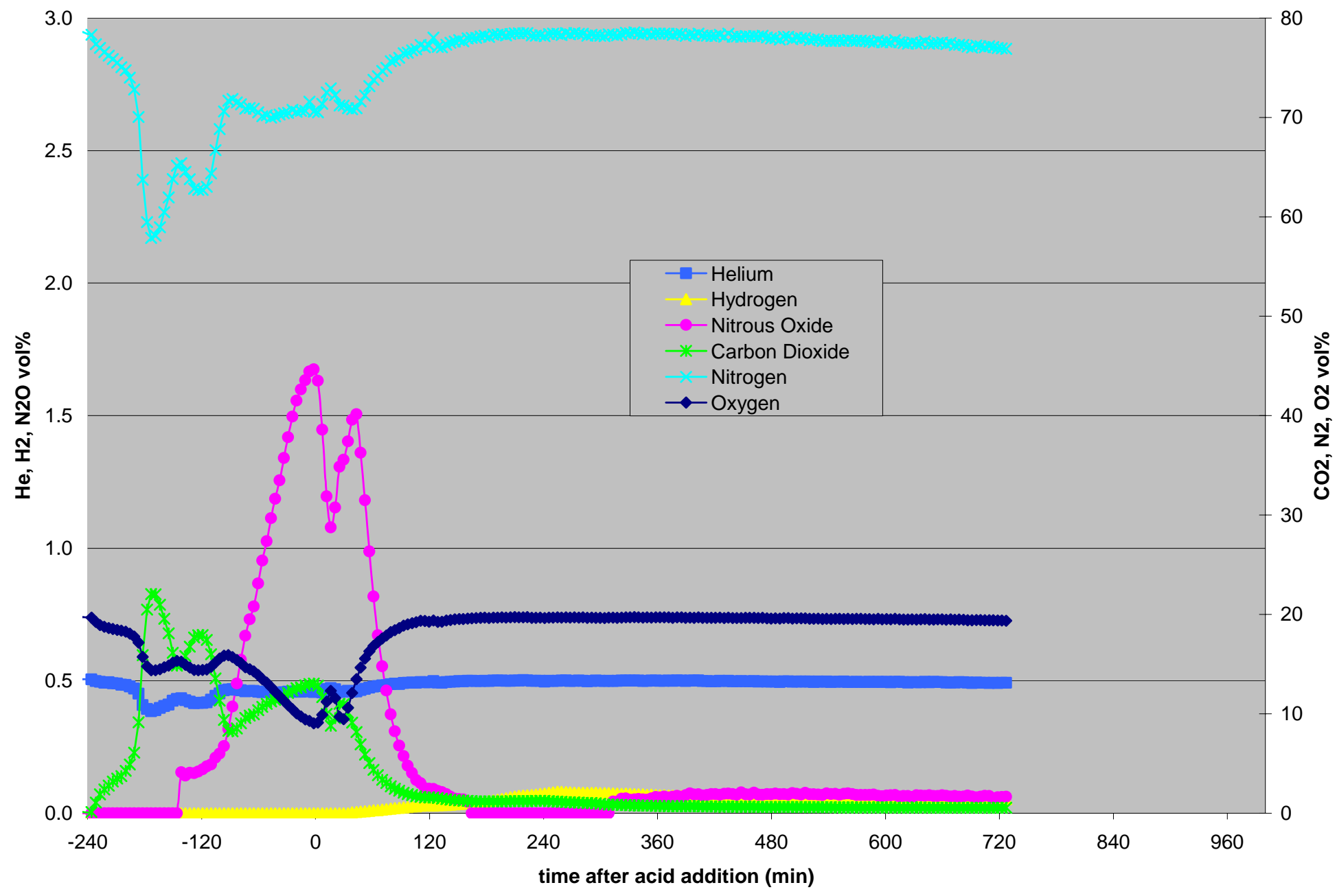




\section{APPENDIX B. ANALYTICAL DATA}

The Process Science Analytical Laboratory and Analytical Development personnel analyzed samples as requested. The sample results presented in this appendix:

Table B1 SB6-A and SB6-B Sludge Analytical Data (SRAT Receipt Sample)

Table B2 SB6-1 to SB6-6 SRAT Product Analytical Data

Table B3 SB6-1 to SB6-6 SME Product Analytical Data

Table B4 SB6-1 to SB6-6 SRAT Dewater Analytical Results

Table B5 SB6-1 to SB6-6 SRAT Intermediate Slurry Sample Analytical Results

Table B6

Table B7

Table B8

SB6-1 to SB6-6 SRAT Intermediate Centrifuged Sample Analytical Results

AD Mercury Analytical Results, wt \% total solids

AD Ammonium and Carbon Analytical Results on SRAT and SME product

NOTE: The following protocol was used to number the samples from the SRAT runs: 09-SB6-X-xxxx-A/B where:

$09=\quad$ year (not included in many tables since this number is the same for all samples in study)

SB6-x $=\quad$ Run number

$\mathrm{xxxx}=$ Unique sample number

$\mathrm{A} / \mathrm{B}=$ Analytical replicate 
Table B1

SB6-A and SB6-B Sludge Slurry Analysis

Process Science Analytical Laboratory

Customer: Dan Lambert

Date: $3 / 25 / 09$

Sample ID: 09-SB6-A-2665, 09-SB6-B-2665 (5) and 09-SB6-B-2665 (6) Lab ID: 09-0139 09-0194 and 09-0195

elemental wt\%-calcined 1100C

\begin{tabular}{|c|c|c|c|c|c|c|c|c|c|c|c|c|c|c|}
\hline Sample Description & Sample ID & Lab ID & Al & Ba & Ca & $\mathrm{Ce}$ & Cr & $\underline{\mathrm{Cu}}$ & $\mathbf{F e}$ & $\underline{\mathbf{K}}$ & $\underline{\mathbf{L a}}$ & Mg & Mn & $\mathrm{Na}$ \\
\hline SB6A Simulant & 09-SB6-A-2665 (A) & 09-0139 & 15.3 & 0.214 & 2.08 & 0.180 & 0.248 & 0.086 & 18.4 & $0 . \overline{104}$ & 0.093 & 1.52 & 6.70 & 14.4 \\
\hline SB6A Simulant & 09-SB6-A-2665 (B) & 09-0139 & 15.2 & 0.218 & 2.10 & 0.180 & 0.253 & 0.082 & 18.2 & 0.101 & 0.093 & 1.49 & 6.77 & 14.5 \\
\hline SB6B Simulant & 09-SB6-B-2665 (5) (A) & 09-0194 & 14.9 & 0.215 & 2.20 & 0.188 & 0.251 & 0.093 & 18.3 & 0.098 & 0.093 & 1.56 & 7.01 & 15.4 \\
\hline SB6B Simulant & 09-SB6-B-2665 (5) (B) & 09-0194 & 14.9 & 0.215 & 2.20 & 0.189 & 0.252 & 0.096 & 18.3 & 0.097 & 0.092 & 1.56 & 7.01 & 15.2 \\
\hline SB6B Simulant & 09-SB6-B-2665 (6) (A) & 09-01 & 14.6 & 0.217 & 2.15 & 0.191 & 0.256 & 0.100 & 18.2 & 0.096 & 0.093 & 1.55 & 6.90 & 15.2 \\
\hline \multirow[t]{2}{*}{ SB6B Simulant } & 09-SB6-B-2665 (6) (B) & 09-0195 & 14.7 & 0.215 & 2.15 & 0.188 & 0.254 & 0.089 & 18.4 & 0.096 & 0.092 & 1.58 & 6.99 & 15.1 \\
\hline & oxide wt $\%$ - calcined $1100 \mathrm{C}$ & Lab ID & $\mathrm{Al} 2 \mathrm{O} 3$ & $\underline{\mathrm{BaO}}$ & $\underline{\mathrm{CaO}}$ & $\underline{\mathrm{CeO} 2}$ & $\underline{\mathrm{Cr} 2 \mathrm{O} 3}$ & $\underline{\mathrm{CuO}}$ & $\underline{\mathrm{Fe} 2 \mathrm{O} 3}$ & $\underline{\mathrm{K} 2 \mathrm{O}}$ & $\underline{\mathrm{La} 2 \mathrm{O} 3}$ & $\underline{\mathrm{MgO}}$ & $\underline{\mathrm{MnO} 2}$ & $\underline{\mathrm{Na} 2 \mathrm{O}}$ \\
\hline SB6A Simulant & 09-SB6-A-2665 (A) & 09-0139 & 28.8 & 0.240 & 2.91 & 0.221 & 0.362 & 0.108 & 26.4 & 0.125 & 0.109 & 2.52 & 10.6 & 19.4 \\
\hline SB6A Simulant & 09-SB6-A-2665 (B) & 09-0139 & 28.7 & 0.244 & 2.94 & 0.221 & 0.369 & & 26.0 & 0.121 & & 2.47 & 10.7 & 19.6 \\
\hline SB6B Simulant & & & 28.2 & & 3.08 & & & & 26 & 0.118 & & 2.59 & & 20.8 \\
\hline SB6B Simulant & 09-SB6-B-2665 (5) (B) & 09-0194 & 28.1 & 0.241 & 3.07 & 0.232 & 0.368 & 0.120 & 26.2 & 0.117 & 0.108 & 2.59 & 11.1 & 20.6 \\
\hline SB6B Simulant & 09-SB6-B-2665 (6) (A) & 09-0195 & 27.6 & 0.243 & 3.01 & 0.235 & 0.374 & 0.125 & 26.0 & 0.115 & 0.108 & 2.58 & 10.9 & 20.5 \\
\hline SB6B Simulant & 09-SB6-B-2665 (6) (B) & 09-0195 & 27.7 & 0.241 & 3.01 & 0.231 & 0.371 & 0.112 & 26.3 & 0.116 & 0.108 & 2.62 & 11.1 & 20.4 \\
\hline
\end{tabular}

elemental wt\%-calcined $1100 \mathrm{C}$

\begin{tabular}{|c|c|c|c|c|c|c|c|c|c|c|c|}
\hline Sample Description & Sample ID & Lab ID_ & $\underline{\mathrm{Ni}}$ & $\underline{\mathrm{P}}$ & $\underline{\mathrm{Pb}}$ & $\underline{\mathrm{S}}$ & $\underline{\mathrm{Si}}$ & $\underline{\mathrm{Ti}}$ & $\underline{\underline{\mathrm{Zn}}}$ & $\underline{\mathrm{Zr}}$ & \\
\hline SB6A Simulant & 09-SB6-A-2665 (A) & 09-0139 & 3.82 & $<0.100$ & 0.012 & 0.311 & 0.504 & 0.020 & 0.153 & 0.358 & \\
\hline SB6A Simulant & 09-SB6-A-2665 (B) & 09-0139 & 3.87 & $<0.100$ & 0.013 & 0.306 & 0.500 & 0.020 & 0.156 & 0.360 & \\
\hline SB6B Simulant & 09-SB6-B-2665 (5) (A) & 09-0194 & 4.06 & $<0.100$ & 0.021 & 0.304 & 0.588 & 0.023 & 0.156 & 0.361 & \\
\hline SB6B Simulant & 09-SB6-B-2665 (5) (B) & 09-0194 & 4.01 & $<0.100$ & 0.021 & 0.304 & 0.622 & 0.020 & 0.154 & 0.361 & \\
\hline SB6B Simulant & 09-SB6-B-2665 (6) (A) & 09-0195 & 3.96 & $<0.100$ & 0.033 & 0.312 & 0.594 & 0.020 & 0.155 & 0.367 & \\
\hline \multirow[t]{2}{*}{ SB6B Simulant } & 09-SB6-B-2665 (6) (B) & 09-0195 & 4.04 & $<0.100$ & 0.032 & 0.314 & 0.588 & 0.020 & 0.156 & 0.361 & \\
\hline & oxide wt\% - calcined $1100 \mathrm{C}$ & Lab ID & $\underline{\mathrm{NiO}}$ & $\underline{\mathrm{P} 2 \mathrm{O} 5}$ & $\underline{\mathrm{PbO}}$ & $\underline{\mathrm{SO} 4}$ & $\underline{\mathrm{SiO} 2}$ & $\underline{\mathrm{TiO} 2}$ & $\underline{\mathrm{ZnO}}$ & $\underline{\mathrm{ZrO} 2}$ & Totals \\
\hline SB6A Simulant & 09-SB6-A-2665 (A) & 09-0139 & 4.85 & 0.000 & 0.013 & 0.933 & 1.08 & 0.000 & 0.190 & 0.483 & 99.3 \\
\hline SB6A Simulant & 09-SB6-A-2665 (B) & 09-0139 & 4.91 & 0.000 & 0.014 & 0.918 & 1.07 & 0.000 & 0.193 & 0.486 & 99.1 \\
\hline SB6B Simulant & 09-SB6-B-2665 (5) (A) & 09-0194 & 5.16 & 0.00 & 0.023 & 0.913 & 1.26 & 0.038 & 0.193 & 0.488 & 101 \\
\hline SB6B Simulant & 09-SB6-B-2665 (5) (B) & 09-0194 & 5.10 & 0.00 & 0.022 & 0.911 & 1.33 & 0.034 & 0.191 & 0.487 & 101 \\
\hline SB6B Simulant & 09-SB6-B-2665 (6) (A) & 09-0195 & 5.03 & 0.00 & 0.036 & 0.935 & 1.27 & 0.033 & 0.192 & 0.495 & 99.7 \\
\hline SB6B Simulant & 09-SB6-B-2665 (6) (B) & 09-0195 & 5.13 & 0.00 & 0.034 & 0.941 & 1.26 & 0.033 & 0.193 & 0.487 & 100 \\
\hline
\end{tabular}


SRNL-STI-2009-00413, REVISION 0

Units: $\mathrm{mg} / \mathrm{Kg}$

\begin{tabular}{|c|c|c|c|c|c|c|c|c|c|c|}
\hline Sample Description & $\underline{\text { Sample ID }}$ & $\underline{\text { Lab ID }}$ & $\underline{\mathrm{F}}$ & $\underline{\mathrm{Cl}}$ & $\underline{\mathrm{NO} 2}$ & $\underline{\mathrm{NO} 3}$ & $\underline{\text { SO4 }}$ & $\underline{\mathrm{HCO} 2}$ & $\underline{\mathrm{C} 2 \mathrm{O} 4}$ & $\underline{\mathrm{PO} 4}$ \\
\hline SB6A Simulant & 09-SB6-A-2665 (A) & $09-0139$ & $<100$ & 168 & 14000 & 8650 & 1180 & $<100$ & $<100$ & $<100$ \\
\hline SB6A Simulant & 09-SB6-A-2665 (B) & $09-0139$ & $<100$ & 170 & 14000 & 8760 & 1190 & $<100$ & $<100$ & $<100$ \\
\hline SB6B Simulant & 09-SB6-B-2665 (5) (A) & $09-0194$ & $<100$ & 191 & 13700 & 9130 & 1150 & $<100$ & $<100$ & $<100$ \\
\hline SB6B Simulant & 09-SB6-B-2665 (5) (B) & $09-0194$ & $<100$ & 190 & 13500 & 9080 & 1140 & $<100$ & $<100$ & $<100$ \\
\hline SB6B Simulant & 09-SB6-B-2665 (6) (A) & $09-0195$ & $<100$ & 191 & 13600 & 8940 & 1150 & $<100$ & $<100$ & $<100$ \\
\hline SB6B Simulant & 09-SB6-B-2665 (6) (B) & $09-0195$ & $<100$ & 191 & 13500 & 9010 & 1150 & $<100$ & $<100$ & $<100$ \\
\hline
\end{tabular}

Weight \% Solids Calculations

\begin{tabular}{|c|c|c|c|c|c|c|c|c|}
\hline Sample Description & Sample & $\underline{\mathrm{Lab}}$ ID & Total Solids & Insoluble Solids & Calcined Solids & $\begin{array}{l}\text { Soluble } \\
\text { Solids }\end{array}$ & $\frac{\text { Density, }}{\mathrm{g} / \mathrm{mL}}$ & $\mathrm{pH}$ \\
\hline SB6A Simulant & 09-SB6-A-2665 (A) & 09-0139 & $17.7 \%$ & $11.2 \%$ & $13.0 \%$ & $6.50 \%$ & 1.14 & 12.7 \\
\hline SB6A Simulant & 09-SB6-A-2665 (B) & 09-0139 & $17.7 \%$ & $11.0 \%$ & $12.9 \%$ & $6.76 \%$ & & \\
\hline SB6B Simulant & 09-SB6-B-2665 (5) (A) & 09-0194 & $20.0 \%$ & $13.5 \%$ & $14.7 \%$ & $6.48 \%$ & 1.07 & 12.7 \\
\hline SB6B Simulant & 09-SB6-B-2665 (5) (B) & 09-0194 & $20.0 \%$ & $13.4 \%$ & $14.7 \%$ & $6.60 \%$ & & \\
\hline SB6B Simulant & 09-SB6-B-2665 (6) (A) & $09-0195$ & $19.9 \%$ & $13.3 \%$ & $14.7 \%$ & $6.56 \%$ & 1.11 & 12.7 \\
\hline SB6B Simulant & 09-SB6-B-2665 (6) (B) & 09-0195 & $19.9 \%$ & $13.3 \%$ & $14.7 \%$ & $6.62 \%$ & & \\
\hline
\end{tabular}

Process Science Analytical Laboratory

Customer: Dan Lambert

Date: 3/13/09

Sample ID: 09-SB6-A-2665

Lab ID: 09-0139

Comments: Auto Titration

Units: mmol/gram

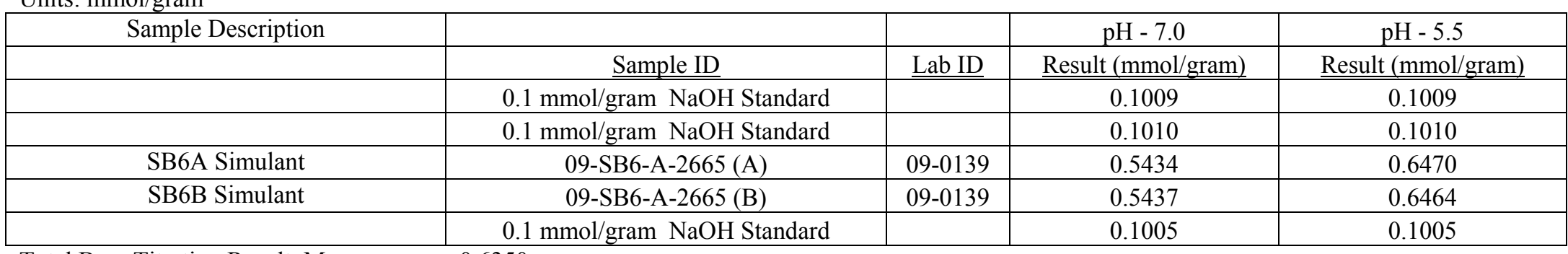

Total Base Titration Result, M 0.6350 
SRNL-STI-2009-00413, REVISION 0

\begin{tabular}{|c|c|c|c|c|c|c|c|c|c|c|c|c|c|c|}
\hline Sample Description & supernate $(\mathrm{mg} / \mathrm{L})$ & & $\underline{\mathrm{Al}}$ & $\underline{\mathrm{Ba}}$ & $\underline{\mathrm{Ca}}$ & $\underline{\mathrm{Ce}}$ & $\underline{\mathrm{Cr}}$ & $\underline{\mathrm{Cu}}$ & $\underline{\mathrm{Fe}}$ & $\underline{\mathrm{K}}$ & $\underline{\mathrm{La}}$ & $\underline{\mathrm{Mg}}$ & $\underline{\mathrm{Mn}}$ & $\underline{\mathrm{Na}}$ \\
\hline SB6A Simulant & 09-SB6-A-2665 (A) & 09-0139 & 2690 & $<0.100$ & 5.87 & $<0.100$ & 13.5 & $<0.100$ & $<0.100$ & 235 & $<0.100$ & $<\overline{0.100}$ & $<\overline{0.100}$ & 23000 \\
\hline SB6A Simulant & 09-SB6-A-2665 (B) & 09-0139 & 2700 & $<0.100$ & 5.86 & $<0.100$ & 13.6 & $<0.100$ & $<0.100$ & 233 & $<0.100$ & $<0.100$ & $<0.100$ & 22900 \\
\hline
\end{tabular}

\begin{tabular}{|c|c|c|c|c|c|c|c|c|c|c|}
\hline Sample Description & supernate $(\mathrm{mg} / \mathrm{L})$ & & $\mathrm{Ni}$ & $\underline{\mathrm{P}}$ & $\underline{\mathrm{Pb}}$ & $\underline{\mathrm{S}}$ & $\underline{\mathrm{Si}}$ & $\underline{\mathrm{Ti}}$ & $\underline{\mathrm{Zn}}$ & $\underline{\mathrm{Zr}}$ \\
\hline SB6A Simulant & 09-SB6-A-2665 (A) & 09-0139 & $<0.100$ & $<1.00$ & $<0.100$ & 408 & $<0.100$ & $<0.100$ & $<0.100$ & $<0.100$ \\
\hline SB6A Simulant & 09-SB6-A-2665 (B) & 09-0139 & $<0.100$ & $<1.00$ & $<0.100$ & 407 & $<0.100$ & $<0.100$ & $<0.100$ & $<0.100$ \\
\hline
\end{tabular}

AD Sample Results (SB6-B TIC values calculated from SB6a results)

\begin{tabular}{|c|c|c|c|c|c|c|c|c|}
\hline Sample Id & User SampleID & LIMS Method & $\begin{array}{c}\text { Total } \\
\text { Carbon }\end{array}$ & $\begin{array}{c}\text { Inorganic } \\
\text { Carbon }\end{array}$ & $\begin{array}{l}\text { Organic } \\
\text { Carbon }\end{array}$ & $\begin{array}{l}1 \text { Sigma } \\
\% \text { Unc }\end{array}$ & Units & Rv \\
\hline \multicolumn{9}{|l|}{ Slurry } \\
\hline 300258058 & 09_SB6_A_2667A & TIC/TOC (B154) & 133 & 118 & 15 & 10 & $\mathrm{mg} \mathrm{C} / \mathrm{mL}$ & 1 \\
\hline 300258059 & 09 SB6 A 2667B & TIC/TOC (B154) & 150 & 121 & 29 & 10 & $\mathrm{mg} \mathrm{C} / \mathrm{mL}$ & \\
\hline 300258060 & 09 SB6 A 2667C & TIC/TOC (B154) & 173 & 125 & 48 & 10 & $\mathrm{mg} \mathrm{C} / \mathrm{mL}$ & 1 \\
\hline Supernate & & & 1290 & 1270 & 20 & & & \\
\hline 300258061 & 09_SB6_A_2668A & TIC/TOC (B154) & 1280 & 1270 & 10 & 10 & $\mathrm{mg} \mathrm{C} / \mathrm{mL}$ & 1 \\
\hline 300258062 & 09_SB6_A_2668B & TIC/TOC (B154) & 1290 & 1270 & 20 & 10 & $\mathrm{mg} \mathrm{C} / \mathrm{mL}$ & 1 \\
\hline 300258063 & 09_SB6_A_2668C & TIC/TOC (B154) & 1300 & 1280 & 20 & 10 & $\mathrm{mg} \mathrm{C} / \mathrm{mL}$ & 1 \\
\hline
\end{tabular}

\begin{tabular}{|l|l|c|c|c|c|}
\hline & & & & & \\
Sample Id & User SampleID & Sample Mass, g & Total Mass, g & Corrected TIC & Carbonate \\
\hline 300258058 & 09_SB6_A_2667A & 2.002 & 40.084 & 2360 & 11,800 \\
\hline 300258059 & 09_SB6_A_2667B & 2.097 & 40.14 & 2320 & 11,600 \\
\hline 300258060 & 09_SB6_A_2667C & 2.018 & 40.031 & 2480 & 12,400 \\
\hline
\end{tabular}


Table B2

PSAL SRAT Product Analytical Results

Process Science Analytical Laboratory

Customer: Dan Lambert

Date: 4/2/09, 4/6/09

Sample ID: SB6-1-2677, SB6-4-2694, SB6-2-2711, SB6-3-2729, SB6-5-2748 and SB6-6-2765 (SRAT Products)

Lab ID: 09-0165, 09-0168, 09-0217 and 09-0218

elemental wt\%-calcined $1100 \mathrm{C}$

\begin{tabular}{|c|c|c|c|c|c|c|c|c|c|c|c|c|c|}
\hline Sample Description & Sample ID & Lab ID_ & $\underline{\mathrm{Al}}$ & $\underline{\mathrm{Ba}}$ & $\underline{\mathrm{Ca}}$ & $\underline{\mathrm{Ce}}$ & $\underline{\mathrm{Cr}}$ & $\underline{\mathrm{Cu}}$ & $\underline{\mathrm{Fe}}$ & $\underline{\mathrm{K}}$ & $\underline{\underline{\mathrm{La}}}$ & $\underline{\mathrm{Mg}}$ & $\underline{\mathrm{Mn}}$ \\
\hline SB6-1 SRAT Product $(100 \%)$ & SB6-1-2677 (A) & $09-0165$ & 14.5 & 0.211 & 2.03 & 0.189 & 0.262 & 0.091 & 17.2 & 0.122 & 0.092 & 1.44 & 6.49 \\
\hline SB6-1 SRAT Product $(100 \%)$ & SB6-1-2677 (B) & $09-0165$ & 14.4 & 0.213 & 1.98 & 0.188 & 0.259 & 0.097 & 17.1 & 0.119 & 0.092 & 1.42 & 6.45 \\
\hline SB6-2 SRAT Product $(90 \%)$ & SB6-2-2711 (A) & 09-0167 & 14.5 & 0.203 & 2.00 & 0.186 & 0.259 & 0.097 & 17.2 & 0.088 & 0.091 & 1.44 & 6.51 \\
\hline SB6-2 SRAT Product (90\%) & SB6-2-2711 (B) & $09-0167$ & 14.5 & 0.203 & 2.07 & 0.186 & 0.259 & 0.087 & 17.1 & 0.090 & 0.091 & 1.43 & 6.47 \\
\hline SB6-3 SRAT Product (120\%) & SB6-3-2729 (A) & 09-0168 & 14.5 & 0.204 & 2.02 & 0.187 & 0.258 & 0.043 & 17.2 & 0.090 & 0.091 & 1.41 & 6.23 \\
\hline SB6-3 SRAT Product $(120 \%)$ & SB6-3-2729 (B) & 09-0168 & 14.6 & 0.205 & 2.07 & 0.187 & 0.259 & 0.033 & 17.2 & 0.093 & 0.092 & 1.42 & 6.2 \\
\hline SB6-4 SRAT Product $(150 \%)$ & SB6-4-2694 (A) & 09-0166 & 14.7 & 0.223 & 1.96 & 0.188 & 0.263 & 0.030 & 17.4 & 0.134 & 0.092 & 1.39 & 6.50 \\
\hline SB6-4 SRAT Product $(150 \%)$ & SB6-4-2694 (B) & $09-0166$ & 14.9 & 0.226 & 1.94 & 0.190 & 0.266 & 0.033 & 17.6 & 0.134 & 0.093 & 1.39 & 6.49 \\
\hline SB6-5 SRAT Product $(100 \%)$ & SB6-5-2748 (A) & 09-0217 & 14.5 & 0.211 & 2.08 & 0.194 & 0.261 & 0.096 & 17.6 & 0.095 & 0.095 & 1.49 & 6.6 \\
\hline SB6-5 SRAT Product $(100 \%)$ & SB6-5-2748 (B) & $09-0217$ & 14.3 & 0.208 & 2.06 & 0.193 & 0.260 & 0.089 & 17.4 & 0.095 & 0.094 & 1.48 & 6.6 \\
\hline SB6-6 SRAT Product $(120 \%)$ & SB6-6-2765 (A) & 09-0218 & 14.3 & 0.213 & 2.05 & 0.193 & 0.262 & 0.066 & 17.4 & 0.084 & 0.094 & 1.46 & 6.5 \\
\hline SB6-6 SRAT Product (120\%) & SB6-6-2765 (B) & $09-0218$ & 14.4 & 0.209 & 2.07 & 0.192 & 0.257 & 0.057 & 17.3 & 0.087 & 0.094 & 1.46 & 6.4 \\
\hline
\end{tabular}

\begin{tabular}{|c|c|c|c|c|c|c|c|c|c|c|c|c|c|}
\hline Sample Description & oxide wt\% - calcined 1100C & & $\mathrm{A} 12 \mathrm{O} 3$ & $\underline{\mathrm{BaO}}$ & $\underline{\mathrm{CaO}}$ & $\underline{\mathrm{CeO} 2}$ & $\mathrm{Cr} 2 \mathrm{O} 3$ & $\underline{\mathrm{CuO}}$ & $\underline{\mathrm{Fe} 2 \mathrm{O} 3}$ & $\underline{\mathrm{K} 2 \mathrm{O}}$ & $\underline{\mathrm{La} 2 \mathrm{O} 3}$ & $\underline{\mathrm{MgO}}$ & $\underline{\mathrm{MnO}}$ \\
\hline SB6-1 SRAT Product $(100 \%)$ & SB6-1-2677 (A) & $09-0165$ & 27.5 & 0.236 & 2.84 & 0.232 & 0.383 & 0.113 & 24.6 & 0.147 & 0.108 & 2.40 & 10.3 \\
\hline SB6-1 SRAT Product $(100 \%)$ & SB6-1-2677 (B) & $09-0165$ & 27.1 & 0.238 & 2.78 & 0.231 & 0.378 & 0.121 & 24.5 & 0.143 & 0.107 & 2.36 & 10. \\
\hline SB6-2 SRAT Product (90\%) & SB6-4-2694 (A) & $09-0166$ & 27.8 & 0.250 & 2.74 & 0.231 & 0.383 & 0.038 & 24.9 & 0.161 & 0.108 & 2.31 & 10. \\
\hline SB6-2 SRAT Product $(90 \%)$ & SB6-4-2694 (B) & 09-0166 & 28.1 & 0.253 & 2.72 & 0.233 & 0.388 & 0.042 & 25.1 & 0.160 & 0.108 & 2.31 & 10. \\
\hline SB6-3 SRAT Product $(120 \%)$ & SB6-2-2711 (A) & 09-0167 & 27.3 & 0.227 & 2.80 & 0.229 & 0.378 & 0.122 & 24.6 & 0.106 & 0.106 & 2.39 & 10. \\
\hline SB6-3 SRAT Product $(120 \%)$ & SB6-2-2711 (B) & $09-0167$ & 27.4 & 0.227 & 2.90 & 0.229 & 0.378 & 0.109 & 24.5 & 0.108 & 0.107 & 2.38 & 10. \\
\hline SB6-4 SRAT Product $(150 \%)$ & SB6-3-2729 (A) & 09-0168 & 27.4 & 0.228 & 2.83 & 0.230 & 0.377 & 0.053 & 24.5 & 0.108 & 0.107 & 2.34 & 9.8 \\
\hline SB6-4 SRAT Product $(150 \%)$ & SB6-3-2729 (B) & $09-0168$ & 27.7 & 0.229 & 2.89 & 0.230 & 0.379 & 0.041 & 24.6 & 0.112 & 0.107 & 2.36 & 9. \\
\hline SB6-5 SRAT Product $(100 \%)$ & SB6-5-2748 (A) & 09-0217 & 27.3 & 0.236 & 2.91 & 0.238 & 0.381 & 0.120 & 25.1 & 0.114 & 0.111 & 2.47 & 10 \\
\hline SB6-5 SRAT Product (100\%) & SB6-5-2748 (B) & $09-0217$ & 27.1 & 0.233 & 2.88 & 0.237 & 0.379 & 0.112 & 24.9 & 0.114 & 0.110 & 2.45 & 10 \\
\hline SB6-6 SRAT Product $(120 \%)$ & SB6-6-2765 (A) & $09-0218$ & 27.1 & 0.239 & 2.86 & 0.237 & 0.382 & 0.083 & 24.9 & 0.101 & 0.110 & 2.43 & 10 \\
\hline SB6-6 SRAT Product $(120 \%)$ & SB6-6-2765 (B) & 09-0218 & 27.2 & 0.234 & 2.89 & 0.236 & 0.376 & 0.071 & 24.8 & 0.105 & 0.110 & 2.42 & 10 \\
\hline
\end{tabular}


SRNL-STI-2009-00413, REVISION 0

elemental wt\%-calcined $1100 \mathrm{C}$

\begin{tabular}{|c|c|c|c|c|c|c|c|c|c|c|c|c|c|}
\hline Sample Description & Sample ID & Lab ID_ & $\underline{\mathrm{Ni}}$ & $\underline{\mathrm{P}}$ & $\underline{\mathrm{Pb}}$ & $\underline{\mathrm{Pd}}$ & $\underline{\mathrm{Rh}}$ & $\underline{\mathrm{S}}$ & $\underline{\mathrm{Si}}$ & $\underline{\mathrm{Ti}}$ & $\underline{\mathrm{Zn}}$ & $\underline{\mathrm{Zr}}$ & \\
\hline SB6-1 SRAT Product $(100 \%)$ & SB6-1-2677 (A) & $09-0165$ & 3.76 & $<0.010$ & 0.017 & $<0.010$ & $<0.100$ & 0.332 & 0.599 & 0.020 & 0.148 & 0.358 & \\
\hline SB6-1 SRAT Product $(100 \%)$ & SB6-1-2677 (B) & $09-0165$ & 3.74 & $<0.010$ & 0.021 & $<0.010$ & $<0.100$ & 0.337 & 0.595 & 0.019 & 0.148 & 0.357 & \\
\hline SB6-2 SRAT Product (90\%) & SB6-2-2711 (A) & 09-0167 & 3.76 & $<0.010$ & 0.014 & $<0.010$ & $<0.100$ & 0.325 & 0.615 & 0.019 & 0.147 & 0.359 & \\
\hline SB6-2 SRAT Product $(90 \%)$ & SB6-2-2711 (B) & $09-0167$ & 3.74 & $<0.010$ & 0.011 & $<0.010$ & $<0.100$ & 0.339 & 0.605 & 0.019 & 0.159 & 0.359 & \\
\hline SB6-3 SRAT Product $(120 \%)$ & SB6-3-2729 (A) & $09-0168$ & 3.75 & $<0.010$ & 0.016 & $<0.010$ & $<0.100$ & 0.328 & 0.583 & 0.018 & 0.148 & 0.353 & \\
\hline SB6-3 SRAT Product $(120 \%)$ & SB6-3-2729 (B) & 09-0168 & 3.77 & $<0.010$ & 0.016 & $<0.010$ & $<0.100$ & 0.346 & 0.584 & 0.019 & 0.154 & 0.363 & \\
\hline SB6-4 SRAT Product $(150 \%)$ & SB6-4-2694 (A) & 09-0166 & 3.78 & $<0.010$ & 0.046 & $<0.010$ & $<0.100$ & 0.334 & 0.593 & 0.019 & 0.155 & 0.370 & \\
\hline SB6-4 SRAT Product $(150 \%)$ & SB6-4-2694 (B) & 09-0166 & 3.78 & $<0.010$ & 0.047 & $<0.010$ & $<0.100$ & 0.336 & 0.593 & 0.020 & 0.151 & 0.371 & \\
\hline SB6-5 SRAT Product (100\%) & SB6-5-2748 (A) & $09-0217$ & 3.83 & $<0.100$ & 0.022 & $<0.010$ & $<0.100$ & 0.314 & 0.615 & 0.019 & 0.152 & 0.374 & \\
\hline SB6-5 SRAT Product $(100 \%)$ & SB6-5-2748 (B) & $09-0217$ & 3.80 & $<0.100$ & 0.021 & $<0.010$ & $<0.100$ & 0.322 & 0.622 & 0.019 & 0.152 & 0.371 & \\
\hline SB6-6 SRAT Product $(120 \%)$ & SB6-6-2765 (A) & 09-0218 & 3.79 & $<0.100$ & 0.021 & $<0.010$ & $<0.100$ & 0.314 & 0.625 & 0.020 & 0.151 & 0.371 & \\
\hline SB6-6 SRAT Product $(120 \%)$ & SB6-6-2765 (B) & 09-0218 & 3.78 & $<0.100$ & 0.020 & $<0.010$ & $<0.100$ & 0.313 & 0.619 & 0.019 & 0.149 & 0.369 & \\
\hline Sample Description & oxide wt\% - calcined 1100C & & $\underline{\mathrm{NiO}}$ & $\underline{\mathrm{P} 2 \mathrm{O} 5}$ & $\underline{\mathrm{PbO}}$ & $\underline{\mathrm{PdO}}$ & $\underline{\mathrm{RhO} 2}$ & $\underline{\mathrm{SO} 4}$ & $\underline{\mathrm{SiO} 2}$ & $\underline{\mathrm{TiO} 2}$ & $\underline{\mathrm{ZnO}}$ & $\underline{\mathrm{ZrO} 2}$ & $\underline{\text { Totals }}$ \\
\hline SB6-1 SRAT Product $(100 \%)$ & SB6-1-2677 (A) & $09-0165$ & 4.78 & & 0.018 & & & 0.996 & 1.28 & 0.033 & 0.184 & 0.483 & 98.5 \\
\hline SB6-1 SRAT Product $(100 \%)$ & SB6-1-2677 (B) & $09-0165$ & 4.75 & & 0.023 & & & 1.01 & 1.27 & 0.031 & 0.184 & 0.482 & 97.8 \\
\hline SB6-2 SRAT Product $(90 \%)$ & SB6-2-2711 (A) & 09-0167 & 4.78 & & 0.015 & & & 0.976 & 1.32 & 0.031 & 0.182 & 0.484 & 98.3 \\
\hline SB6-2 SRAT Product (90\%) & SB6-2-2711 (B) & 09-0167 & 4.75 & & 0.012 & & & 1.02 & 1.29 & 0.031 & 0.197 & 0.485 & 97.9 \\
\hline SB6-3 SRAT Product $(120 \%)$ & SB6-3-2729 (A) & 09-0168 & 4.76 & & 0.018 & & & 0.985 & 1.25 & 0.031 & 0.184 & 0.477 & 97.8 \\
\hline SB6-3 SRAT Product $(120 \%)$ & SB6-3-2729 (B) & 09-0168 & 4.79 & & 0.017 & & & 1.04 & 1.25 & 0.032 & 0.191 & 0.491 & 98.3 \\
\hline SB6-4 SRAT Product $(150 \%)$ & SB6-4-2694 (A) & 09-0166 & 4.81 & & 0.049 & & & 1.00 & 1.27 & 0.032 & 0.192 & 0.500 & 98.1 \\
\hline SB6-4 SRAT Product (150\%) & SB6-4-2694 (B) & 09-0166 & 4.80 & & 0.050 & & & 1.01 & 1.27 & 0.033 & 0.188 & 0.501 & 98.9 \\
\hline SB6-5 SRAT Product $(100 \%)$ & SB6-5-2748 (A) & $09-0217$ & 4.86 & & 0.024 & & & 0.942 & 1.32 & 0.032 & 0.189 & 0.504 & 98.4 \\
\hline SB6-5 SRAT Product $(100 \%)$ & SB6-5-2748 (B) & 09-0217 & 4.82 & & 0.023 & & & 0.966 & 1.33 & 0.032 & 0.188 & 0.501 & 97.6 \\
\hline SB6-6 SRAT Product (120\%) & SB6-6-2765 (A) & 09-0218 & 4.82 & & 0.023 & & & 0.943 & 1.34 & 0.033 & 0.187 & 0.501 & 97.5 \\
\hline SB6-6 SRAT Product $(120 \%)$ & SB6-6-2765 (B) & 09-0218 & 4.80 & & 0.022 & & & 0.938 & 1.32 & 0.032 & 0.185 & 0.498 & 97.9 \\
\hline
\end{tabular}


SRNL-STI-2009-00413, REVISION 0

Units: $\mathrm{mg} / \mathrm{Kg}$

\begin{tabular}{|c|c|c|c|c|c|c|c|c|c|c|}
\hline Sample Description & Sample ID & $\underline{\text { Lab ID }}$ & $\underline{F}$ & $\underline{\mathrm{Cl}}$ & $\underline{\mathrm{NO} 2}$ & $\mathrm{NO3}$ & $\underline{\mathrm{SO} 4}$ & $\underline{\mathrm{HCO} 2}$ & $\mathrm{C} 2 \mathrm{O} 4$ & PO4 \\
\hline SB6-1 SRAT Product $(100 \%)$ & SB6-1-2677 (A) & $09-0165$ & $<100$ & 395 & 201 & 27100 & $<100$ & $\overline{54500}$ & $<100$ & $<100$ \\
\hline SB6-1 SRAT Product (100\%) & SB6-1-2677 (B) & 09-0165 & $<100$ & 392 & 200 & 27000 & $<100$ & 54800 & $<100$ & $<100$ \\
\hline SB6-2 SRAT Product (90\%) & SB6-2-2711 (A) & 09-0167 & $<100$ & 361 & 1940 & 24600 & $<100$ & 52900 & $<100$ & $<100$ \\
\hline SB6-2 SRAT Product $(90 \%)$ & SB6-2-2711 (B) & 09-0167 & $<100$ & 359 & 1980 & 24700 & $<100$ & 52200 & $<100$ & $<100$ \\
\hline SB6-3 SRAT Product (120\%) & SB6-3-2729 (A) & 09-0168 & $<100$ & 350 & $<100$ & 31800 & 841 & 57500 & $<100$ & $<100$ \\
\hline SB6-3 SRAT Product $(120 \%)$ & SB6-3-2729 (B) & 09-0168 & $<100$ & 348 & $<100$ & 32000 & 761 & 57700 & $<100$ & $<100$ \\
\hline SB6-4 SRAT Product (150\%) & SB6-4-2694 (A) & 09-0166 & $<100$ & 334 & $<100$ & 37700 & 237 & 67100 & $<100$ & $<100$ \\
\hline SB6-4 SRAT Product (150\%) & SB6-4-2694 (B) & 09-0166 & $<100$ & 336 & $<100$ & 37700 & 275 & 67000 & $<100$ & $<100$ \\
\hline SB6-5 SRAT Product (100\%) & SB6-5-2748 (A) & 09-0217 & $<100$ & 364 & 521 & 24300 & $<100$ & 52700 & $<100$ & $<100$ \\
\hline SB6-5 SRAT Product (100\%) & SB6-5-2748 (B) & 09-0217 & $<100$ & 359 & 514 & 24200 & $<100$ & 52100 & $<100$ & $<100$ \\
\hline SB6-6 SRAT Product (120\%) & SB6-6-2765 (A) & 09-0218 & $<100$ & 331 & $<100$ & 29300 & $<100$ & 56800 & $<100$ & $<100$ \\
\hline SB6-6 SRAT Product $(120 \%)$ & SB6-6-2765 (B) & $09-0218$ & $<100$ & 330 & $<100$ & 29400 & $<100$ & 57000 & $<100$ & $<100$ \\
\hline
\end{tabular}

Weight \% Solids Calculations, Density, $\mathrm{pH}$

\begin{tabular}{|c|c|c|c|c|c|c|c|c|}
\hline & & & & Insoluble & $\mathrm{Wt} \%$ & Soluble & & \\
\hline Sample Description & Sample & $\underline{\mathrm{Lab} I D}$ & Total Solids & Solids & Calcined & Solids & Density & $\mathrm{pH}$ \\
\hline SB6-1 SRAT Product $(100 \%)$ & SB6-1-2677 (A) & $09-0165$ & $26.1 \%$ & $14.6 \%$ & $16.1 \%$ & $11.5 \%$ & 1.14 & 7.55 \\
\hline SB6-1 SRAT Product $(100 \%)$ & SB6-1-2677 (B) & $09-0165$ & $26.1 \%$ & $14.7 \%$ & $16.2 \%$ & $11.5 \%$ & & \\
\hline SB6-2 SRAT Product (90\%) & SB6-2-2711 (A) & 09-0167 & $26.3 \%$ & $15.6 \%$ & $16.6 \%$ & $10.8 \%$ & 1.18 & 7.57 \\
\hline SB6-2 SRAT Product (90\%) & SB6-2-2711 (B) & $09-0167$ & $26.3 \%$ & $15.9 \%$ & $16.5 \%$ & $10.4 \%$ & & \\
\hline SB6-3 SRAT Product $(120 \%)$ & SB6-3-2729 (A) & $09-0168$ & $25.3 \%$ & $13.0 \%$ & $15.2 \%$ & $12.3 \%$ & 1.19 & 5.79 \\
\hline SB6-3 SRAT Product $(120 \%)$ & SB6-3-2729 (B) & 09-0168 & $25.3 \%$ & $12.9 \%$ & $15.2 \%$ & $12.4 \%$ & & \\
\hline SB6-4 SRAT Product (150\%) & SB6-4-2694 (A) & $09-0166$ & $25.9 \%$ & $14.7 \%$ & $14.4 \%$ & $11.3 \%$ & 1.18 & 4.64 \\
\hline SB6-4 SRAT Product $(150 \%)$ & SB6-4-2694 (B) & $09-0166$ & $25.8 \%$ & $14.4 \%$ & $14.3 \%$ & $11.3 \%$ & & \\
\hline SB6-5 SRAT Product $(100 \%)$ & SB6-5-2748 (A) & 09-0217 & $25.9 \%$ & $15.1 \%$ & $16.2 \%$ & $10.9 \%$ & 1.19 & 6.20 \\
\hline SB6-5 SRAT Product $(100 \%)$ & SB6-5-2748 (B) & $09-0217$ & $25.9 \%$ & $15.1 \%$ & $16.2 \%$ & $10.9 \%$ & & \\
\hline SB6-6 SRAT Product (120\%) & SB6-6-2765 (A) & $09-0218$ & $25.2 \%$ & $13.4 \%$ & $15.2 \%$ & $11.9 \%$ & 1.18 & 7.45 \\
\hline SB6-6 SRAT Product $(120 \%)$ & SB6-6-2765 (B) & $09-0218$ & $25.2 \%$ & $13.3 \%$ & $15.2 \%$ & $11.9 \%$ & & \\
\hline
\end{tabular}


Table B3

PSAL SME Product Analytical Results

Process Science Analytical Laboratory

Customer: Dan Lambert

Date: 4/6/09

Sample ID: SB6-1-2684, SB6-4-2701, SB6-2-2719, SB6-3-2737 (SME Products)

Lab ID: 09-0190 and 09-0193

\begin{tabular}{|c|c|c|c|c|c|c|c|c|c|c|c|c|c|c|}
\hline Sample Description & Sample ID & Lab ID_ & $\underline{\mathrm{Al}}$ & $\underline{\mathrm{B}}$ & $\underline{\mathrm{Ba}}$ & $\underline{\mathrm{Ca}}$ & $\underline{\mathrm{Ce}}$ & $\underline{\mathrm{Cr}}$ & $\underline{\mathrm{Cu}}$ & $\underline{\mathrm{Fe}}$ & $\underline{\mathrm{K}}$ & $\underline{\mathrm{La}}$ & $\underline{\mathrm{Li}}$ & \\
\hline SB6-1 SME Product (100\%) & SB6-1-2684 (A) & 09-0190 & 5.74 & 1.60 & 0.085 & 0.739 & 0.071 & 0.105 & 0.044 & 6.55 & 0.095 & 0.032 & 2.19 & 0. \\
\hline SB6-1 SME Product (100\%) & SB6-1-2684 (B) & 09-0190 & 5.74 & 1.52 & 0.084 & 0.747 & 0.071 & 0.105 & 0.047 & 6.56 & 0.096 & 0.032 & 2.22 & 0 . \\
\hline SB6-2 SME Product (90\%) & SB6-2-2719 (A) & 09-0192 & 5.65 & 1.45 & 0.081 & 0.749 & 0.069 & 0.103 & 0.047 & 6.40 & 0.078 & 0.031 & 2.21 & 0. \\
\hline SB6-2 SME Product $(90 \%)$ & SB6-2-2719 (B) & 09-0192 & 5.69 & 1.42 & 0.081 & 0.754 & 0.069 & 0.104 & 0.042 & 6.43 & 0.076 & 0.032 & 2.17 & 0 . \\
\hline SB6-3 SME Product (120\%) & SB6-3-2737 (A) & 09-0193 & 5.57 & 1.44 & 0.081 & 0.718 & 0.068 & 0.102 & 0.031 & 6.29 & 0.078 & 0.031 & 2.24 & 0 . \\
\hline SB6-3 SME Product (120\%) & SB6-3-2737 (B) & 09-0193 & 5.60 & 1.49 & 0.082 & 0.729 & 0.069 & 0.102 & 0.030 & 6.32 & 0.079 & 0.031 & 2.24 & 0. \\
\hline SB6-4 SME Product (150\%) & SB6-4-2701 (A) & 09-0191 & 5.32 & 1.51 & 0.078 & 0.643 & 0.065 & 0.098 & 0.016 & 6.11 & 0.097 & 0.029 & 2.28 & 0. \\
\hline SB6-4 SME Product (150\%) & SB6-4-2701 (B) & 09-0191 & 5.29 & 1.49 & 0.078 & 0.645 & 0.065 & 0.102 & 0.026 & 6.04 & 0.096 & 0.029 & 2.31 & 0. \\
\hline Sample Description & oxide wt\% - calcined 1100C & & $\underline{\mathrm{A} 12 \mathrm{O} 3}$ & $\underline{\mathrm{B} 2 \mathrm{O} 3}$ & $\underline{\mathrm{BaO}}$ & $\underline{\mathrm{CaO}}$ & $\underline{\mathrm{CeO} 2}$ & $\underline{\mathrm{Cr} 2 \mathrm{O} 3}$ & $\underline{\mathrm{CuO}}$ & $\underline{\mathrm{Fe} 2 \mathrm{O} 3}$ & $\underline{\mathrm{K} 2 \mathrm{O}}$ & $\underline{\mathrm{La} 2 \mathrm{O} 3}$ & $\underline{\mathrm{Li} 2 \mathrm{O}}$ & $\underline{\underline{M}}$ \\
\hline SB6-1 SME Product (100\%) & SB6-1-2684 (A) & 09-0190 & 10.9 & 5.15 & 0.095 & 1.03 & 0.088 & 0.153 & 0.055 & 9.36 & $\overline{0.114}$ & 0.038 & 4.71 & 0 . \\
\hline SB6-1 SME Product (100\%) & SB6-1-2684 (B) & 09-0190 & 10.8 & 4.89 & 0.094 & 1.05 & 0.087 & 0.153 & 0.058 & 9.37 & 0.116 & 0.038 & 4.77 & 0 . \\
\hline SB6-2 SME Product (90\%) & SB6-2-2719 (A) & 09-0192 & 10.7 & 4.67 & 0.090 & 1.05 & 0.085 & 0.150 & 0.059 & 9.15 & 0.093 & 0.037 & 4.75 & 0 . \\
\hline SB6-2 SME Product (90\%) & SB6-2-2719 (B) & 09-0192 & 10.8 & 4.57 & 0.091 & 1.06 & 0.085 & 0.152 & 0.052 & 9.20 & 0.091 & 0.037 & 4.67 & 0 . \\
\hline SB6-3 SME Product (120\%) & SB6-3-2737 (B) & 09-0193 & 10.6 & 4.80 & 0.091 & 1.02 & 0.084 & 0.150 & 0.038 & 9.03 & 0.095 & 0.036 & 4.82 & 0 . \\
\hline SB6-4 SME Product (150\%) & SB6-4-2701 (A) & 09-0191 & 10.0 & 4.86 & 0.087 & 0.90 & 0.080 & 0.144 & 0.020 & 8.74 & 0.116 & 0.034 & 4.90 & 0 . \\
\hline SB6-4 SME Product (150\%) & SB6-4-2701 (B) & 09-0191 & 10.0 & 4.80 & 0.087 & 0.90 & 0.079 & 0.148 & 0.032 & 8.64 & 0.115 & 0.034 & 4.97 & 0 . \\
\hline
\end{tabular}


SRNL-STI-2009-00413, REVISION 0

elemental wt\%-calcined 1100C

\begin{tabular}{|c|c|c|c|c|c|c|c|c|c|c|c|c|c|}
\hline Sample Description & Sample ID & Lab ID & $\mathrm{Na}$ & $\underline{\mathrm{Ni}}$ & $\underline{P}$ & $\underline{\mathrm{Pb}}$ & $\underline{\mathrm{Pd}}$ & $\underline{\mathrm{Rh}}$ & $\underline{S}$ & $\underline{\mathrm{Si}}$ & $\underline{\mathrm{Ti}}$ & $\underline{\mathrm{Zn}}$ & $\underline{\mathrm{Zr}}$ \\
\hline SB6-1 SME Product (100\%) & SB6-1-2684 (A) & 09-0190 & 9.47 & 1.40 & $<0.010$ & 0.055 & $<0.010$ & $<0.100$ & 0.104 & 23.0 & 0.046 & 0.055 & 0.224 \\
\hline SB6-1 SME Product (100\%) & SB6-1-2684 (B) & 09-0190 & 9.47 & 1.40 & $<0.010$ & 0.053 & $<0.010$ & $<0.100$ & 0.107 & 23.0 & 0.047 & 0.059 & 0.224 \\
\hline SB6-2 SME Product (90\%) & SB6-2-2719 (A) & 09-0192 & 9.61 & 1.37 & $<0.010$ & 0.052 & $<0.010$ & $<0.100$ & 0.088 & 23.2 & 0.045 & 0.053 & 0.221 \\
\hline SB6-2 SME Product (90\%) & SB6-2-2719 (B) & 09-0192 & 9.56 & 1.39 & $<0.010$ & 0.052 & $<0.010$ & $<0.100$ & 0.087 & 23.2 & 0.046 & 0.055 & 0.223 \\
\hline SB6-3 SME Product (120\%) & SB6-3-2737 (A) & 09-0193 & 9.35 & 1.38 & $<0.010$ & 0.053 & $<0.010$ & $<0.100$ & 0.090 & 23.3 & 0.047 & 0.054 & 0.220 \\
\hline SB6-3 SME Product (120\%) & SB6-3-2737 (B) & 09-0193 & 9.67 & 1.35 & $<0.010$ & 0.053 & $<0.010$ & $<0.100$ & 0.094 & 23.6 & 0.046 & 0.053 & 0.221 \\
\hline SB6-4 SME Product (150\%) & SB6-4-2701 (A) & 09-0191 & 9.11 & 1.32 & $<0.010$ & 0.047 & $<0.010$ & $<0.100$ & 0.082 & 24.1 & 0.047 & 0.051 & 0.217 \\
\hline SB6-4 SME Product $(150 \%)$ & SB6-4-2701 (B) & 09-0191 & 9.09 & 1.39 & $<0.010$ & 0.049 & $<0.010$ & $<0.100$ & 0.078 & 23.8 & 0.047 & 0.051 & 0.214 \\
\hline Sample Description & 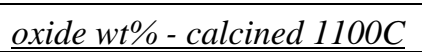 & & $\mathrm{Na} 2 \mathrm{O}$ & $\mathrm{NiU}$ & $\mathrm{P} 2 \mathrm{O} 5$ & $\mathrm{PbO}$ & $\underline{\mathrm{PdO}}$ & $\mathrm{RhO} 2$ & $\mathrm{SO} 4$ & $\mathrm{SiO} 2$ & $\mathrm{TiO} 2$ & $\mathrm{ZnO}$ & $\mathrm{ZrO} 2$ \\
\hline SB6-1 SME Product $(100 \%)$ & SB6-1-2684 (A) & $09-0190$ & 12.8 & 1.77 & $\overline{\text { LTD }}$ & $\overline{0.059}$ & $\overline{\text { LTD }}$ & $\overline{\text { LTD }}$ & $\overline{0.313}$ & 49.2 & $\overline{0.078}$ & $\overline{0.068}$ & $\overline{0.302}$ \\
\hline SB6-1 SME Product $(100 \%)$ & SB6-1-2684 (B) & 09-0190 & 12.8 & 1.78 & LTD & 0.057 & LTD & LTD & 0.320 & 49.1 & 0.078 & 0.073 & 0.302 \\
\hline SB6-2 SME Product (90\%) & SB6-2-2719 (A) & 09-0192 & 13.0 & 1.74 & LTD & 0.057 & LTD & LTD & 0.265 & 49.6 & 0.076 & 0.066 & 0.298 \\
\hline SB6-2 SME Product (90\%) & SB6-2-2719 (B) & & 12.9 & 1.76 & LTD & 0.056 & LTD & LTD & 0.261 & 49.8 & 0.077 & 0.068 & 0.300 \\
\hline SB6-3 SME Product (120\%) & SB6-3-2737 (A) & 09-0193 & 12.6 & 1.76 & LTD & 0.057 & LTD & LTD & 0.270 & 49.9 & 0.078 & 0.066 & 0.297 \\
\hline SB6-3 SME Product $(120 \%)$ & SB6-3-2737 (B) & 09-0193 & 13.1 & 1.71 & LTD & 0.057 & LTD & LTD & 0.281 & 50.4 & 0.077 & 0.066 & 0.298 \\
\hline SB6-4 SME Product $(150 \%)$ & SB6-4-2701 (A) & 09-0191 & 12.3 & 1.68 & LTD & 0.051 & LTD & LTD & 0.247 & 51.5 & 0.078 & 0.063 & 0.293 \\
\hline SB6-4 SME Product (150\%) & SB6-4-2701 (B) & 09-0191 & 12.3 & 1.77 & LTD & 0.053 & LTD & LTD & 0.235 & 51.0 & 0.078 & 0.064 & 0.289 \\
\hline
\end{tabular}

Units: $\mathrm{mg} / \mathrm{Kg}$

\begin{tabular}{|c|c|c|c|c|c|c|c|c|c|}
\hline Sample Description & Sample ID & Lab ID & $\mathrm{F}$ & $\mathrm{Cl}$ & $\mathrm{NO} 2$ & $\mathrm{NO} 3$ & $\mathrm{HCO} 2$ & $\mathrm{C} 2 \mathrm{O} 4$ & PO4 \\
\hline SB6-1 SME Product $(100 \%)$ & SB6-1-2684 (A) & 09-0190 & $<100$ & 365 & $<100$ & 23700 & 49700 & $<100$ & $<100$ \\
\hline SB6-1 SME Product $(100 \%)$ & SB6-1-2684 (B) & 09-0190 & $<100$ & 365 & $<100$ & 23600 & 49700 & $<100$ & $<100$ \\
\hline SB6-2 SME Product (90\%) & SB6-2-2719 (A) & 09-0192 & $<100$ & 333 & 995 & 21600 & 47700 & $<100$ & $<100$ \\
\hline SB6-2 SME Product (90\%) & SB6-2-2719 (B) & 09-0192 & $<100$ & 314 & 967 & 21400 & 47300 & $<100$ & $<100$ \\
\hline SB6-3 SME Product $(120 \%)$ & SB6-3-2737 (A) & 09-0193 & $<100$ & 328 & $<100$ & 28400 & 55800 & $<100$ & $<100$ \\
\hline SB6-3 SME Product (120\%) & SB6-3-2737 (B) & 09-0193 & $<100$ & 278 & $<100$ & 28300 & 54300 & $<100$ & $<100$ \\
\hline SB6-4 SME Product (150\%) & SB6-4-2701 (A) & 09-0191 & $<100$ & 363 & $<100$ & 33800 & 59700 & $<100$ & $<100$ \\
\hline SB6-4 SME Product $(150 \%)$ & SB6-4-2701 (B) & 09-0191 & $<100$ & 342 & $<100$ & 34200 & 61800 & $<100$ & $<100$ \\
\hline
\end{tabular}


SRNL-STI-2009-00413, REVISION 0

Weight \% Solids Calculations

\begin{tabular}{|c|c|c|c|c|c|c|c|c|}
\hline & & & Insoluble & $\mathrm{Wt} \%$ & Soluble & & & \\
\hline Sample Description & Sample & Lab ID & Total Solids & Solids & \begin{tabular}{l|l} 
& Calcined \\
\end{tabular} & Solids & Density & $\mathrm{pH}$ \\
\hline SB6-1 SME Product (100\%) & SB6-1-2684 (A) & $09-0190$ & $46.8 \%$ & $36.8 \%$ & $38.0 \%$ & $10.0 \%$ & 1.35 & 7.67 \\
\hline SB6-1 SME Product (100\%) & SB6-1-2684 (B) & $09-0190$ & $46.8 \%$ & $36.9 \%$ & $38.0 \%$ & $9.94 \%$ & & \\
\hline SB6-2 SME Product (90\%) & SB6-2-2719 (A) & 09-0192 & $47.1 \%$ & $37.9 \%$ & $38.5 \%$ & $9.18 \%$ & 1.37 & 7.38 \\
\hline SB6-2 SME Product (90\%) & SB6-2-2719 (B) & 09-0192 & $47.2 \%$ & $38.0 \%$ & $38.6 \%$ & $9.19 \%$ & & \\
\hline SB6-3 SME Product (120\%) & SB6-3-2737 (A) & 09-0193 & $46.5 \%$ & $36.1 \%$ & $37.0 \%$ & $10.4 \%$ & 1.36 & 5.85 \\
\hline SB6-3 SME Product (120\%) & SB6-3-2737 (B) & 09-0193 & $46.3 \%$ & $36.0 \%$ & $36.8 \%$ & $10.4 \%$ & & \\
\hline SB6-4 SME Product (150\%) & SB6-4-2701 (A) & 09-0191 & $47.3 \%$ & $37.7 \%$ & $36.9 \%$ & $9.59 \%$ & 1.35 & 4.97 \\
\hline SB6-4 SME Product (150\%) & SB6-4-2701 (B) & 09-0191 & $47.5 \%$ & $37.8 \%$ & $37.0 \%$ & $9.65 \%$ & & \\
\hline
\end{tabular}


SRNL-STI-2009-00413, REVISION 0

Table B4

PSAL SRAT Dewater Analytical Results

Process Science Analytical Laboratory

Customer: Dan Lambert

Date: 3/26/09, 3/31/2009, 4/13/09

Sample ID: Post SRAT Dewater: SB6-1-2681, SB6-2-2716, SB6-3-2734, SB6-4-2698, SB6-5-2752, SB6-6-2770, Post SME Dewater: SB6-1-2683, SB6-4-

2700, SB6-2-2718, SB6-3-2736, MWWT Samples: SB6-1-2680, SB6-2-2715, SB6-3-2733, SB6-4-2697, SB6-5-2750, SB6-6-2768, Post SRAT FAVC Sample: SB6-1-2680, SB6-2-2715, SB6-3-2733, SB6-4-2697, SB6-5-2751, SB6-6-2769, Post SME FAVC: SB6-1-2682, SB6-2-2717, SB6-3-2735, SB6-4-2699

Lab ID: 09-0169 - 09-0188, 09-0219 through 09-0224

\begin{tabular}{|c|c|c|c|c|c|c|c|c|c|}
\hline Units: mg/L & & & & & & & & & \\
\hline Sample ID & $\underline{\mathrm{Lab} I D}$ & $\underline{F}$ & $\underline{\mathrm{Cl}}$ & $\mathrm{NO} 2$ & $\mathrm{NO3}$ & $\mathrm{SO} 4$ & $\mathrm{HCO} 2$ & $\mathrm{C} 2 \mathrm{O} 4$ & $\mathrm{PO} 4$ \\
\hline \multicolumn{10}{|c|}{ SRAT Dewater Composite } \\
\hline SB6-1-2681 (A) & $09-0181$ & $<100$ & $<100$ & 275 & 5390 & $<100$ & 509 & $<100$ & $<100$ \\
\hline SB6-1-2681 (B) & 09-0181 & $<100$ & $<100$ & 301 & 5480 & $<100$ & 523 & $<100$ & $<100$ \\
\hline SB6-2-2716 (A) & $09-0185$ & $<100$ & $<100$ & 590 & 4260 & $<100$ & 395 & $<100$ & $<100$ \\
\hline SB6-2-2716 (B) & $09-0185$ & $<100$ & $<100$ & 576 & 4090 & $<100$ & 403 & $<100$ & $<100$ \\
\hline SB6-3-2734 (A) & $09-0187$ & $<100$ & $<100$ & 150 & 5940 & $<100$ & 1040 & $<100$ & $<100$ \\
\hline SB6-3-2734 (B) & $09-0187$ & $<100$ & $<100$ & 159 & 5940 & $<100$ & 1050 & $<100$ & $<100$ \\
\hline SB6-4-2698 (A) & 09-0183 & $<100$ & $<100$ & $<100$ & 1660 & $<100$ & 4620 & $<100$ & $<100$ \\
\hline SB6-4-2698 (B) & $09-0183$ & $<100$ & $<100$ & $<100$ & 1680 & $<100$ & 4680 & $<100$ & $<100$ \\
\hline SB6-5-2752 (A) & $09-0223$ & $<100$ & $<100$ & 608 & 7300 & $<100$ & 614 & $<1000$ & $<100$ \\
\hline SB6-5-2752 (B) & $09-0223$ & $<100$ & $<100$ & 615 & 7380 & $<100$ & 652 & $<1000$ & $<100$ \\
\hline SB6-6-2770 (A) & $09-0224$ & $<100$ & $<100$ & 289 & 10300 & $<100$ & 2200 & $<1000$ & $<100$ \\
\hline SB6-6-2770 (B) & $09-0224$ & $<100$ & $<100$ & 289 & 10200 & $<100$ & 2190 & $<1000$ & $<100$ \\
\hline \multicolumn{10}{|c|}{ SME Dewater Composite } \\
\hline SB6-1-2683 (A) & $09-0182$ & $<100$ & $<100$ & $<100$ & 152 & $<100$ & $<100$ & $<100$ & $<100$ \\
\hline SB6-1-2683 (B) & 09-0182 & $<100$ & $<100$ & $<100$ & 154 & $<100$ & $<100$ & $<100$ & $<100$ \\
\hline SB6-4-2700 (A) & 09-0184 & $<100$ & $<100$ & $<100$ & $<100$ & $<100$ & 3080 & $<100$ & $<100$ \\
\hline SB6-4-2700 (B) & 09-0184 & $<100$ & $<100$ & $<100$ & $<100$ & $<100$ & 3000 & $<100$ & $<100$ \\
\hline SB6-2-2718 (A) & $09-0186$ & $<100$ & $<100$ & $<100$ & 634 & $<100$ & $<100$ & $<100$ & $<100$ \\
\hline SB6-2-2718 (B) & $09-0186$ & $<100$ & $<100$ & $<100$ & 625 & $<100$ & $<100$ & $<100$ & $<100$ \\
\hline SB6-3-2736 (A) & 09-0188 & $<100$ & $<100$ & $<100$ & $<100$ & $<100$ & 506 & $<100$ & $<100$ \\
\hline SB6-3-2736 (B) & 09-0188 & $<100$ & $<100$ & $<100$ & $<100$ & $<100$ & 499 & $<100$ & $<100$ \\
\hline
\end{tabular}


SRNL-STI-2009-00413, REVISION 0

\begin{tabular}{|c|c|c|c|c|c|c|c|c|c|}
\hline MWWT Samples & & & & & & & & & \\
\hline \multicolumn{10}{|l|}{ Units: $\mathrm{mg} / \mathrm{L}$} \\
\hline Sample ID & $\underline{\mathrm{Lab} I D}$ & $\underline{F}$ & $\underline{\mathrm{Cl}}$ & $\mathrm{NO} 2$ & $\mathrm{NO} 3$ & $\underline{\mathrm{SO} 4}$ & $\underline{\mathrm{HCO} 2}$ & $\underline{\mathrm{C} 2 \mathrm{O} 4}$ & $\underline{\mathrm{PO} 4}$ \\
\hline SB6-1-2679 (A) & 09-0171 & $<100$ & $<100$ & $<100$ & 232 & $<100$ & $<100$ & $<100$ & \\
\hline SB6-1-2679 (B) & 09-0171 & $<100$ & $<100$ & $<100$ & 219 & $<100$ & $<100$ & $<100$ & \\
\hline SB6-2-2714 (A) & 09-0177 & $<100$ & $<100$ & $<100$ & 461 & $<100$ & $<100$ & NM & $<100$ \\
\hline SB6-2-2714 (B) & 09-0177 & $<100$ & $<100$ & $<100$ & 373 & $<100$ & $<100$ & $\mathrm{NM}$ & $<100$ \\
\hline SB6-4-2696 (A) & 09-0174 & $<100$ & $<100$ & $<100$ & $<100$ & $<100$ & 3000 & $\mathrm{NM}$ & $<100$ \\
\hline SB6-4-2696 (B) & 09-0174 & $<100$ & $<100$ & $<100$ & $<100$ & $<100$ & 3080 & NM & $<100$ \\
\hline SB6-3-2732 (A) & 09-0180 & $<100$ & $<100$ & $<100$ & $<100$ & $<100$ & 509 & $\mathrm{NM}$ & $<100$ \\
\hline SB6-3-2732 (B) & 09-0180 & $<100$ & $<100$ & $<100$ & $<100$ & $<100$ & 467 & NM & $<100$ \\
\hline SB6-5-2750 (A) & 09-0219 & $<100$ & $<100$ & $<100$ & 232 & $<100$ & $<100$ & $<1000$ & $<100$ \\
\hline SB6-5-2750 (B) & 09-0219 & $<100$ & $<100$ & $<100$ & 243 & $<100$ & $<100$ & $<1000$ & $<100$ \\
\hline SB6-6-2768 (A) & $09-0221$ & $<100$ & $<100$ & $<100$ & 181 & $<100$ & 298 & $<1000$ & $<100$ \\
\hline SB6-6-2768 (B) & 09-0221 & $<100$ & $<100$ & $<100$ & 180 & $<100$ & 251 & $<1000$ & $<100$ \\
\hline \multicolumn{10}{|c|}{ Post SRAT FAVC Sample } \\
\hline SB6-1-2680 (A) & 09-0170 & $<100$ & $<100$ & $<100$ & 686000 & $<100$ & 308 & NM & $<100$ \\
\hline SB6-1-2680 (B) & 09-0170 & $<100$ & $<100$ & $<100$ & 685000 & $<100$ & 269 & NM & $<100$ \\
\hline SB6-2-2715 (A) & 09-0176 & $<100$ & $<100$ & $<100$ & 657000 & $<100$ & 230 & NM & $<100$ \\
\hline SB6-2-2715 (B) & 09-0176 & $<100$ & $<100$ & $<100$ & 669000 & $<100$ & 229 & NM & $<100$ \\
\hline SB6-3-2733 (A) & 09-0179 & $<100$ & $<100$ & $<100$ & 633000 & $<100$ & 240 & $\mathrm{NM}$ & $<100$ \\
\hline SB6-3-2733 (B) & 09-0179 & $<100$ & $<100$ & $<100$ & 629000 & $<100$ & 220 & $\mathrm{NM}$ & $<100$ \\
\hline SB6-4-2697 (A) & 09-0173 & $<100$ & $<100$ & $<100$ & 542000 & $<100$ & 772 & $\mathrm{NM}$ & $<100$ \\
\hline SB6-4-2697 (B) & 09-0173 & $<100$ & $<100$ & $<100$ & 528000 & $<100$ & 779 & NM & $<100$ \\
\hline SB6-5-2751 (A) & 09-0220 & $<100$ & $<100$ & $<100$ & 536000 & $<100$ & 157 & $<1000$ & $<100$ \\
\hline SB6-5-2751 (B) & 09-0220 & $<100$ & $<100$ & $<100$ & 536000 & $<100$ & 181 & $<1000$ & $<100$ \\
\hline SB6-6-2769 (A) & $09-0222$ & $<100$ & $<100$ & $<100$ & 486000 & $<100$ & 272 & $<1000$ & $<100$ \\
\hline SB6-6-2769 (B) & 09-0222 & $<100$ & $<100$ & $<100$ & 488000 & $<100$ & 242 & $<1000$ & $<100$ \\
\hline
\end{tabular}


SRNL-STI-2009-00413, REVISION 0

\begin{tabular}{|c|c|c|}
\hline Units: $\mathrm{g} / \mathrm{mL}$ & & \\
\hline Sample ID & Lab ID & Density \\
\hline \multicolumn{3}{|c|}{ SRAT Dewater Composite } \\
\hline SB6-1-2681 & 09-0181 & 1.02 \\
\hline SB6-2-2716 & 09-0185 & 1.02 \\
\hline SB6-3-2734 & $09-0187$ & 1.01 \\
\hline SB6-4-2698 & $09-0183$ & 1.01 \\
\hline SB6-5-2752 & $09-0223$ & 1.00 \\
\hline SB6-6-2770 & $09-0224$ & 1.00 \\
\hline \multicolumn{3}{|c|}{ SME Dewater Composite } \\
\hline SB6-1-2683 & $09-0182$ & 1.01 \\
\hline SB6-2-2718 & $09-0186$ & 1.01 \\
\hline SB6-3-2736 & 09-0188 & 1.01 \\
\hline SB6-4-2700 & 09-0184 & 1.01 \\
\hline \multicolumn{3}{|c|}{ MWWT Samples } \\
\hline SB6-1-2679 & $09-0171$ & 1.09 \\
\hline SB6-2-2714 & $09-0177$ & 1.01 \\
\hline SB6-3-2732 & $09-0180$ & 1.01 \\
\hline SB6-4-2696 & $09-0174$ & 1.01 \\
\hline SB6-5-2750 & 09-0219 & 0.998 \\
\hline SB6-6-2768 & 09-0221 & 1.20 \\
\hline \multicolumn{3}{|c|}{ Post SRAT FAVC Sample } \\
\hline SB6-1-2680 & 09-0170 & 1.24 \\
\hline SB6-2-2715 & $09-0176$ & 1.23 \\
\hline SB6-3-2733 & 09-0179 & 1.22 \\
\hline SB6-4-2697 & 09-0173 & 1.19 \\
\hline SB6-5-2751 & $09-0220$ & 0.998 \\
\hline SB6-6-2769 & 09-0222 & 1.19 \\
\hline
\end{tabular}


SRNL-STI-2009-00413, REVISION 0

\section{Table B5}

PSAL SRAT Intermediate Slurry Sample Analytical Results

Process Science Analytical Laboratory

Customer: Dan Lambert

Date: $4 / 6 / 09,4 / 14 / 09$

Sample ID: SB6-1-2672, SB6-1-2676, SB6-4-2689, SB6-4-2693, SB6-2-2706, SB6-2-2710, SB6-3-2724, SB6-3-2728 (slurry), SB6-5-2743, SB6-5-2747,

SB6-6-2760, and SB6-6-2765

Lab ID: 09-0157 - 09-0164, 09-0225 - 09-0228

\section{Units: $\mathrm{mg} / \mathrm{Kg}$}

Sample ID

Lab ID

$\mathrm{Cl} 1 \mathrm{NO} 2$

Post Formic Slurry Sample (corrected for caustic dilution)

\begin{tabular}{|l|c|c|c|c|c|c|c|c|c|c|}
\hline SB6-1-2672 (A) & $09-0157$ & $<108$ & $<108$ & 6,590 & 19,742 & $<108$ & 43,800 & $<108$ & $<108$
\end{tabular}

SB6-1-2672 (B)

SB6-2-2706 (A)

SB6-2-2706 (B)

SB6-3-2724 (A)

SB6-3-2724 (B)

SB6-4-2689 (A)

SB6-4-2689 (B)

30 min prior to SRAT Complete

SB6-1-2676 (A)

SB6-1-2676 (B)

SB6-2-2710 (A)

SB6-2-2710 (B)

SB6-3-2728 (A)

SB6-3-2728 (B)

SB6-4-2693 (A)

SB6-4-2693 (B)

SB6-5-2747 (A)

SB6-5-2747 (B)

SB6-6-2765 (A)

SB6-6-2765 (B)

\begin{tabular}{|c|c|c|c|c|c|c|c|c|}
\hline $09-0157$ & $<108$ & $<108$ & 6,590 & 19,742 & $<108$ & 43,800 & $<108$ & $<108$ \\
\hline $09-0157$ & $<108$ & $<108$ & 6,690 & 19,958 & $<108$ & 43,584 & $<108$ & $<108$ \\
\hline $09-0161$ & $<108$ & 252.3 & 8,853 & 17,793 & 117 & 41,517 & $<108$ & $<108$ \\
\hline $09-0161$ & $<108$ & 251.3 & 8,875 & 17,577 & 112 & 41,517 & $<108$ & $<108$ \\
\hline $09-0163$ & $<107$ & 138.2 & 4,522 & 24,538 & 189 & 50,362 & $<107$ & $<107$ \\
\hline $09-0163$ & $<107$ & 133.9 & 4,522 & 24,967 & 193 & 51,219 & $<107$ & $<107$ \\
\hline $09-0159$ & $<108$ & 152.4 & $<108$ & 32,759 & 227 & 69,086 & $<108$ & $<108$ \\
\hline $09-0159$ & $<108$ & 150.3 & $<108$ & 33,516 & 280 & 72,870 & $<108$ & $<108$ \\
\hline & & & & & & & $<100$ \\
\hline $09-0158$ & $<100$ & 379 & 258 & 26000 & $<100$ & 50100 & $<100$ & $<100$ \\
\hline $09-0158$ & $<100$ & 387 & 259 & 25500 & $<100$ & 49600 & $<100$ & $<100$ \\
\hline $09-0162$ & $<100$ & 337 & 1980 & 23500 & $<100$ & 48200 & $<100$ & $<100$ \\
\hline $09-0162$ & $<100$ & 337 & 1960 & 23600 & $<100$ & 49100 & $<100$ & $<100$ \\
\hline $09-0164$ & $<100$ & 314 & $<100$ & 30200 & $<100$ & 55500 & $<100$ & $<100$ \\
\hline $09-0164$ & $<100$ & 302 & $<100$ & 30400 & $<100$ & 55700 & $<100$ & $<100$ \\
\hline $09-0160$ & $<100$ & 347 & $<100$ & 41500 & 440 & 73700 & $<100$ & $<100$ \\
\hline $09-0160$ & $<100$ & 312 & $<100$ & 37000 & 466 & 70200 & $<100$ & $<100$ \\
\hline $09-0226$ & $<100$ & 362 & 594 & 24500 & $<100$ & 53300 & $<100$ & $<100$ \\
\hline $09-0226$ & $<100$ & 357 & 583 & 24700 & $<100$ & 53500 & $<100$ & $<100$ \\
\hline $09-0228$ & $<100$ & 332 & $<100$ & 29600 & $<100$ & 57200 & $<100$ & $<100$ \\
\hline $09-0228$ & $<100$ & 333 & $<100$ & 31900 & $<100$ & 57900 & $<100$ & $<100$ \\
\hline
\end{tabular}


SRNL-STI-2009-00413, REVISION 0

\section{Table B6}

\section{PSAL SRAT Intermediate Centrifuged Sample Analytical Results}

Process Science Analytical Laboratory

Customer: Dan Lambert

Date: 4/2/09, 4/8/09

Sample ID: Mid Formic: SB6-1-2670, SB6-2-2704, SB6-3-2722, SB6-4-2687, SB6-5-2741, SB6-6-2758 (centrifuged supernate)

Sample ID: Post Formic: SB6-1-2671, SB6-2-2705, SB6-3-2723, SB6-4-2688, SB6-5-2742, SB6-6-2759 (centrifuged supernate)

Sample ID: Post Dewater: SB6-1-2673, SB6-2-2707, SB6-3-2725, SB6-4-2690. SB6-5-2744, SB6-6-2761 (centrifuged supernate)

Lab ID: 09-0229-0234

elemental $\mathrm{mg} / \mathrm{L}$

\begin{tabular}{|c|c|c|c|c|c|c|c|c|c|c|c|c|c|}
\hline$\underline{\text { Sample ID }}$ & $\underline{\mathrm{Lab}}$ ID & $\underline{\mathrm{Al}}$ & $\underline{\mathrm{Ba}}$ & $\underline{\mathrm{Ca}}$ & $\underline{\mathrm{Cd}}$ & $\underline{\mathrm{Ce}}$ & $\underline{\mathrm{Cr}}$ & $\underline{\mathrm{Cu}}$ & $\underline{\mathrm{Fe}}$ & $\underline{\mathrm{K}}$ & $\underline{\mathrm{Mn}}$ & $\underline{\mathrm{Na}}$ & $\underline{\mathrm{Ni}}$ \\
\hline \multicolumn{14}{|l|}{ Mid Formic } \\
\hline SB6-1-2670 & 09-0145 & 1.92 & 0.593 & 1710 & $<0.100$ & $<10.0$ & $<0.100$ & 0.152 & 1.44 & 293 & 1150 & 24900 & 56.9 \\
\hline SB6-2-2704 & $09-0151$ & 0.483 & 0.413 & 1300 & $<0.100$ & $<10.0$ & $<0.100$ & 0.133 & $<0.100$ & 446 & 1060 & 25300 & 51.9 \\
\hline SB6-3-2722 & 09-0154 & 1.62 & 0.335 & 629 & $<0.100$ & $<10.0$ & $<0.100$ & $<0.100$ & 1.16 & 270 & 503 & 25200 & 16.5 \\
\hline SB6-4-2687 & 09-0148 & 1.11 & 0.743 & 795 & $<0.100$ & $<10.0$ & $<0.100$ & $<0.100$ & $<0.100$ & 275 & 1150 & 25100 & 48.1 \\
\hline SB6-5-2741 & 09-0229 & 0.589 & 3.41 & 2020 & $<0.100$ & $<10.0$ & $<0.100$ & 0.557 & $<0.100$ & 293 & 2120 & 27800 & 141.0 \\
\hline SB6-6-2758 & 09-0232 & 0.605 & 0.491 & 675 & $<0.100$ & $<10.0$ & $<0.100$ & $<0.100$ & $<0.100$ & 277 & 967 & 27300 & 12.2 \\
\hline \multicolumn{14}{|l|}{ Post Formic } \\
\hline SB6-1-2671 & $09-0146$ & 40.0 & 2.01 & 2670 & $<0.100$ & $<10.0$ & 2.71 & 13.8 & 1.94 & 344 & 6060 & 24700 & 1460 \\
\hline SB6-2-2705 & 09-0152 & 49.9 & 3.28 & 2640 & $<0.100$ & $<10.0$ & 2.54 & 10.0 & 1.26 & 656 & 4910 & 25200 & 1250 \\
\hline SB6-3-2723 & 09-0155 & 260 & 2.34 & 2630 & $<0.100$ & $<10.0$ & 14.8 & 28.4 & 12.09 & 289 & 7560 & 24200 & 2360 \\
\hline SB6-4-2688 & 09-0149 & 861 & 1.93 & 2590 & $<0.100$ & $<10.0$ & 39.2 & 59.8 & 63.0 & 304 & 9060 & 23500 & 3450 \\
\hline SB6-5-2742 & 09-0230 & 41.9 & 6.11 & 3300 & $<0.100$ & $<10.0$ & 3.24 & 15.0 & 1.62 & 302 & 6820 & 9150 & 1430 \\
\hline SB6-6-2759 & 09-0233 & 149 & 4.87 & 3110 & $<0.100$ & $<10.0$ & 11.5 & 27.9 & 7.76 & 301 & 8990 & 26900 & 2270 \\
\hline \multicolumn{14}{|l|}{ Post Dewater } \\
\hline SB6-1-2673 & 09-0147 & 0.548 & 4.51 & 3490 & $<0.100$ & $<10.0$ & $<0.100$ & 0.225 & $<0.100$ & 598 & 5350 & 35900 & 23.3 \\
\hline SB6-2-2707 & 09-0153 & 0.581 & 4.63 & 3550 & $<0.100$ & $<10.0$ & $<0.100$ & $<0.100$ & $<0.100$ & 485 & 3270 & 37500 & 11.1 \\
\hline SB6-3-2725 & 09-0156 & 1.30 & 5.36 & 3330 & $<0.100$ & $<10.0$ & 0.301 & 5.08 & $<0.100$ & 430 & 11000 & 33200 & 440 \\
\hline SB6-4-2690 & 09-0150 & 276 & 4.66 & 3340 & $<0.100$ & $<10.0$ & 24.7 & 77.0 & 2160 & 428 & 7290 & 30800 & 2460 \\
\hline SB6-5-2744 & 09-0231 & 1.150 & 4.31 & 3490 & $<0.100$ & $<10.0$ & $<0.100$ & 0.191 & 0.365 & 419 & 6200 & 34300 & 41.3 \\
\hline SB6-6-2761 & 09-0234 & 3.91 & 7.51 & 3520 & $<0.100$ & $<10.0$ & 0.531 & 8.72 & 0.372 & 383 & 10700 & 33100 & 843 \\
\hline
\end{tabular}


SRNL-STI-2009-00413, REVISION 0

elemental mg/L

\begin{tabular}{|l|l|l|l|l|l|l|l|l|l|l|}
\hline$\underline{\text { Sample ID }}$ & $\underline{\text { Lab ID }}$ & $\underline{\mathrm{P}}$ & $\underline{\mathrm{Pb}}$ & $\underline{\mathrm{Pd}}$ & $\underline{\mathrm{Rh}}$ & $\underline{\mathrm{Ru}}$ & $\underline{\mathrm{Si}}$ & $\underline{\mathrm{Ti}}$ & $\underline{\mathrm{Zn}}$ & $\underline{\mathrm{Zr}}$ \\
\hline Mid Formic & & & & & & & & & & \\
\hline SB6-1-2670 & $09-0145$ & $<10.0$ & $<0.100$ & $<1.00$ & 8.88 & 3.01 & 21.6 & $<0.100$ & $<0.100$ & $<1.00$ \\
\hline SB6-2-2704 & $09-0151$ & $<10.0$ & $<0.100$ & $<1.00$ & 9.61 & 2.32 & 23.6 & $<0.100$ & $<0.100$ & $<1.00$ \\
\hline SB6-3-2722 & $09-0154$ & $<10.0$ & $<0.100$ & $<1.00$ & 6.36 & $<1.00$ & 31.0 & $<0.100$ & $<0.100$ & $<1.00$ \\
\hline SB6-4-2687 & $09-0148$ & $<10.0$ & $<0.100$ & $<1.00$ & 9.50 & 1.90 & 48.1 & $<0.100$ & $<0.100$ & $<1.00$ \\
\hline SB6-5-2741 & $09-0229$ & $<10.0$ & $<0.100$ & $<1.00$ & 6.94 & $\mathrm{NM}$ & 20.1 & $<0.100$ & $<0.100$ & $<1.00$ \\
\hline SB6-6-2758 & $09-0232$ & $<10.0$ & $<0.100$ & $<1.00$ & 6.70 & $\mathrm{NM}$ & 17.0 & $<0.100$ & $<0.100$ & $<1.00$ \\
\hline Post Formic & & & & & & & & & & \\
\hline SB6-1-2671 & $09-0146$ & $<10.0$ & 1.91 & $<1.00$ & 12.0 & 32.0 & 22.6 & $<0.100$ & 12.1 & $<1.00$ \\
\hline SB6-2-2705 & $09-0152$ & $<10.0$ & 0.607 & $<1.00$ & 11.7 & 22.4 & 27.8 & $<0.100$ & 9.10 & $<1.00$ \\
\hline SB6-3-2723 & $09-0155$ & $<10.0$ & 5.25 & $<1.00$ & 18.5 & 33.8 & 27.1 & $<0.100$ & 24.9 & $<1.00$ \\
\hline SB6-4-2688 & $09-0149$ & $<10.0$ & 0.432 & $<1.00$ & 0.632 & $<1.00$ & 62.1 & $<0.100$ & 4.95 & $<1.00$ \\
\hline SB6-5-2742 & $09-0230$ & $<10.0$ & 1.93 & $<1.00$ & 8.65 & $\mathrm{NM}$ & 22.0 & $<0.100$ & 12.0 & $<1.00$ \\
\hline SB6-6-2759 & $09-0233$ & $<10.0$ & 5.47 & $<1.00$ & 15.7 & $\mathrm{NM}$ & 22.9 & $<0.100$ & 22.6 & $<1.00$ \\
\hline Post Dewater & & & & & & & & & & \\
\hline SB6-1-2673 & $09-0147$ & $<10.0$ & $<0.100$ & $<1.00$ & 2.80 & $<1.00$ & 32.4 & $<0.100$ & $<0.100$ & $<1.00$ \\
\hline SB6-2-2707 & $09-0153$ & $<10.0$ & $<0.100$ & $<1.00$ & 6.39 & $<1.00$ & 22.5 & $<0.100$ & $<0.100$ & $<1.00$ \\
\hline SB6-3-2725 & $09-0156$ & $<10.0$ & 0.432 & $<1.00$ & 0.632 & $<1.00$ & 62.1 & $<0.100$ & 4.95 & $<1.00$ \\
\hline SB6-4-2690 & $09-0150$ & $<10.0$ & 28.4 & $<1.00$ & 3.35 & 38.5 & 111 & $<0.100$ & 38.4 & $<1.00$ \\
\hline SB6-5-2744 & $09-0231$ & $<10.0$ & $<0.100$ & $<1.00$ & 7.07 & $\mathrm{NM}$ & 32.9 & $<0.100$ & $<0.100$ & $<1.00$ \\
\hline SB6-6-2761 & $09-0234$ & $<10.0$ & 1.50 & $<1.00$ & 1.06 & $\mathrm{NM}$ & 30.0 & $<0.100$ & 8.06 & $<1.00$ \\
\hline
\end{tabular}

NM=Not Measured 
Density, $\mathbf{g} / \mathbf{m L}$

\begin{tabular}{|c|c|c|}
\hline Sample ID & Lab ID & $\begin{array}{c}\text { Density, } \\
\mathrm{g} / \mathrm{mL}\end{array}$ \\
\hline Mid Formic & & \\
\hline SB6-1-2670 & $09-0145$ & 1.05 \\
\hline SB6-2-2704 & $09-0151$ & 1.05 \\
\hline SB6-3-2722 & $09-0154$ & 1.05 \\
\hline SB6-4-2687 & $09-0148$ & 1.05 \\
\hline SB6-5-2741 & $09-0229$ & 1.06 \\
\hline SB6-6-2758 & $09-0232$ & 1.05 \\
\hline Post Formic & & \\
\hline SB6-1-2671 & $09-0146$ & 1.07 \\
\hline SB6-2-2705 & $09-0152$ & 1.06 \\
\hline SB6-3-2723 & $09-0155$ & 1.07 \\
\hline SB6-4-2688 & $09-0149$ & 1.08 \\
\hline SB6-5-2742 & $09-0230$ & 1.07 \\
\hline SB6-6-2759 & $09-0233$ & 1.08 \\
\hline Post Dewater & & \\
\hline SB6-1-2673 & $09-0147$ & 1.08 \\
\hline SB6-2-2707 & $09-0153$ & 1.08 \\
\hline SB6-3-2725 & $09-0156$ & 1.09 \\
\hline SB6-4-2690 & $09-0150$ & 1.09 \\
\hline SB6-5-2744 & $09-0231$ & 1.08 \\
\hline SB6-6-2761 & $09-0234$ & 1.09 \\
\hline
\end{tabular}


SRNL-STI-2009-00413, REVISION 0

Table B7

AD Mercury Analytical Results, wt \% total solids

\begin{tabular}{|c|c|c|c|c|c|c|c|c|c|c|}
\hline Sample Id & User SampleID & Sample Type & LIMS Method & Component & Sample Mass & Result & $1 \mathrm{SIGMA} \%$ UNC & Units & $\mathrm{Rv}$ & Corrected Result \\
\hline 300258542 & 09 SB6 12674 & $6 \mathrm{hr}$ & CVAA HG (B143) & $\mathrm{Hg}$ & 2.52 & 61.2 & 20 & $\mathrm{mg} / \mathrm{L}$ & 1 & 0.971 \\
\hline 300258543 & 09 SB6 1_2675 & Product & CVAA HG (B143) & $\mathrm{Hg}$ & 1.671 & 35.7 & 20 & $\mathrm{mg} / \mathrm{L}$ & 1 & 0.855 \\
\hline 300258546 & 09_SB6_2_2708 & $6 \mathrm{hr}$ & CVAA HG (B143) & $\mathrm{Hg}$ & 1.5693 & 28.6 & 20 & $\mathrm{mg} / \mathrm{L}$ & 1 & 0.729 \\
\hline 300258547 & 09 SB6 2 2 2709 & Product & CVAA HG (B143) & $\mathrm{Hg}$ & 2.24 & 29.4 & 20 & $\mathrm{mg} / \mathrm{L}$ & 1 & 0.525 \\
\hline 300258548 & 09 SB6 $3 \quad 2726$ & $6 \mathrm{hr}$ & CVAA HG (B143) & $\mathrm{Hg}$ & 2.0539 & 71.2 & 20 & $\mathrm{mg} / \mathrm{L}$ & 1 & 1.387 \\
\hline 300258549 & 09 SB6 3 2727 & Product & CVAA HG (B143) & $\mathrm{Hg}$ & 1.0827 & 2.55 & 20 & $\mathrm{mg} / \mathrm{L}$ & 1 & 0.094 \\
\hline 300258544 & 09 SB6 4 42691 & $6 \mathrm{hr}$ & CVAA HG (B143) & $\mathrm{Hg}$ & 1.23 & 4.18 & 20 & $\mathrm{mg} / \mathrm{L}$ & 1 & 0.136 \\
\hline 300258545 & 09 SB6 42692 & Product & CVAA HG (B143) & $\mathrm{Hg}$ & 1.18 & 1.89 & 20 & $\mathrm{mg} / \mathrm{L}$ & 1 & 0.064 \\
\hline 300258550 & $09 \_$SB6_5_2745 & $6 \mathrm{hr}$ & CVAA HG (B143) & $\mathrm{Hg}$ & 1.2103 & 22.2 & 20 & $\mathrm{mg} / \mathrm{L}$ & 1 & 0.734 \\
\hline 300258551 & 09 SB6 5_2746 & Product & CVAA HG (B143) & $\mathrm{Hg}$ & 1.11 & 19.8 & 20 & $\mathrm{mg} / \mathrm{L}$ & 1 & 0.714 \\
\hline 300258552 & 09 SB6 6 6_2763 & $6 \mathrm{hr}$ & CVAA HG (B143) & $\mathrm{Hg}$ & 1.0393 & 9.02 & 20 & $\mathrm{mg} / \mathrm{L}$ & 1 & 0.347 \\
\hline 300258553 & 09 SB_6_6_2764 & Product & CVAA HG (B143) & $\mathrm{Hg}$ & 1.0342 & 13.4 & 20 & $\mathrm{mg} / \mathrm{L}$ & 1 & 0.518 \\
\hline
\end{tabular}


SRNL-STI-2009-00413, REVISION 0

Table B8

AD Ammonium and Carbon Analytical Results on SRAT and SME product

\begin{tabular}{|c|c|c|c|c|c|c|c|}
\hline Product? & Sample Id & User SampleID & LIMS Method & Component & Result & 1 SIGMA \% UNC & Units \\
\hline SRAT Product & 300258554 & 09 SB6_1_2678 & TIC/TOC (B154) & Inorganic Carbon & 24.2 & 10 & ug $\mathrm{C} / \mathrm{mL}$ \\
\hline SRAT Product & 300258558 & 09 SB6 2 2 2713 & TIC/TOC (B154) & Inorganic Carbon & 29.6 & 10 & ug C/mL \\
\hline SRAT Product & 300258560 & 09_SB6_3_2731 & TIC/TOC (B154) & Inorganic Carbon & 8.68 & 10 & ug C/mL \\
\hline SRAT Product & 300258556 & 09_SB6_4_2695 & TIC/TOC (B154) & Inorganic Carbon & 35.8 & 10 & ug $\mathrm{C} / \mathrm{mL}$ \\
\hline SRAT Product & 300258562 & 09 SB6 5 5_2749 & TIC/TOC (B154) & Inorganic Carbon & 20.4 & 10 & $\operatorname{ug~} \mathrm{C} / \mathrm{mL}$ \\
\hline SRAT Product & 300258554 & 09_SB6_1_2678 & TIC/TOC (B154) & Organic Carbon & 16,600 & 10 & $\mathrm{ug} \mathrm{C} / \mathrm{mL}$ \\
\hline SRAT Product & 300258558 & 09 SB6 2 2713 & TIC/TOC (B154) & Organic Carbon & 15,100 & 10 & ug $\mathrm{C} / \mathrm{mL}$ \\
\hline SRAT Product & 300258560 & 09 SB6 3 3_2731 & TIC/TOC (B154) & Organic Carbon & 17,200 & 10 & $\mathrm{ug} \mathrm{C} / \mathrm{mL}$ \\
\hline SRAT Product & 300258556 & 09_SB6_4_2695 & TIC/TOC (B154) & Organic Carbon & 15,000 & 10 & $\operatorname{ug~} \mathrm{C} / \mathrm{mL}$ \\
\hline SRAT Product & 300258562 & 09_SB6_5_2749 & TIC/TOC (B154) & Organic Carbon & 15,300 & 10 & $\mathrm{ug} \mathrm{C} / \mathrm{mL}$ \\
\hline SRAT Product & 300258554 & 09_SB6_1_2678 & TIC/TOC (B154) & Total Carbon & 16,600 & 10 & $\operatorname{ug~} \mathrm{C} / \mathrm{mL}$ \\
\hline SRAT Product & 300258558 & 09_SB6_2_2713 & TIC/TOC (B154) & Total Carbon & 15,100 & 10 & ug C/mL \\
\hline SRAT Product & 300258560 & 09 SB6 3 3_2731 & TIC/TOC (B154) & Total Carbon & 17,200 & 10 & ug C/mL \\
\hline SRAT Product & 300258556 & 09 SB6_4_2695 & TIC/TOC (B154) & Total Carbon & 15,000 & 10 & ug C/mL \\
\hline SRAT Product & 300258562 & 09 SB6 5 2749 & TIC/TOC (B154) & Total Carbon & 15,300 & 10 & ug $\mathrm{C} / \mathrm{mL}$ \\
\hline SME Product & 300258564 & 09 SB6 $6 \quad 2767$ & TIC/TOC (B154) & Inorganic Carbon & 16.4 & 10 & ug $\mathrm{C} / \mathrm{mL}$ \\
\hline SME Product & 300258564 & 09 SB6_6_2767 & TIC/TOC (B154) & Organic Carbon & 17,500 & 10 & ug $\mathrm{C} / \mathrm{mL}$ \\
\hline SME Product & 300258564 & 09 SB6_6_2767 & TIC/TOC (B154) & Total Carbon & 17,500 & 10 & ug C/mL \\
\hline SME Product & 300258555 & 09_SB6_1_2685 & TIC/TOC (B154) & Inorganic Carbon & 21.2 & 10 & ug C/mL \\
\hline SME Product & 300258559 & 09_SB6_2_2720 & TIC/TOC (B154) & Inorganic Carbon & 25.7 & 10 & ug C/mL \\
\hline SME Product & 300258561 & 09 SB_S6_3_2738 & TIC/TOC (B154) & Inorganic Carbon & 20.9 & 10 & ug $\mathrm{C} / \mathrm{mL}$ \\
\hline SME Product & 300258557 & 09 SB6 4 42702 & TIC/TOC (B154) & Inorganic Carbon & 78.4 & 10 & ug C/mL \\
\hline SME Product & 300258555 & 09 SB6_1_2685 & TIC/TOC (B154) & Organic Carbon & 20,600 & 10 & ug $\mathrm{C} / \mathrm{mL}$ \\
\hline SME Product & 300258559 & 09 SB6 2 2 2720 & TIC/TOC (B154) & Organic Carbon & 19,700 & 10 & ug $\mathrm{C} / \mathrm{mL}$ \\
\hline SME Product & 300258561 & 09 SB6_3_2738 & TIC/TOC (B154) & Organic Carbon & 19,000 & 10 & ug $\mathrm{C} / \mathrm{mL}$ \\
\hline SME Product & 300258557 & 09 SB6 4 4_2702 & TIC/TOC (B154) & Organic Carbon & 16,800 & 10 & ug C/mL \\
\hline SME Product & 300258555 & 09_SB6_1_2685 & TIC/TOC (B154) & Total Carbon & 20,600 & 10 & ug $\mathrm{C} / \mathrm{mL}$ \\
\hline SME Product & 300258559 & 09 SB6_2_2720 & TIC/TOC (B154) & Total Carbon & 19,700 & 10 & $\mathrm{ug} \mathrm{C} / \mathrm{mL}$ \\
\hline SME Product & 300258561 & 09 S_SB6_3_2738 & TIC/TOC (B154) & Total Carbon & 19,000 & 10 & ug C/mL \\
\hline SME Product & 300258557 & 09 SB6 4 4 2 2702 & TIC/TOC (B154) & Total Carbon & 16,900 & 10 & ug $\mathrm{C} / \mathrm{mL}$ \\
\hline SRAT Product & 300258554 & 09 SB6 12678 & IC Cations (B134) & Ammonium Ion & $<25$ & 10 & $\mathrm{ug} / \mathrm{mL}$ \\
\hline SRAT Product & 300258558 & 09 SB6 2_2713 & IC Cations (B134) & Ammonium Ion & $<25$ & 10 & $\mathrm{ug} / \mathrm{mL}$ \\
\hline
\end{tabular}


SRNL-STI-2009-00413, REVISION 0

\begin{tabular}{|c|c|c|c|c|c|c|c|}
\hline Product? & Sample Id & User SampleID & LIMS Method & Component & Result & 1 SIGMA \% UNC & Units \\
\hline SRAT Product & 300258560 & 09 SB6 3 32731 & IC Cations (B134) & Ammonium Ion & $<25$ & 10 & $\mathrm{ug} / \mathrm{mL}$ \\
\hline SRAT Product & 300258556 & 09_SB6_4_2695 & IC Cations (B134) & Ammonium Ion & $<25^{\dagger \dagger}$ & 10 & $\mathrm{ug} / \mathrm{mL}$ \\
\hline SRAT Product & 300258562 & 09_SB6_5_2749 & IC Cations (B134) & Ammonium Ion & $<25$ & 10 & $\mathrm{ug} / \mathrm{mL}$ \\
\hline SME Product & 300258555 & 09_SB6_1_2685 & IC Cations (B134) & Ammonium Ion & $<25$ & 10 & $\mathrm{ug} / \mathrm{mL}$ \\
\hline SME Product & 300258559 & 09_SB6_2_2720 & IC Cations (B134) & Ammonium Ion & $<25$ & 10 & $\mathrm{ug} / \mathrm{mL}$ \\
\hline SME Product & 300258561 & 09 SB6_3_2738 & IC Cations (B134) & Ammonium Ion & $<25$ & 10 & $\mathrm{ug} / \mathrm{mL}$ \\
\hline SME Product & 300258557 & 09_SB6_4_2702 & IC Cations (B134) & Ammonium Ion & 27 & 10 & $\mathrm{ug} / \mathrm{mL}$ \\
\hline
\end{tabular}

\footnotetext{
${ }^{\dagger}$ Trace ammonium peak present below quant. limits
} 


\section{APPENDIX C. RUN DATA}

Data was collected throughout the run with automated equipment to record offgas composition, temperatures, helium and air purge flowrates, acid flowrates, acid cumulative flow, $\mathrm{pH}$, ORP, agitator speed and torque. This data is stored on a server. In addition, the weight of any solution added or removed is recorded to allow mass balances and other checks to be completed for each run. This is completed as an ancillary spreadsheet in the acid calculation spreadsheet. The checks and balances data for each run is reported below.

Table C1 SB6-1 Checks and Balances

Table C2 SB6-2 Checks and Balances

Table C3 SB6-3 Checks and Balances

Table C4 SB6-4 Checks and Balances

Table C5 SB6-5 Checks and Balances

Table C6 SB6-6 Checks and Balances 


\section{Table C1 SB6-1 Checks and Balances}

\begin{tabular}{|c|c|c|c|}
\hline SRAT Mass Balance SB6-1 & Planned, g & Actual, g & Delta, $g$ \\
\hline Sludge Simulant (grams) & $2,850.00$ & $2,850.00$ & 0.00 \\
\hline $\mathrm{AgNO}_{3}$ (grams) & 0.0016 & 0.0016 & 0.00 \\
\hline $\mathrm{HgO}$ (grams) & 8.3416 & 8.3419 & 0.00 \\
\hline $\mathrm{Pd}\left(\mathrm{NO}_{3}\right)_{2} * \mathrm{H}_{2} \mathrm{O}$ (grams solution) & 0.5329 & 0.5332 & 0.00 \\
\hline Coal/Carbon source (grams) & 0.0000 & 0.0000 & 0.00 \\
\hline $\mathrm{Rh}\left(\mathrm{NO}_{3}\right)_{3} * 2 \mathrm{H}_{2} \mathrm{O}$ (grams solution) & 2.0703 & 2.0701 & 0.00 \\
\hline $\mathrm{RuCl}_{3}$ (grams) & 0.9378 & 0.9381 & 0.00 \\
\hline Water to dilute/rinse trim chemicals (grams) & 50.00 & 50.00 & 0.00 \\
\hline Sodium Oxalate (grams) & 0.0000 & 0.0000 & 0.00 \\
\hline Total Slurry (grams) & $2,911.88$ & $2,911.88$ & 0.00 \\
\hline Sample Trimmed Sludge (grams) & 0.00 & 0.00 & 0.00 \\
\hline Slurry Mass after sample (grams) & $2,911.88$ & $2,911.88$ & 0.00 \\
\hline SRAT Antifoam (and water) (grams) & 46.48 & 46.46 & -0.02 \\
\hline Nitric Acid solution (grams) & 64.76 & 64.60 & -0.16 \\
\hline Formic Acid solution (grams) & 179.03 & 178.30 & -0.73 \\
\hline Total Dewater (grams) & 777.97 & 777.53 & 8.42 \\
\hline MWWT Dewater mass (grams) & & 0.16 & \\
\hline SRAT FAVC Dewater mass (grams) & & 8.70 & \\
\hline SRAT Sample \#1 (grams) & \multirow{9}{*}{250.00} & 15.44 & \multirow{9}{*}{-0.17} \\
\hline SRAT Sample \#2 (grams) & & 14.57 & \\
\hline SRAT Sample \#3 (grams) & & 12.69 & \\
\hline SRAT Sample \#4 (grams) & & 15.30 & \\
\hline SRAT Sample \#5 (grams) & & 2.52 & \\
\hline SRAT Sample \#6 (grams) & & 1.67 & \\
\hline SRAT Sample \#7 (grams) & & 13.94 & \\
\hline SRAT Product Sample \#1 (grams) & & 110.18 & \\
\hline SRAT Product Sample \#2 (grams) & & 63.52 & \\
\hline SRAT Product after sampling (grams) & & $2,102.98$ & \\
\hline SRAT Product Mass after sampling (grams) & $2,092.16$ & $2,102.98$ & 10.82 \\
\hline Expected Mass Loss $\left(\mathrm{CO}_{2}, \mathrm{NO}_{\mathrm{x}}\right.$, etc., g $)$ & 70.90 & 62.04 & \\
\hline Anion Conversion Balance (SRAT Cycle) & Planned, g & Actual, g & Delta \\
\hline \multicolumn{4}{|l|}{ SRAT Product Analysis: } \\
\hline SRAT Product Total Solids, wt \% & 25.00 & 26.10 & 1.1 \\
\hline SRAT Calcined Solids, wt \% & 15.81 & 16.15 & 0.3 \\
\hline SRAT Mn, wt. \% calcined element & 6.74 & 6.47 & \\
\hline SRAT Formate, $\mathrm{mg} / \mathrm{kg}$ & 52,773 & 54,600 & 1,827 \\
\hline SRAT Nitrite, $\mathrm{mg} / \mathrm{kg}$ & 0 & 200 & 200 \\
\hline SRAT Nitrate, $\mathrm{mg} / \mathrm{kg}$ & 29,057 & 27,000 & $-2,057$ \\
\hline SRAT Formate Added as acid (best basis, grams) & 157.936 & 157.292 & -1 \\
\hline Nitrate Added as acid (best basis, grams) & 32.213 & 32.133 & 0 \\
\hline Nitrite in Feed (grams) & 39.90 & 39.90 & 0 \\
\hline Nitrate in Feed \& trim chemicals (grams) & 25.09 & 25.09 & 0 \\
\hline Nitrite in SRAT product (grams) & 0.00 & 0.47 & 0 \\
\hline Nitrate in SRAT product (grams) & 68.06 & 63.53 & \\
\hline
\end{tabular}


SRNL-STI-2009-00413, REVISION 0

\begin{tabular}{|c|c|c|c|}
\hline Formate in SRAT product (grams) & 126.35 & 128.46 & \\
\hline SRAT Formate Destruction (grams) & 31.587 & 28.828 & -2.8 \\
\hline SRAT Formate Destruction (\%) planned/actual & 20.0 & 18.3 & -1.7 \\
\hline SRAT Nitrite Destruction (grams) & 39.9 & 39.4 & -0.5 \\
\hline SRAT Nitrite Destruction (\%) & 100.0 & 98.8 & -1.2 \\
\hline Nitrite to Nitrate Conversion (grams) & 10.76 & 6.30 & -4.5 \\
\hline Nitrate from nitrite in SRAT product, $\mathrm{mol}$ & 0.173 & 0.102 & -0.07 \\
\hline Moles of nitrite reacted & 0.867 & 0.857 & -0.010 \\
\hline $\begin{array}{l}\% \text { nitrite conversion to nitrate (SRAT product } \\
\text { based) }\end{array}$ & 20.0 & 11.9 & -8.1 \\
\hline Stop at SRAT Product Redox Check: & Planned & Actual & \\
\hline $\begin{array}{l}\text { Predicted SME product mass from forwarded SRAT } \\
\text { mass }\end{array}$ & 2361.6 & 2451.1 & \\
\hline Predicted SME Product Formate, gmol/kg SME slurry & 1.054 & 1.041 & \\
\hline Predicted SME Product Oxalate, gmol/kg SME slurry & 0.000 & 0.000 & \\
\hline Predicted SME Product Coal, gmol/kg SME slurry & 0.000 & 0.000 & \\
\hline Predicted SME Product Nitrate, gmol/kg SME slurry & 0.330 & 0.374 & \\
\hline Predicted SME Product Nitrite, gmol/kg SME slurry & 0.000 & 0.004 & \\
\hline Predicted SME Product Mn, gmol/kg SME slurry & 0.170 & 0.163 & \\
\hline Predicted $\mathrm{Fe}^{+2} / \mathrm{Fe}$ total in glass (no SME cycle) & 0.20 & 0.211 & \\
\hline & & & \\
\hline $\begin{array}{l}\text { SME Mass Balance SB6-1 } \\
\end{array}$ & Planned, $g$ & Actual, $g$ & Delta, $g$ \\
\hline SRAT Product Mass to SME cycle (grams) & $2,092.16$ & $2,102.98$ & 10.82 \\
\hline Calcined solids mass to SME cycle (grams) & 330.78 & 339.63 & 8.85 \\
\hline Canister Water Addition (grams) & 0.00 & 0.00 & 0.00 \\
\hline Canister Water Removal (grams) & 0.00 & 0.00 & 0.00 \\
\hline SME Antifoam Solution Addition (grams) & 4.18 & 4.18 & 0.00 \\
\hline Frit \#1 (grams) & 269.85 & 269.90 & 0.05 \\
\hline Frit \#2 (grams) & 269.85 & 269.90 & 0.05 \\
\hline Frit Water \#1 (grams) & 265.80 & 265.80 & 0.00 \\
\hline Frit Water \#2 (grams) & 265.80 & 265.80 & 0.00 \\
\hline Formic Acid \#1 (grams) & 4.05 & 4.05 & 0.00 \\
\hline Formic Acid \#2 (grams) & 4.05 & 4.05 & 0.00 \\
\hline SME Dewater \#1 (grams) & 269.85 & 263.10 & -6.75 \\
\hline SME Dewater \#2 (grams) & 269.85 & 265.77 & -4.08 \\
\hline Final SME Dewater (grams) & 257.75 & 269.02 & 11.27 \\
\hline SME FAVC (grams) & 0.00 & 0.76 & 0.76 \\
\hline Total Dewater (grams) & 797.45 & 798.65 & 1.20 \\
\hline SME Product Sample \#1 (grams) & & 148.70 & \\
\hline SME Product Sample \#2 (grams) & & 151.54 & \\
\hline SME Product after sampling (grams) & & $2,007.50$ & \\
\hline Potential Total SME Product (no samples removed, g) & $2,378.30$ & $2,307.74$ & -70.56 \\
\hline Expected Mass Loss $\left(\mathrm{CO}_{2}, \mathrm{NO}_{\mathrm{x}}\right.$, etc., $\left.\mathrm{g}\right)$ & 0.00 & 80.27 & \\
\hline Projected SME Product Waste Loading, $\%$ & 38.00 & 38.62 & \\
\hline Predicted SME Product Mass (Acid Calc's, g) & $2,378.30$ & & \\
\hline Anion Conversion Balance (SME Cycle) & Planned, $g$ & Actual, $\mathbf{g}$ & Delta \\
\hline
\end{tabular}


SRNL-STI-2009-00413, REVISION 0

\begin{tabular}{|l|c|c|c|}
\hline SME Product Analysis: & & & \\
\hline SME Product Total Solids, wt \% & 45.00 & 46.8 & 2 \\
\hline SME Calcined Solids, wt \% & 36.60 & 38 & 1 \\
\hline SME Manganese, calcined wt \% & 2.55 & 2.44 & \\
\hline SME Formate, $\mathrm{mg} / \mathrm{kg}$ & 45,407 & 49,700 & 4,293 \\
\hline SME Oxalate, $\mathrm{mg} / \mathrm{kg}$ & 0 & 0 & \\
\hline SME Nitrate, $\mathrm{mg} / \mathrm{kg}$ & 23,005 & 23,600 & 595 \\
\hline SME Nitrite, $\mathrm{mg} / \mathrm{kg}$ & 0 & 0 & \\
\hline SME Feed formate (grams) & 112.86 & 114.82 & \\
\hline SME Feed nitrate (grams) & 60.79 & 56.78 & \\
\hline SME Formate Added as acid (best basis, grams) & 7.13 & 7.13 & \\
\hline Nitrate in SME product (grams) & 54.71 & 54.46 & \\
\hline Formate in SME product (grams) & 107.99 & 114.69 & \\
\hline SME Formate Destruction (grams) & 12.00 & 7.26 & \\
\hline SME Formate Destruction (\%) planned/actual & $\mathbf{1 0 . 0}$ & $\mathbf{6 . 0}$ & \\
\hline SME Nitrate Destruction (grams) & 6.08 & 2.32 & \\
\hline SME Nitrate Destruction (\%) planned/actual & $\mathbf{1 0 . 0}$ & $\mathbf{4 . 1}$ & \\
\hline SME Product Formate, gmol/kg SME slurry & 1.009 & 1.104 & \\
\hline SME Product Oxalate, gmol/kg SME slurry & 0.000 & 0.000 & \\
\hline SME Product Coal, gmol/kg SME slurry & 0.000 & 0.000 & \\
\hline SME Product Nitrate, gmol/kg SME slurry & 0.371 & 0.381 & \\
\hline SME Product Nitrite, gmol/kg SME slurry & 0.000 & 0.000 & \\
\hline SME Product Manganese, gmol/kg SME slurry & 0.170 & 0.169 & \\
\hline Predicted Fe /Fe total in glass & $\mathbf{0 . 2 0 0}$ & $\mathbf{0 . 2 3 0}$ & \\
\hline
\end{tabular}




\section{Table C2 SB6-2 Checks and Balances}

\begin{tabular}{|c|c|c|c|}
\hline SRAT Mass Balance SB6-2 & Planned, g & Actual, g & Delta, $g$ \\
\hline Sludge Simulant (grams) & $2,850.00$ & $2,850.00$ & 0.00 \\
\hline $\mathrm{AgNO}_{3}$ (grams) & 0.0016 & 0.0015 & 0.00 \\
\hline $\mathrm{HgO}$ (grams) & 8.3416 & 8.3432 & 0.00 \\
\hline $\mathrm{Pd}\left(\mathrm{NO}_{3}\right)_{2} * \mathrm{H}_{2} \mathrm{O}$ (grams solution) & 0.5329 & 0.5340 & 0.00 \\
\hline Coal/Carbon source (grams) & 0.0000 & 0.0000 & 0.00 \\
\hline $\mathrm{Rh}\left(\mathrm{NO}_{3}\right)_{3} * 2 \mathrm{H}_{2} \mathrm{O}$ (grams solution) & 2.0703 & 2.0713 & 0.00 \\
\hline $\mathrm{RuCl}_{3}$ (grams) & 0.9378 & 0.9321 & -0.01 \\
\hline Water to dilute/rinse trim chemicals (grams) & 50.00 & 50.00 & 0.00 \\
\hline Sodium Oxalate (grams) & 0.0000 & 0.0000 & 0.00 \\
\hline Total Slurry (grams) & $2,911.88$ & $2,911.88$ & 0.00 \\
\hline Sample Trimmed Sludge (grams) & 0.00 & 0.00 & 0.00 \\
\hline Slurry Mass after sample (grams) & $2,911.88$ & $2,911.88$ & 0.00 \\
\hline SRAT Antifoam (and water) (grams) & 46.48 & 46.46 & -0.02 \\
\hline Nitric Acid solution (grams) & 52.47 & 52.40 & -0.07 \\
\hline Formic Acid solution (grams) & 163.51 & 163.00 & -0.51 \\
\hline Total Dewater (grams) & 822.59 & 826.30 & 24.90 \\
\hline MWWT Dewater mass (grams) & & 7.48 & \\
\hline SRAT FAVC Dewater mass (grams) & & 13.71 & \\
\hline SRAT Sample \#1 (grams) & \multirow{9}{*}{250.00} & 15.73 & \multirow{9}{*}{2.41} \\
\hline SRAT Sample \#2 (grams) & & 13.78 & \\
\hline SRAT Sample \#3 (grams) & & 12.99 & \\
\hline SRAT Sample \#4 (grams) & & 14.40 & \\
\hline SRAT Sample \#5 (grams) & & 1.57 & \\
\hline SRAT Sample \#6 (grams) & & 2.24 & \\
\hline SRAT Sample \#7 (grams) & & 13.99 & \\
\hline SRAT Product Sample \#1 (grams) & & 102.12 & \\
\hline SRAT Product Sample \#2 (grams) & & 75.59 & \\
\hline SRAT Product after sampling (grams) & & $2,026.93$ & \\
\hline SRAT Product Mass after sampling (grams) & $2,022.53$ & $2,026.93$ & 4.40 \\
\hline Expected Mass Loss $\left(\mathrm{CO}_{2}, \mathrm{NO}_{\mathrm{x}}\right.$, etc., g $)$ & 68.10 & 46.91 & \\
\hline Anion Conversion Balance (SRAT Cycle) & Planned, g & Actual, g & Delta \\
\hline \multicolumn{4}{|l|}{ SRAT Product Analysis: } \\
\hline SRAT Product Total Solids, wt \% & 25.00 & 26.30 & 1.3 \\
\hline SRAT Calcined Solids, wt \% & 16.30 & 15.8 & -0.5 \\
\hline SRAT Mn, wt. \% calcined element & 6.74 & 6.49 & \\
\hline SRAT Formate, $\mathrm{mg} / \mathrm{kg}$ & 49,674 & 52,550 & 2,876 \\
\hline SRAT Nitrite, mg/kg & 0 & 1,960 & 1,960 \\
\hline SRAT Nitrate, $\mathrm{mg} / \mathrm{kg}$ & 27,259 & 24,650 & $-2,609$ \\
\hline SRAT Formate Added as acid (best basis, grams) & 144.241 & 143.795 & 0 \\
\hline Nitrate Added as acid (best basis, grams) & 26.102 & 26.065 & 0 \\
\hline Nitrite in Feed (grams) & 39.90 & 39.90 & 0 \\
\hline Nitrate in Feed \& trim chemicals (grams) & 25.09 & 25.09 & 0 \\
\hline Nitrite in SRAT product (grams) & 0.00 & 4.47 & 4 \\
\hline Nitrate in SRAT product (grams) & 61.95 & 56.19 & \\
\hline
\end{tabular}


SRNL-STI-2009-00413, REVISION 0

\begin{tabular}{|c|c|c|c|}
\hline Formate in SRAT product (grams) & 115.39 & 119.78 & \\
\hline SRAT Formate Destruction (grams) & 28.848 & 24.015 & -4.8 \\
\hline SRAT Formate Destruction (\%) planned/actual & 20.0 & 16.7 & -3.3 \\
\hline SRAT Nitrite Destruction (grams) & 39.9 & 35.4 & -4.5 \\
\hline SRAT Nitrite Destruction (\%) & 100.0 & 88.8 & -11.2 \\
\hline Nitrite to Nitrate Conversion (grams) & 10.76 & 5.03 & -5.7 \\
\hline Nitrate from nitrite in SRAT product, mol & 0.173 & 0.081 & -0.09 \\
\hline Moles of nitrite reacted & 0.867 & 0.770 & -0.097 \\
\hline $\begin{array}{l}\% \text { nitrite conversion to nitrate (SRAT product } \\
\text { based) }\end{array}$ & 20.0 & 10.5 & -9.5 \\
\hline Stop at SRAT Product Redox Check: & Planned & Actual & \\
\hline $\begin{array}{l}\text { Predicted SME product mass from forwarded SRAT } \\
\text { mass }\end{array}$ & 2318.6 & 2345.8 & \\
\hline Predicted SME Product Formate, gmol/kg SME slurry & 0.977 & 1.009 & \\
\hline Predicted SME Product Oxalate, gmol/kg SME slurry & 0.000 & 0.000 & \\
\hline Predicted SME Product Coal, gmol/kg SME slurry & 0.000 & 0.000 & \\
\hline Predicted SME Product Nitrate, gmol/kg SME slurry & 0.305 & 0.343 & \\
\hline Predicted SME Product Nitrite, gmol/kg SME slurry & 0.000 & 0.037 & \\
\hline Predicted SME Product Mn, gmol/kg SME slurry & 0.172 & 0.161 & \\
\hline Predicted $\mathrm{Fe}^{+2} / \mathrm{Fe}$ total in glass (no SME cycle) & 0.20 & 0.196 & \\
\hline $\begin{array}{r}\text { SME Mass Balance SB6-2 } \\
\end{array}$ & Planned, g & Actual, g & Delta, $g$ \\
\hline SRAT Product Mass to SME cycle (grams) & $2,022.53$ & $2,026.93$ & 4.40 \\
\hline Calcined solids mass to SME cycle (grams) & 329.57 & 320.26 & -9.32 \\
\hline Canister Water Addition (grams) & 0.00 & 0.00 & 0.00 \\
\hline Canister Water Removal (grams) & 0.00 & 0.00 & 0.00 \\
\hline SME Antifoam Solution Addition (grams) & 4.05 & 4.04 & -0.01 \\
\hline Frit \#1 (grams) & 268.86 & 268.90 & 0.04 \\
\hline Frit \#2 (grams) & 268.86 & 268.90 & 0.04 \\
\hline Frit Water \#1 (grams) & 264.83 & 264.80 & -0.03 \\
\hline Frit Water \#2 (grams) & 264.83 & 264.80 & -0.03 \\
\hline Formic Acid \#1 (grams) & 4.03 & 4.03 & 0.00 \\
\hline Formic Acid \#2 (grams) & 4.03 & 4.03 & 0.00 \\
\hline SME Dewater \#1 (grams) & 268.86 & 267.97 & -0.89 \\
\hline SME Dewater \#2 (grams) & 268.86 & 269.21 & 0.35 \\
\hline Final SME Dewater (grams) & 229.15 & 229.49 & 0.34 \\
\hline SME FAVC (grams) & 0.00 & 0.94 & 0.94 \\
\hline Total Dewater (grams) & 766.87 & 767.61 & 0.74 \\
\hline SME Product Sample \#1 (grams) & & 138.72 & \\
\hline SME Product Sample \#2 (grams) & & 140.81 & \\
\hline SME Product after sampling (grams) & & $1,966.50$ & \\
\hline Potential Total SME Product (no samples removed, g) & $2,335.15$ & $2,246.03$ & -89.12 \\
\hline Expected Mass Loss $\left(\mathrm{CO}_{2}, \mathrm{NO}_{\mathrm{x}}\right.$, etc., $\left.\mathrm{g}\right)$ & 0.00 & 92.79 & \\
\hline Projected SME Product Waste Loading, \% & 38.00 & 37.32 & \\
\hline Predicted SME Product Mass (Acid Calc's, g) & $2,335.15$ & & \\
\hline Anion Conversion Balance (SME Cycle) & Planned, g & Actual, $g$ & Delta \\
\hline SME Product Analysis: & & & \\
\hline
\end{tabular}


SRNL-STI-2009-00413, REVISION 0

\begin{tabular}{|l|c|c|c|}
\hline SME Product Total Solids, wt \% & 45.00 & 47.15 & 2 \\
\hline SME Calcined Solids, wt \% & 37.14 & 38.55 & 1 \\
\hline SME Manganese, calcined wt \% & 2.55 & 2.39 & \\
\hline SME Formate, $\mathrm{mg} / \mathrm{kg}$ & 42,318 & 47,500 & 5,182 \\
\hline SME Oxalate, $\mathrm{mg} / \mathrm{kg}$ & 0 & 0 & \\
\hline SME Nitrate, $\mathrm{mg} / \mathrm{kg}$ & 21,248 & 21,500 & 252 \\
\hline SME Nitrite, $\mathrm{mg} / \mathrm{kg}$ & 0 & 0 & \\
\hline SME Feed formate (grams) & 102.70 & 106.52 & \\
\hline SME Feed nitrate (grams) & 55.13 & 49.96 & \\
\hline SME Formate Added as acid (best basis, grams) & 7.10 & 7.10 & \\
\hline Nitrate in SME product (grams) & 49.62 & 48.29 & \\
\hline Formate in SME product (grams) & 98.82 & 106.69 & \\
\hline SME Formate Destruction (grams) & 10.98 & 6.93 & \\
\hline SME Formate Destruction (\%) planned/actual & $\mathbf{1 0 . 0}$ & $\mathbf{6 . 1}$ & \\
\hline SME Nitrate Destruction (grams) & 5.51 & 1.67 & \\
\hline SME Nitrate Destruction (\%) planned/actual & $\mathbf{1 0 . 0}$ & $\mathbf{3 . 4}$ & \\
\hline SME Product Formate, gmol/kg SME slurry & 0.940 & 1.055 & \\
\hline SME Product Oxalate, gmol/kg SME slurry & 0.000 & 0.000 & \\
\hline SME Product Coal, gmol/kg SME slurry & 0.000 & 0.000 & \\
\hline SME Product Nitrate, gmol/kg SME slurry & 0.343 & 0.347 & \\
\hline SME Product Nitrite, gmol/kg SME slurry & 0.000 & 0.000 & \\
\hline SME Product Manganese, gmol/kg SME slurry & 0.172 & 0.168 & \\
\hline Predicted Fe /Fe total in glass & $\mathbf{0 . 2 0 0}$ & $\mathbf{0 . 2 4 4}$ & \\
\hline
\end{tabular}




\section{Table C3 SB6-3 Checks and Balances}

\begin{tabular}{|c|c|c|c|}
\hline SRAT Mass Balance SB6-3 & Planned, g & Actual, g & Delta, $g$ \\
\hline Sludge Simulant (grams) & $2,850.00$ & $2,850.00$ & 0.00 \\
\hline $\mathrm{AgNO}_{3}$ (grams) & 0.0016 & 0.0025 & 0.00 \\
\hline $\mathrm{HgO}$ (grams) & 8.3416 & 8.3412 & 0.00 \\
\hline $\mathrm{Pd}\left(\mathrm{NO}_{3}\right)_{2} * \mathrm{H}_{2} \mathrm{O}$ (grams solution) & 0.5329 & 0.5393 & 0.01 \\
\hline Coal/Carbon source (grams) & 0.0000 & 0.0000 & 0.00 \\
\hline $\mathrm{Rh}\left(\mathrm{NO}_{3}\right)_{3} * 2 \mathrm{H}_{2} \mathrm{O}$ (grams solution) & 2.0703 & 2.0719 & 0.00 \\
\hline $\mathrm{RuCl}_{3}$ (grams) & 0.9378 & 0.9381 & 0.00 \\
\hline Water to dilute/rinse trim chemicals (grams) & 50.00 & 50.00 & 0.00 \\
\hline Sodium Oxalate (grams) & 0.0000 & 0.0000 & 0.00 \\
\hline Total Slurry (grams) & $2,911.88$ & $2,911.89$ & 0.01 \\
\hline Sample Trimmed Sludge (grams) & 0.00 & 0.00 & 0.00 \\
\hline Slurry Mass after sample (grams) & $2,911.88$ & $2,911.89$ & 0.01 \\
\hline SRAT Antifoam (and water) (grams) & 46.48 & 46.47 & -0.01 \\
\hline Nitric Acid solution (grams) & 89.39 & 89.20 & -0.19 \\
\hline Formic Acid solution (grams) & 210.05 & 209.40 & -0.65 \\
\hline Total Dewater (grams) & 688.72 & 688.40 & 14.50 \\
\hline MWWT Dewater mass (grams) & & 0.63 & \\
\hline SRAT FAVC Dewater mass (grams) & & 14.19 & \\
\hline SRAT Sample \#1 (grams) & \multirow{9}{*}{250.00} & 15.72 & \multirow{9}{*}{11.25} \\
\hline SRAT Sample \#2 (grams) & & 15.98 & \\
\hline SRAT Sample \#3 (grams) & & 14.09 & \\
\hline SRAT Sample \#4 (grams) & & 15.81 & \\
\hline SRAT Sample \#5 (grams) & & 2.05 & \\
\hline SRAT Sample \#6 (grams) & & 1.08 & \\
\hline SRAT Sample \#7 (grams) & & 14.27 & \\
\hline SRAT Product Sample \#1 (grams) & & 104.84 & \\
\hline SRAT Product Sample \#2 (grams) & & 77.40 & \\
\hline SRAT Product after sampling (grams) & & $2,230.82$ & \\
\hline SRAT Product Mass after sampling (grams) & $2,231.48$ & $2,230.82$ & -0.66 \\
\hline Expected Mass Loss $\left(\mathrm{CO}_{2}, \mathrm{NO}_{\mathrm{x}}\right.$, etc., g $)$ & 76.50 & 75.95 & \\
\hline Anion Conversion Balance (SRAT Cycle) & Planned, g & Actual, g & Delta \\
\hline \multicolumn{4}{|l|}{ SRAT Product Analysis: } \\
\hline SRAT Product Total Solids, wt \% & 25.00 & 25.30 & 0.3 \\
\hline SRAT Calcined Solids, wt \% & 14.92 & 15.2 & 0.3 \\
\hline SRAT Mn, wt. \% calcined element & 6.74 & 6.26 & \\
\hline SRAT Formate, $\mathrm{mg} / \mathrm{kg}$ & 58,441 & 57,600 & -841 \\
\hline SRAT Nitrite, $\mathrm{mg} / \mathrm{kg}$ & 0 & 0 & 0 \\
\hline SRAT Nitrate, $\mathrm{mg} / \mathrm{kg}$ & 32,364 & 31,900 & -464 \\
\hline SRAT Formate Added as acid (best basis, grams) & 185.303 & 184.727 & -1 \\
\hline Nitrate Added as acid (best basis, grams) & 44.466 & 44.370 & 0 \\
\hline Nitrite in Feed (grams) & 39.90 & 39.90 & 0 \\
\hline Nitrate in Feed \& trim chemicals (grams) & 25.09 & 25.09 & 0 \\
\hline Nitrite in SRAT product (grams) & 0.00 & 0.00 & 0 \\
\hline Nitrate in SRAT product (grams) & 80.31 & 79.50 & \\
\hline
\end{tabular}


SRNL-STI-2009-00413, REVISION 0

\begin{tabular}{|c|c|c|c|}
\hline Formate in SRAT product (grams) & 148.24 & 143.54 & \\
\hline SRAT Formate Destruction (grams) & 37.061 & 41.185 & 4.1 \\
\hline SRAT Formate Destruction (\%) planned/actual & 20.0 & 22.3 & 2.3 \\
\hline SRAT Nitrite Destruction (grams) & 39.9 & 39.9 & 0.0 \\
\hline SRAT Nitrite Destruction (\%) & 100.0 & 100.0 & 0.0 \\
\hline Nitrite to Nitrate Conversion (grams) & 10.76 & 10.04 & -0.7 \\
\hline Nitrate from nitrite in SRAT product, $\mathrm{mol}$ & 0.173 & 0.162 & -0.01 \\
\hline Moles of nitrite reacted & 0.867 & 0.867 & 0.000 \\
\hline $\begin{array}{l}\% \text { nitrite conversion to nitrate (SRAT product } \\
\text { based) }\end{array}$ & 20.0 & 18.7 & -1.3 \\
\hline Stop at SRAT Product Redox Check: & Planned & Actual & \\
\hline $\begin{array}{l}\text { Predicted SME product mass from forwarded SRAT } \\
\text { mass }\end{array}$ & 2447.1 & 2483.6 & \\
\hline Predicted SME Product Formate, gmol/kg SME slurry & 1.202 & 1.149 & \\
\hline Predicted SME Product Oxalate, gmol/kg SME slurry & 0.000 & 0.000 & \\
\hline Predicted SME Product Coal, gmol/kg SME slurry & 0.000 & 0.000 & \\
\hline Predicted SME Product Nitrate, gmol/kg SME slurry & 0.378 & 0.462 & \\
\hline Predicted SME Product Nitrite, gmol/kg SME slurry & 0.000 & 0.000 & \\
\hline Predicted SME Product Mn, gmol/kg SME slurry & 0.165 & 0.156 & \\
\hline Predicted $\mathrm{Fe}^{+2} / \mathrm{Fe}$ total in glass (no SME cycle) & 0.200 & 0.173 & \\
\hline & & & \\
\hline SME Mass Balance SB6-3 & Planned, $g$ & Actual, $g$ & Delta, $g$ \\
\hline SRAT Product Mass to SME cycle (grams) & $2,231.48$ & $2,230.82$ & -0.66 \\
\hline Calcined solids mass to SME cycle (grams) & 333.00 & 339.08 & 6.08 \\
\hline Canister Water Addition (grams) & 0.00 & 0.00 & 0.00 \\
\hline Canister Water Removal (grams) & 0.00 & 0.00 & 0.00 \\
\hline SME Antifoam Solution Addition (grams) & 4.46 & 4.46 & 0.00 \\
\hline Frit \#1 (grams) & 271.66 & 271.70 & 0.04 \\
\hline Frit \#2 (grams) & 271.66 & 271.70 & 0.04 \\
\hline Frit Water \#1 (grams) & 267.59 & 267.60 & 0.01 \\
\hline Frit Water \#2 (grams) & 267.59 & 267.60 & 0.01 \\
\hline Formic Acid \#1 (grams) & 4.07 & 4.07 & 0.00 \\
\hline Formic Acid \#2 (grams) & 4.07 & 4.07 & 0.00 \\
\hline SME Dewater \#1 (grams) & 271.66 & 273.06 & 1.40 \\
\hline SME Dewater \#2 (grams) & 271.66 & 279.20 & 7.54 \\
\hline Final SME Dewater (grams) & 315.38 & 306.46 & -8.92 \\
\hline SME FAVC (grams) & 0.00 & 1.86 & 1.86 \\
\hline Total Dewater (grams) & 858.70 & 860.58 & 1.88 \\
\hline SME Product Sample \#1 (grams) & & 145.88 & \\
\hline SME Product Sample \#2 (grams) & & 140.62 & \\
\hline SME Product after sampling (grams) & & $2,109.20$ & \\
\hline Potential Total SME Product (no samples removed, g) & $2,463.88$ & $2,395.70$ & -68.18 \\
\hline Expected Mass Loss $\left(\mathrm{CO}_{2}, \mathrm{NO}_{\mathrm{x}}\right.$, etc., $\left.\mathrm{g}\right)$ & 0.00 & 65.74 & \\
\hline Projected SME Product Waste Loading, $\%$ & 38.00 & 38.42 & \\
\hline Predicted SME Product Mass (Acid Calc's, g) & $2,463.88$ & & \\
\hline Anion Conversion Balance (SME Cycle) & Planned, $g$ & Actual, $\mathbf{g}$ & Delta \\
\hline
\end{tabular}


SRNL-STI-2009-00413, REVISION 0

\begin{tabular}{|l|c|c|c|}
\hline SME Product Analysis: & & & \\
\hline SME Product Total Solids, wt \% & 45.00 & 46.4 & 1 \\
\hline SME Calcined Solids, wt \% & 35.57 & 36.9 & 1 \\
\hline SME Manganese, calcined wt \% & 2.55 & 2.37 & \\
\hline SME Formate, $\mathrm{mg} / \mathrm{kg}$ & 51,315 & 55,050 & 3,735 \\
\hline SME Oxalate, $\mathrm{mg} / \mathrm{kg}$ & 0 & 0 & \\
\hline SME Nitrate, $\mathrm{mg} / \mathrm{kg}$ & 26,380 & 28,350 & 1,970 \\
\hline SME Nitrite, $\mathrm{mg} / \mathrm{kg}$ & 0 & 0 & \\
\hline SME Feed formate (grams) & 133.31 & 128.50 & \\
\hline SME Feed nitrate (grams) & 72.22 & 71.16 & \\
\hline SME Formate Added as acid (best basis, grams) & 7.18 & 7.17 & \\
\hline Nitrate in SME product (grams) & 65.00 & 67.92 & \\
\hline Formate in SME product (grams) & 126.43 & 131.88 & \\
\hline SME Formate Destruction (grams) & 14.05 & 3.78 & \\
\hline SME Formate Destruction (\%) planned/actual & $\mathbf{1 0 . 0}$ & $\mathbf{2 . 8}$ & \\
\hline SME Nitrate Destruction (grams) & 7.22 & 3.24 & \\
\hline SME Nitrate Destruction (\%) planned/actual & $\mathbf{1 0 . 0}$ & $\mathbf{4 . 6}$ & \\
\hline SME Product Formate, gmol/kg SME slurry & 1.140 & 1.223 & \\
\hline SME Product Oxalate, gmol/kg SME slurry & 0.000 & 0.000 & \\
\hline SME Product Coal, gmol/kg SME slurry & 0.000 & 0.000 & \\
\hline SME Product Nitrate, gmol/kg SME slurry & 0.425 & 0.457 & \\
\hline SME Product Nitrite, gmol/kg SME slurry & 0.000 & 0.000 & \\
\hline SME Product Manganese, gmol/kg SME slurry & 0.165 & 0.159 & \\
\hline Predicted Fe ${ }^{+2} /$ Fe total in glass & $\mathbf{0 . 2 0 0}$ & $\mathbf{0 . 2 0 5}$ & \\
\hline
\end{tabular}




\section{Table C4 SB6-4 Checks and Balances}

\begin{tabular}{|c|c|c|c|}
\hline SRAT Mass Balance SB6-4 & Planned, g & Actual, g & Delta, $g$ \\
\hline Sludge Simulant (grams) & $2,850.00$ & $2,850.00$ & 0.00 \\
\hline $\mathrm{AgNO}_{3}$ (grams) & 0.0016 & 0.0018 & 0.00 \\
\hline $\mathrm{HgO}$ (grams) & 8.3416 & 8.3415 & 0.00 \\
\hline $\mathrm{Pd}\left(\mathrm{NO}_{3}\right)_{2} * \mathrm{H}_{2} \mathrm{O}$ (grams solution) & 0.5329 & 0.5333 & 0.00 \\
\hline Coal/Carbon source (grams) & 0.0000 & 0.0000 & 0.00 \\
\hline $\mathrm{Rh}\left(\mathrm{NO}_{3}\right)_{3} * 2 \mathrm{H}_{2} \mathrm{O}$ (grams solution) & 2.0703 & 2.0702 & 0.00 \\
\hline $\mathrm{RuCl}_{3}$ (grams) & 0.9378 & 0.9381 & 0.00 \\
\hline Water to dilute/rinse trim chemicals (grams) & 50.00 & 50.00 & 0.00 \\
\hline Sodium Oxalate (grams) & 0.0000 & 0.0000 & 0.00 \\
\hline Total Slurry (grams) & $2,911.88$ & $2,911.88$ & 0.00 \\
\hline Sample Trimmed Sludge (grams) & 0.00 & 0.00 & 0.00 \\
\hline Slurry Mass after sample (grams) & $2,911.88$ & $2,911.88$ & 0.00 \\
\hline ARP Simulant & 0.00 & 0.00 & 0.00 \\
\hline Nitric Acid solution (grams) & 126.27 & 126.00 & -0.27 \\
\hline Formic Acid solution (grams) & 256.61 & 256.00 & -0.61 \\
\hline Total Dewater (grams) & 554.85 & 555.80 & 9.57 \\
\hline MWWT Dewater mass (grams) & & -4.67 & \\
\hline SRAT FAVC Dewater mass (grams) & & 13.30 & \\
\hline SRAT Sample \#1 (grams) & \multirow{9}{*}{250.00} & 15.30 & \multirow{9}{*}{0.01} \\
\hline SRAT Sample \#2 (grams) & & 14.57 & \\
\hline SRAT Sample \#3 (grams) & & 14.00 & \\
\hline SRAT Sample \#4 (grams) & & 16.38 & \\
\hline SRAT Sample \#5 (grams) & & 1.23 & \\
\hline SRAT Sample \#6 (grams) & & 1.18 & \\
\hline SRAT Sample \#7 (grams) & & 13.29 & \\
\hline SRAT Product Sample \#1 (grams) & & 98.84 & \\
\hline SRAT Product Sample \#2 (grams) & & 75.22 & \\
\hline SRAT Product after sampling (grams) & & $2,449.65$ & \\
\hline SRAT Product Mass after sampling (grams) & $2,440.39$ & $2,449.65$ & 9.26 \\
\hline Expected Mass Loss $\left(\mathrm{CO}_{2}, \mathrm{NO}_{\mathrm{x}}\right.$, etc., g $)$ & 84.89 & 89.56 & \\
\hline Anion Conversion Balance (SRAT Cycle) & Planned, g & Actual, g & Delta \\
\hline \multicolumn{4}{|l|}{ SRAT Product Analysis: } \\
\hline SRAT Product Total Solids, wt \% & 25.00 & 25.80 & 0.8 \\
\hline SRAT Calcined Solids, wt \% & 13.76 & 14.3 & 0.5 \\
\hline SRAT Mn, wt. \% calcined element & 6.74 & 6.49 & \\
\hline SRAT Formate, $\mathrm{mg} / \mathrm{kg}$ & 65,852 & 67,050 & 1,198 \\
\hline SRAT Nitrite, $\mathrm{mg} / \mathrm{kg}$ & 0 & 0 & 0 \\
\hline SRAT Nitrate, $\mathrm{mg} / \mathrm{kg}$ & 36,670 & 37,700 & 1,030 \\
\hline SRAT Formate Added as acid (best basis, grams) & 226.379 & 225.837 & -1 \\
\hline Nitrate Added as acid (best basis, grams) & 62.811 & 62.675 & 0 \\
\hline Nitrite in Feed (grams) & 39.90 & 39.90 & 0 \\
\hline Nitrate in Feed \& trim chemicals (grams) & 25.09 & 25.09 & 0 \\
\hline Nitrite in SRAT product (grams) & 0.00 & 0.00 & 0 \\
\hline Nitrate in SRAT product (grams) & 98.66 & 101.78 & \\
\hline
\end{tabular}


SRNL-STI-2009-00413, REVISION 0

\begin{tabular}{|c|c|c|c|}
\hline Formate in SRAT product (grams) & 181.10 & 181.01 & \\
\hline SRAT Formate Destruction (grams) & 45.276 & 44.825 & -0.5 \\
\hline SRAT Formate Destruction (\%) planned/actual & 20.0 & 19.8 & -0.2 \\
\hline SRAT Nitrite Destruction (grams) & 39.9 & 39.9 & 0.0 \\
\hline SRAT Nitrite Destruction (\%) & 100.0 & 100.0 & 0.0 \\
\hline Nitrite to Nitrate Conversion (grams) & 10.76 & 14.01 & 3.3 \\
\hline Nitrate from nitrite in SRAT product, $\mathrm{mol}$ & 0.173 & 0.226 & 0.05 \\
\hline Moles of nitrite reacted & 0.867 & 0.867 & 0.000 \\
\hline $\begin{array}{l}\% \text { nitrite conversion to nitrate (SRAT product } \\
\text { based) }\end{array}$ & 20.0 & 26.1 & 6.1 \\
\hline Stop at SRAT Product Redox Check: & Planned & Actual & \\
\hline $\begin{array}{l}\text { Predicted SME product mass from forwarded SRAT } \\
\text { mass }\end{array}$ & 2573.7 & 2674.6 & \\
\hline Predicted SME Product Formate, gmol/kg SME slurry & 1.409 & 1.364 & \\
\hline Predicted SME Product Oxalate, gmol/kg SME slurry & 0.000 & 0.000 & \\
\hline Predicted SME Product Coal, gmol/kg SME slurry & 0.000 & 0.000 & \\
\hline Predicted SME Product Nitrate, gmol/kg SME slurry & 0.446 & 0.557 & \\
\hline Predicted SME Product Nitrite, gmol/kg SME slurry & 0.000 & 0.000 & \\
\hline Predicted SME Product Mn, gmol/kg SME slurry & 0.158 & 0.155 & \\
\hline Predicted $\mathrm{Fe}^{+2} / \mathrm{Fe}$ total in glass (no SME cycle) & 0.200 & 0.167 & \\
\hline & & & \\
\hline SME Mass Balance SB6-4 & Planned, $g$ & Actual, $g$ & Delta, $g$ \\
\hline SRAT Product Mass to SME cycle (grams) & $2,440.39$ & $2,449.65$ & 9.26 \\
\hline Calcined solids mass to SME cycle (grams) & 335.90 & 350.30 & 14.40 \\
\hline Canister Water Addition (grams) & 0.00 & 0.00 & 0.00 \\
\hline Canister Water Removal (grams) & 0.00 & 0.00 & 0.00 \\
\hline SME Antifoam Solution Addition (grams) & 4.88 & 4.88 & 0.00 \\
\hline Frit \#1 (grams) & 274.02 & 274.00 & -0.02 \\
\hline Frit \#2 (grams) & 274.02 & 274.00 & -0.02 \\
\hline Frit Water \#1 (grams) & 269.91 & 269.90 & -0.01 \\
\hline Frit Water \#2 (grams) & 269.91 & 269.90 & -0.01 \\
\hline Formic Acid \#1 (grams) & 4.11 & 4.11 & 0.00 \\
\hline Formic Acid \#2 (grams) & 4.11 & 4.11 & 0.00 \\
\hline SME Dewater \#1 (grams) & 274.02 & 281.97 & 7.95 \\
\hline SME Dewater \#2 (grams) & 274.02 & 274.01 & -0.01 \\
\hline Final SME Dewater (grams) & 402.68 & 394.78 & -7.90 \\
\hline SME FAVC (grams) & 0.00 & 1.57 & 1.57 \\
\hline Total Dewater (grams) & 950.73 & 952.33 & 1.60 \\
\hline SME Product Sample \#1 (grams) & & 151.13 & \\
\hline SME Product Sample \#2 (grams) & & 153.16 & \\
\hline SME Product after sampling (grams) & & $2,227.90$ & \\
\hline Potential Total SME Product (no samples removed, g) & $2,590.64$ & $2,532.19$ & -58.45 \\
\hline Expected Mass Loss $\left(\mathrm{CO}_{2}, \mathrm{NO}_{\mathrm{x}}\right.$, etc., $\left.\mathrm{g}\right)$ & 0.00 & 66.03 & \\
\hline Projected SME Product Waste Loading, $\%$ & 38.00 & 39.00 & \\
\hline Predicted SME Product Mass (Acid Calc's, g) & $2,590.64$ & & \\
\hline Anion Conversion Balance (SME Cycle) & Planned, $g$ & Actual, $\mathbf{g}$ & Delta \\
\hline
\end{tabular}


SRNL-STI-2009-00413, REVISION 0

\begin{tabular}{|l|c|c|c|}
\hline SME Product Analysis: & & & \\
\hline SME Product Total Solids, wt \% & 45.00 & 47.4 & 2 \\
\hline SME Calcined Solids, wt \% & 34.12 & 36.9 & 3 \\
\hline SME Manganese, calcined wt \% & 2.55 & 2.29 & \\
\hline SME Formate, $\mathrm{mg} / \mathrm{kg}$ & 59,584 & 60,750 & 1,166 \\
\hline SME Oxalate, $\mathrm{mg} / \mathrm{kg}$ & 0 & 0 & \\
\hline SME Nitrate, $\mathrm{mg} / \mathrm{kg}$ & 31,089 & 34,000 & 2,911 \\
\hline SME Nitrite, $\mathrm{mg} / \mathrm{kg}$ & 0 & 0 & \\
\hline SME Feed formate (grams) & 164.27 & 164.25 & \\
\hline SME Feed nitrate (grams) & 89.49 & 92.35 & \\
\hline SME Formate Added as acid (best basis, grams) & 7.24 & 7.24 & \\
\hline Nitrate in SME product (grams) & 80.54 & 86.09 & \\
\hline Formate in SME product (grams) & 154.36 & 153.83 & \\
\hline SME Formate Destruction (grams) & 17.15 & 17.66 & \\
\hline SME Formate Destruction (\%) planned/actual & $\mathbf{1 0 . 0}$ & $\mathbf{1 0 . 3}$ & \\
\hline SME Nitrate Destruction (grams) & 8.95 & 6.26 & \\
\hline SME Nitrate Destruction (\%) planned/actual & $\mathbf{1 0 . 0}$ & $\mathbf{6 . 8}$ & \\
\hline SME Product Formate, gmol/kg SME slurry & 1.324 & 1.350 & \\
\hline SME Product Oxalate, gmol/kg SME slurry & 0.000 & 0.000 & \\
\hline SME Product Coal, gmol/kg SME slurry & 0.000 & 0.000 & \\
\hline SME Product Nitrate, gmol/kg SME slurry & 0.501 & 0.548 & \\
\hline SME Product Nitrite, gmol/kg SME slurry & 0.000 & 0.000 & \\
\hline SME Product Manganese, gmol/kg SME slurry & 0.158 & 0.154 & \\
\hline Predicted Fe /Fe total in glass & $\mathbf{0 . 2 0 0}$ & $\mathbf{0 . 1 6 9}$ & \\
\hline
\end{tabular}




\section{Table C5 SB6-5 Checks and Balances}

\begin{tabular}{|c|c|c|}
\hline SRAT Mass Balance SB6-5 & Planned, $\mathrm{g}$ & Actual, $\mathrm{g}$ \\
\hline Sludge Simulant (grams) & $2,589.40$ & $2,589.40$ \\
\hline $\mathrm{AgNO}_{3}$ (grams) & 0.0017 & 0.0019 \\
\hline $\mathrm{HgO}($ grams $)$ & 8.5210 & 8.5226 \\
\hline $\mathrm{Pd}\left(\mathrm{NO}_{3}\right)_{2} * \mathrm{H}_{2} \mathrm{O}$ (grams solution) & 0.5444 & 0.5474 \\
\hline Coal/Carbon source (grams) & 0.0000 & 0.0000 \\
\hline $\mathrm{Rh}\left(\mathrm{NO}_{3}\right)_{3} * 2 \mathrm{H}_{2} \mathrm{O}$ (grams solution) & 2.1148 & 2.1206 \\
\hline $\mathrm{RuCl}_{3}$ (grams) & 0.9579 & 0.4546 \\
\hline Water to dilute/rinse trim chemicals (grams) & 50.00 & 50.00 \\
\hline Sodium Oxalate (grams) & 0.0000 & 0.0000 \\
\hline Total Slurry (grams) & $2,651.54$ & $2,651.05$ \\
\hline Sample Trimmed Sludge (grams) & 0.00 & 0.00 \\
\hline Slurry Mass after sample (grams) & $2,651.54$ & $2,651.05$ \\
\hline SRAT Antifoam (and water) (grams) & 42.23 & 42.25 \\
\hline Nitric Acid solution (grams) & 63.09 & 62.20 \\
\hline Formic Acid solution (grams) & 181.32 & 180.30 \\
\hline Total Dewater (grams) & 462.89 & 462.60 \\
\hline MWWT Dewater mass (grams) & & -0.36 \\
\hline SRAT FAVC Dewater mass (grams) & & 16.95 \\
\hline SRAT Sample \#1 (grams) & \multirow{9}{*}{250.00} & 14.77 \\
\hline SRAT Sample \#2 (grams) & & 15.03 \\
\hline SRAT Sample \#3 (grams) & & 13.31 \\
\hline SRAT Sample \#4 (grams) & & 15.23 \\
\hline SRAT Sample \#5 (grams) & & 1.21 \\
\hline SRAT Sample \#6 (grams) & & 1.11 \\
\hline SRAT Sample \#7 (grams) & & 15.60 \\
\hline SRAT Product Sample \#1 (grams) & & 263.19 \\
\hline SRAT Product Sample \#2 (grams) & & 75.85 \\
\hline SRAT Product after sampling (grams) & & $1,939.45$ \\
\hline SRAT Product Mass after sampling (grams) & $2,145.00$ & $1,939.45$ \\
\hline Expected Mass Loss $\left(\mathrm{CO}_{2}, \mathrm{NO}_{\mathrm{x}}\right.$, etc., $\left.\mathrm{g}\right)$ & 69.42 & 117.46 \\
\hline Anion Conversion Balance (SRAT Cycle) & Planned, g & Actual, g \\
\hline \multicolumn{3}{|l|}{ SRAT Product Analysis: } \\
\hline SRAT Product Total Solids, wt \% & 25.00 & 25.90 \\
\hline SRAT Calcined Solids, wt \% & 15.96 & 16.2 \\
\hline SRAT Mn, wt. \% calcined element & 6.98 & 6.66 \\
\hline SRAT Formate, $\mathrm{mg} / \mathrm{kg}$ & 52,268 & 52,400 \\
\hline SRAT Nitrite, mg/kg & 0 & 518 \\
\hline SRAT Nitrate, $\mathrm{mg} / \mathrm{kg}$ & 26,953 & 24,250 \\
\hline SRAT Formate Added as acid (best basis, grams) & 159.953 & 159.056 \\
\hline Nitrate Added as acid (best basis, grams) & 31.384 & 30.940 \\
\hline Nitrite in Feed (grams) & 35.15 & 35.15 \\
\hline Nitrate in Feed \& trim chemicals (grams) & 23.69 & 23.69 \\
\hline Nitrite in SRAT product (grams) & 0.00 & 1.22 \\
\hline Nitrate in SRAT product (grams) & 64.55 & 57.10 \\
\hline
\end{tabular}


SRNL-STI-2009-00413, REVISION 0

\begin{tabular}{|l|c|c|}
\hline Formate in SRAT product (grams) & 127.96 & 123.39 \\
\hline SRAT Formate Destruction (grams) & 31.991 & 35.667 \\
\hline SRAT Formate Destruction (\%) planned/actual & $\mathbf{2 0 . 0}$ & $\mathbf{2 2 . 4}$ \\
\hline SRAT Nitrite Destruction (grams) & 35.2 & 33.9 \\
\hline SRAT Nitrite Destruction (\%) & $\mathbf{1 0 0 . 0}$ & $\mathbf{9 6 . 5}$ \\
\hline Nitrite to Nitrate Conversion (grams) & 9.47 & 2.47 \\
\hline Nitrate from nitrite in SRAT product, mol & 0.153 & 0.040 \\
\hline Moles of nitrite reacted & 0.764 & 0.738 \\
\hline $\begin{array}{l}\text { \% nitrite conversion to nitrate (SRAT product } \\
\text { based) }\end{array}$ & $\mathbf{2 0 . 0}$ & $\mathbf{5 . 4}$ \\
\hline Stop at SRAT Product Redox Check: & Planned & Actual \\
\hline $\begin{array}{l}\text { Predicted SME product mass from forwarded SRAT } \\
\text { mass }\end{array}$ & 2432.8 & 2255.4 \\
\hline Predicted SME Product Formate, gmol/kg SME slurry & 1.106 & 1.001 \\
\hline Predicted SME Product Oxalate, gmol/kg SME slurry & 0.000 & 0.000 \\
\hline Predicted SME Product Coal, gmol/kg SME slurry & 0.000 & 0.000 \\
\hline Predicted SME Product Nitrate, gmol/kg SME slurry & 0.381 & 0.336 \\
\hline Predicted SME Product Nitrite, gmol/kg SME slurry & 0.000 & 0.010 \\
\hline Predicted SME Product Mn, gmol/kg SME slurry & 0.177 & 0.169 \\
\hline Predicted Fe $/$ Fe total in glass (no SME cycle) & $\mathbf{0 . 2 0 0}$ & $\mathbf{0 . 2 2 3}$ \\
\hline
\end{tabular}




\section{Table C6 SB6-6 Checks and Balances}

\begin{tabular}{|c|c|c|c|}
\hline $\begin{array}{r}\text { SRAT Mass Balance SB6-6 } \\
\end{array}$ & Planned, g & Actual, g & Delta, $g$ \\
\hline Sludge Simulant (grams) & $2,535.30$ & $2,535.30$ & 0.00 \\
\hline $\mathrm{AgNO}_{3}$ (grams) & 0.0016 & 0.0018 & 0.00 \\
\hline $\mathrm{HgO}$ (grams) & 8.3430 & 8.3488 & 0.01 \\
\hline $\mathrm{Pd}\left(\mathrm{NO}_{3}\right)_{2} * \mathrm{H}_{2} \mathrm{O}$ (grams solution) & 0.5330 & 0.5310 & 0.00 \\
\hline Coal/Carbon source (grams) & 0.0000 & 0.0000 & 0.00 \\
\hline $\mathrm{Rh}\left(\mathrm{NO}_{3}\right)_{3} * 2 \mathrm{H}_{2} \mathrm{O}$ (grams solution) & 2.0706 & 2.0932 & 0.02 \\
\hline $\mathrm{RuCl}_{3}$ (grams) & 0.9379 & 0.9378 & 0.00 \\
\hline Water to dilute/rinse trim chemicals (grams) & 50.00 & 50.00 & 0.00 \\
\hline Sodium Oxalate (grams) & 0.0000 & 0.0000 & 0.00 \\
\hline Total Slurry (grams) & $2,597.19$ & $2,597.21$ & 0.03 \\
\hline Sample Trimmed Sludge (grams) & 0.00 & 0.00 & 0.00 \\
\hline Slurry Mass after sample (grams) & $2,597.19$ & $2,597.21$ & 0.03 \\
\hline SRAT Antifoam (and water) (grams) & 41.35 & 41.35 & 0.00 \\
\hline Nitric Acid solution (grams) & 86.05 & 85.30 & -0.75 \\
\hline Formic Acid solution (grams) & 208.15 & 207.70 & -0.45 \\
\hline Total Dewater (grams) & 366.20 & 365.70 & 15.30 \\
\hline MWWT Dewater mass (grams) & & 0.20 & \\
\hline SRAT FAVC Dewater mass (grams) & & 15.60 & \\
\hline SRAT Sample \#1 (grams) & \multirow{9}{*}{250.00} & 14.69 & \multirow{9}{*}{178.86} \\
\hline SRAT Sample \#2 (grams) & & 14.54 & \\
\hline SRAT Sample \#3 (grams) & & 12.62 & \\
\hline SRAT Sample \#4 (grams) & & 16.17 & \\
\hline SRAT Sample \#5 (grams) & & 1.04 & \\
\hline SRAT Sample \#6 (grams) & & 1.03 & \\
\hline SRAT Sample \#7 (grams) & & 14.32 & \\
\hline SRAT Product Sample \#1 (grams) & & 275.68 & \\
\hline SRAT Product Sample \#2 (grams) & & 78.77 & \\
\hline SRAT Product after sampling (grams) & & $2,006.72$ & \\
\hline SRAT Product Mass after sampling (grams) & $2,232.40$ & $2,006.72$ & -225.68 \\
\hline Expected Mass Loss $\left(\mathrm{CO}_{2}, \mathrm{NO}_{\mathrm{x}}\right.$, etc., g $)$ & 73.49 & 128.80 & \\
\hline Anion Conversion Balance (SRAT Cycle) & Planned, g & Actual, g & Delta \\
\hline \multicolumn{4}{|l|}{ SRAT Product Analysis: } \\
\hline SRAT Product Total Solids, wt \% & 25.00 & 25.20 & 0.2 \\
\hline SRAT Calcined Solids, wt \% & 15.08 & 15.2 & 0.1 \\
\hline SRAT Mn, wt. \% calcined element & 6.98 & 6.52 & \\
\hline SRAT Formate, $\mathrm{mg} / \mathrm{kg}$ & 57,891 & 56,900 & -991 \\
\hline SRAT Nitrite, $\mathrm{mg} / \mathrm{kg}$ & 0 & 0 & 0 \\
\hline SRAT Nitrate, $\mathrm{mg} / \mathrm{kg}$ & 30,325 & 29,350 & -975 \\
\hline SRAT Formate Added as acid (best basis, grams) & 183.628 & 183.228 & 0 \\
\hline Nitrate Added as acid (best basis, grams) & 42.802 & 42.430 & 0 \\
\hline Nitrite in Feed (grams) & 34.42 & 34.42 & 0 \\
\hline Nitrate in Feed \& trim chemicals (grams) & 23.20 & 23.20 & 0 \\
\hline Nitrite in SRAT product (grams) & 0.00 & 0.00 & 0 \\
\hline Nitrate in SRAT product (grams) & 75.28 & 71.48 & \\
\hline
\end{tabular}


SRNL-STI-2009-00413, REVISION 0

\begin{tabular}{|l|c|c|c|}
\hline Formate in SRAT product (grams) & 146.90 & 138.58 & \\
\hline SRAT Formate Destruction (grams) & 36.726 & 44.643 & 7.9 \\
\hline SRAT Formate Destruction (\%) planned/actual & $\mathbf{2 0 . 0}$ & $\mathbf{2 4 . 4}$ & 4.4 \\
\hline SRAT Nitrite Destruction (grams) & 34.4 & 34.4 & 0.0 \\
\hline SRAT Nitrite Destruction (\%) & $\mathbf{1 0 0 . 0}$ & $\mathbf{1 0 0 . 0}$ & 0.0 \\
\hline Nitrite to Nitrate Conversion (grams) & 9.28 & 5.86 & -3.4 \\
\hline Nitrate from nitrite in SRAT product, mol & 0.150 & 0.094 & -0.06 \\
\hline Moles of nitrite reacted & 0.748 & 0.748 & 0.000 \\
\hline $\begin{array}{l}\text { \% nitrite conversion to nitrate (SRAT product } \\
\text { based) }\end{array}$ & $\mathbf{2 0 . 0}$ & $\mathbf{1 2 . 6}$ & -7.4 \\
\hline Stop at SRAT Product Redox Check: & Planned & Actual & \\
\hline $\begin{array}{l}\text { Predicted SME product mass from forwarded SRAT } \\
\text { mass }\end{array}$ & 2460.4 & 2229.7 & \\
\hline Predicted SME Product Formate, gmol/kg SME slurry & 1.250 & 1.138 & \\
\hline Predicted SME Product Oxalate, gmol/kg SME slurry & 0.000 & 0.000 & \\
\hline Predicted SME Product Coal, gmol/kg SME slurry & 0.000 & 0.000 & \\
\hline Predicted SME Product Nitrate, gmol/kg SME slurry & 0.441 & 0.426 & \\
\hline Predicted SME Product Nitrite, gmol/kg SME slurry & 0.000 & 0.000 & \\
\hline Predicted SME Product Mn, gmol/kg SME slurry & 0.172 & 0.162 & \\
\hline Predicted Fe /Fe total in glass (no SME cycle) & $\mathbf{0 . 2 0 0}$ & $\mathbf{0 . 2 0 0}$ & \\
\hline
\end{tabular}


Distribution List

$\begin{array}{ll}\text { S. L. Marra } & 773-\mathrm{A} \\ \text { A. B. Barnes } & 999-\mathrm{W} \\ \text { D. A. Crowley } & 999-\mathrm{W} \\ \text { C. C. Herman } & 999-\mathrm{W} \\ \text { N. E. Bibler } & 773-\mathrm{A} \\ \text { C. M. Jantzen } & 773-\mathrm{A} \\ \text { B. J. Giddings } & 786-5 \mathrm{~A} \\ \text { J. P. Vaughan } & 773-41 \mathrm{~A} \\ \text { S. R. Loflin } & 773-41 \mathrm{~A} \\ \text { J. M. Pareizs } & 773-\mathrm{A} \\ \text { C. J. Bannochie } & 773-42 \mathrm{~A} \\ \text { D. K. Peeler } & 999-\mathrm{W} \\ \text { M. E. Stone } & 999-\mathrm{W} \\ \text { D. C. Koopman } & 773-42 \mathrm{~A} \\ \text { B. R. Pickenheim } & 999-\mathrm{W} \\ \text { F. M. Pennebaker } & 773-42 \text { A } \\ \text { S. D. Fink } & 773-\mathrm{A} \\ \text { C. W. Gardner } & 773-\mathrm{A} \\ \text { R. H. Young } & 773-\mathrm{A} \\ \text { D. P. Lambert } & 773-\mathrm{A} \\ \text { T. L. Fellinger } & 704-26 \mathrm{~S}\end{array}$

M. T. Keefer 766-H

J. E. Occhipinti 704-S

D. C. Sherburne 704-S

R. N. Hinds 704-S

R. T. McNew 704-27S

J. W. Ray 704-S

J. F. Iaukea 704-30S

H. H. Elder 704-24S

H. B. Shah 766-H

J. M. Gillam 766-H

D. D. Larsen 766-H

B. A. Hamm 766-H

D. R. Click 773-A

B. N. Attaway 773-A

S. L. Beard 773-A

L. M. Chandler 773-A

M. J. Barnes 773-A

L. H. Connelly 773-A

C. M. Gregory 773-A

L. W. Brown 773-A

J. M. Bricker 704-27S 